Prepared for the Tennessee Valley Authority in cooperation with the University of Memphis, Center for Applied Earth Science and Engineering Research

\title{
Preliminary Evaluation of the Hydrogeology and Groundwater Quality of the Mississippi River Valley Alluvial Aquifer and Memphis Aquifer at the Tennessee Valley Authority Allen Power Plants, Memphis, Shelby County, Tennessee
}

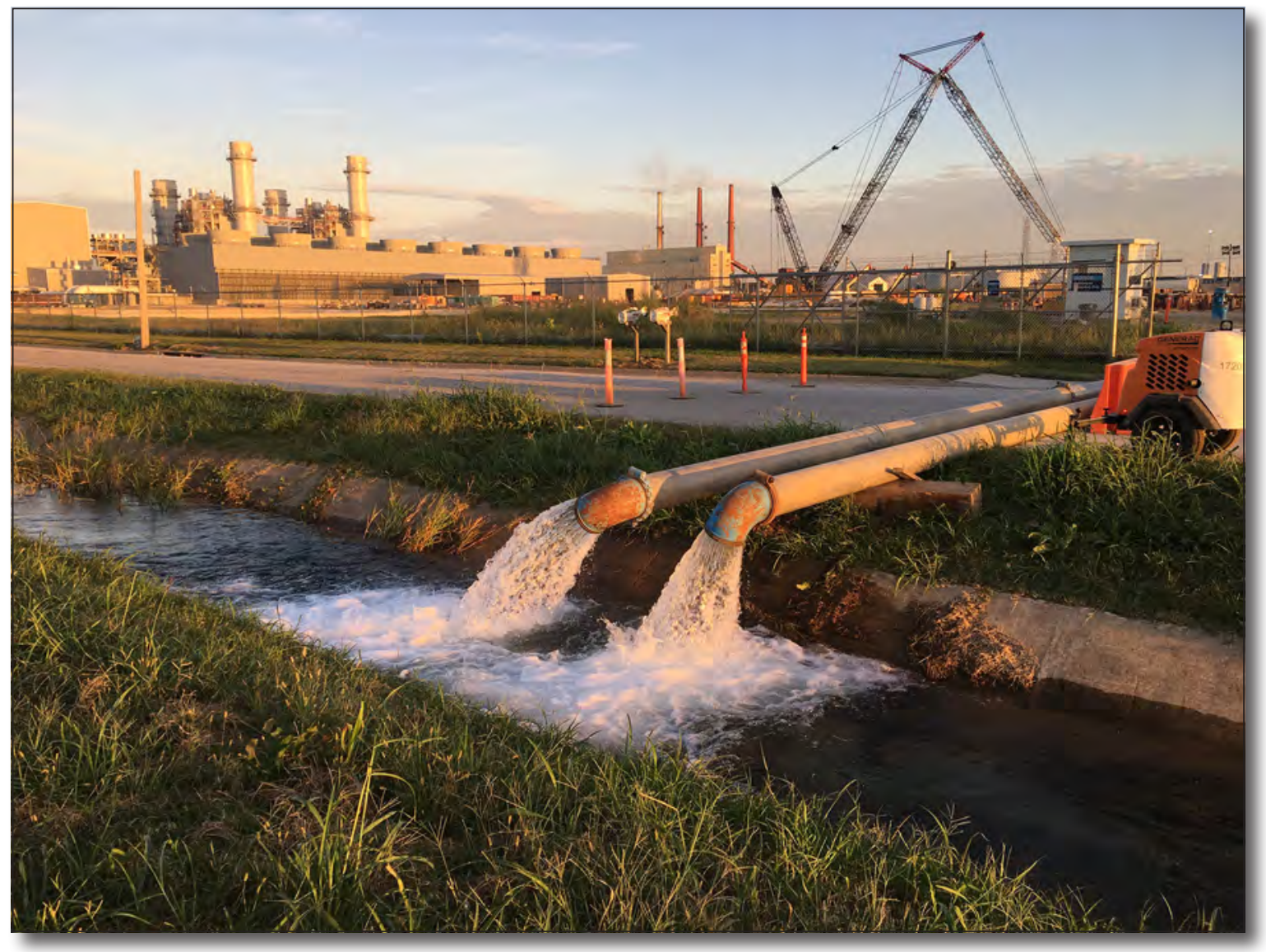

Open-File Report 2018-1097 
Cover. Groundwater discharge from an aquifer test at the Tennessee Valley Authority Allen Combined Cycle Plant in Memphis, Tennessee, October 3-4, 2017. 


\section{Preliminary Evaluation of the Hydrogeology and Groundwater Quality of the Mississippi River Valley Alluvial Aquifer and Memphis Aquifer at the Tennessee Valley Authority Allen Power Plants, Memphis, Shelby County, Tennessee}

By John K. Carmichael, James A. Kingsbury, Daniel Larsen, and Scott Schoefernacker

Prepared for the Tennessee Valley Authority in cooperation with the University of Memphis, Center for Applied Earth Science and Engineering Research

Open-File Report 2018-1097 


\section{U.S. Department of the Interior \\ RYAN K. ZINKE, Secretary}

\section{U.S. Geological Survey \\ James F. Reilly II, Director}

\section{U.S. Geological Survey, Reston, Virginia: 2018}

For more information on the USGS - the Federal source for science about the Earth, its natural and living resources, natural hazards, and the environment-visit https://www.usgs.gov or call 1-888-ASK-USGS.

For an overview of USGS information products, including maps, imagery, and publications, visit https://store.usgs.gov.

Any use of trade, firm, or product names is for descriptive purposes only and does not imply endorsement by the U.S. Government.

Although this information product, for the most part, is in the public domain, it also may contain copyrighted materials as noted in the text. Permission to reproduce copyrighted items must be secured from the copyright owner.

Suggested citation:

Carmichael, J.K., Kingsbury, J.A., Larsen, Daniel, and Schoefernacker, Scott, 2018, Preliminary evaluation of the hydrogeology and groundwater quality of the Mississippi River Valley alluvial aquifer and Memphis aquifer at the Tennessee Valley Authority Allen Power Plants, Memphis, Shelby County, Tennessee: U.S. Geological Survey Open-File Report 2018-1097, 66 p., https://doi.org/10.3133/ofr20181097.

ISSN 2331-1258 (online) 


\section{Contents}

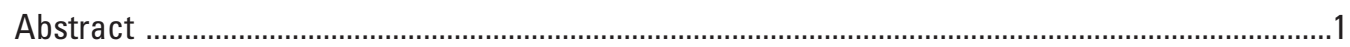

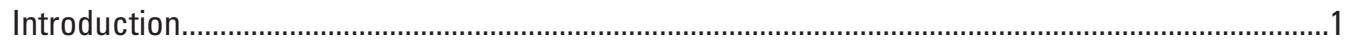

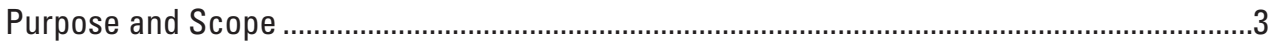

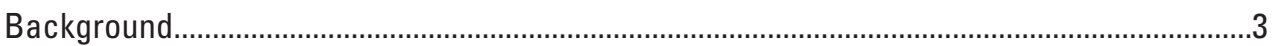

Geology and Hydrogeology of the Study Area

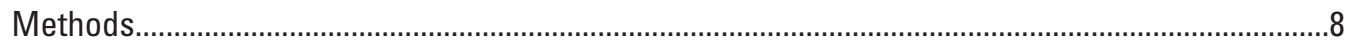

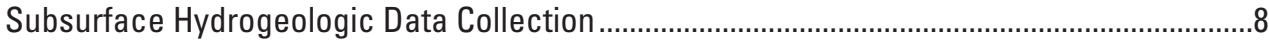

Water-Quality Sample Collection ..............................................................................................

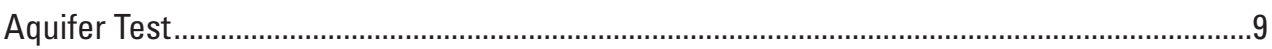

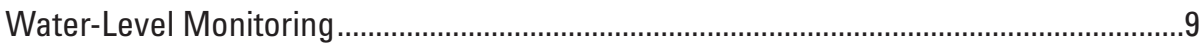

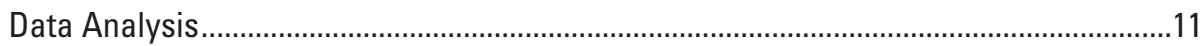

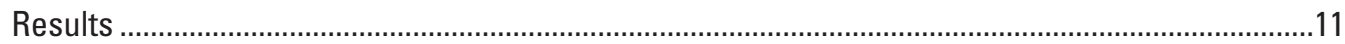

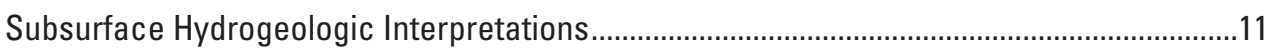

Anthropogenic Fill.....................................................................................................

Mississippi River Valley Alluvium.....................................................................................11

Upper Alluvium ...................................................................................................11

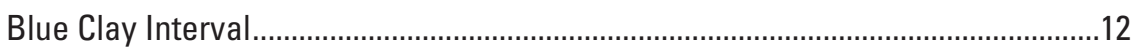

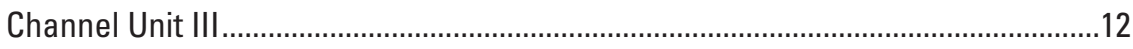

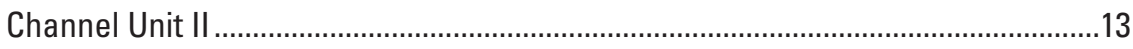

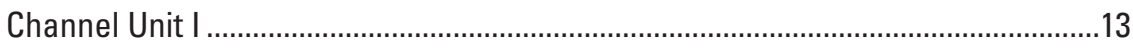

Cook Mountain Formation .....................................................................................13

Transition of Cook Mountain Formation to Memphis Sand...........................................14

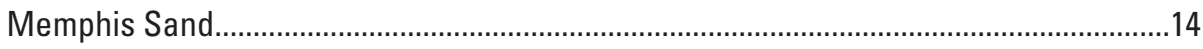

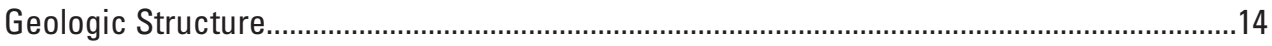

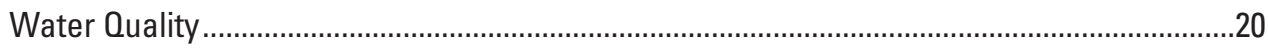

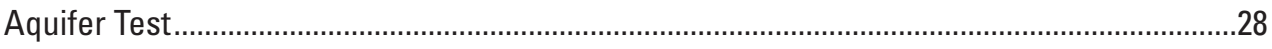

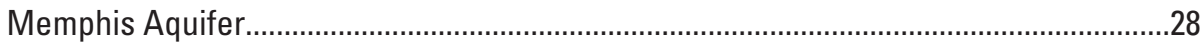

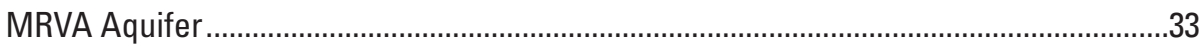

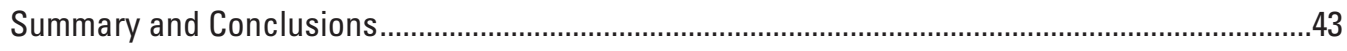

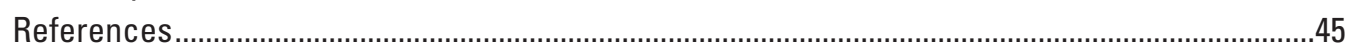

Appendix 1. SeriesSEE Water-Level Model Hydrographs-Allen Combined Cycle

Plant Monitoring Wells...................................................................................................

Appendix 2. SeriesSEE Water-Level Model Hydrographs-Allen Fossil Plant

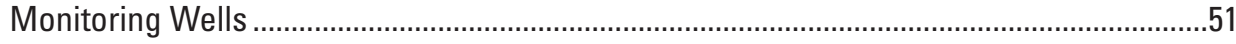

Appendix 3. SeriesSEE Water-Level Model Hydrographs-Memphis Aquifer

Observation Wells ..........................................................................................................65 


\section{Figures}

1. Maps showing locations of the Tennessee Valley Authority Allen Combined Cycle and Allen Fossil Plants in southwestern Memphis, Shelby County, Tennessee. . .2

2. Map showing locations of production wells, Memphis aquifer observation wells, and Mississippi River Valley alluvial aquifer monitoring wells used in the preliminary evaluation of the hydrogeology and groundwater conditions at the Tennessee Valley Authority Allen Combined Cycle and Allen Fossil Plants, southwest Memphis, Shelby County, Tennessee.

3. Schematic cross section showing the hydrostratigraphy of the northern Mississippi embayment east and west of Memphis, Tennessee

4. Lithologic chart showing geologic units underlying Memphis, Shelby County, Tennessee, and surrounding area.

5. Graph and table showing pumping rates, durations, and volume of water pumped for the Tennessee Valley Authority Allen Combined Cycle Plant aquifer test, October 3-4, 2017

6. Map showing locations of cross sections and inferred faults, Tennessee Valley Authority Allen Combined Cycle and Allen Fossil Plants area.....

7. Geologic section $A-A^{\prime}$, Tennessee Valley Authority Allen Combined Cycle and Allen Fossil Plants area

8. Geologic section $B-B^{\prime}$, Tennessee Valley Authority Allen Combined Cycle and Allen Fossil Plants area

9. Geologic section $C-C$, Tennessee Valley Authority Allen Combined Cycle and Allen Fossil Plants area

10. Piper diagram showing chemical characteristics of groundwater samples collected from wells at the Tennessee Valley Authority Allen Combined Cycle Plant, September 2017

11. Graph showing tritium concentrations in groundwater samples in relation to the depths of the tops of the screens for Memphis aquifer production wells at the Tennessee Valley Authority Allen Combined Cycle Plant, September 2017

12. Graphs showing hypothetical mixing line for groundwater samples collected from Memphis aquifer production wells PW 1 through PW 4 that are unaffected by leakage to production well PW 5 where alluvial water has moved into the Memphis aquifer at the Tennessee Valley Authority Allen Combined Cycle Plant, September 2017

13. Map showing maximum drawdown measured in the Memphis aquifer production wells and maximum estimated drawdown in Memphis aquifer observation wells, Tennessee Valley Authority Allen Combined Cycle Plant aquifer test, October 3-4, 2017

14. Graph showing measured drawdown and cumulative pumping rates in Memphis aquifer production wells, Tennessee Valley Authority Allen Combined Cycle Plant aquifer test, October 3-4, 2017

15. Graphs showing measured water levels and estimated drawdown in Memphis aquifer observation wells Sh:H-001, Sh:H-013, and Ar:H-002, Tennessee Valley Authority Allen Combined Cycle Plant aquifer test, October 3-4, 2017. 
16. Graphs showing measured water levels and estimated drawdown in selected Mississippi River Valley alluvial aquifer monitoring wells MW 1A, MW 3A, MW 5A and MW 5B at Allen Combined Cycle Plant; MW 202, MW 202A and MW 202B, MW 210 and MW 210A, and MW 204A and MW 204B at Allen Fossil Plant; and stage of the Mississippi River at Memphis, Tennessee Valley Authority Allen Combined Cycle Plant aquifer test, October 3-4, 2017

17. Map showing estimated drawdown in selected monitoring wells screened in the Mississippi River Valley alluvial aquifer, Tennessee Valley Authority Allen Combined Cycle Plant aquifer test, October 3-4, 2017

18. Map showing pre-test water-level altitudes in the Mississippi River alluvial aquifer and stage of Lake McKellar, Tennessee Valley Authority Allen Combined Cycle Plant aquifer test, October 3-4, 2017

19. Map showing late-pumping period water-level altitudes in the Mississippi River Valley alluvial aquifer and stage of Lake McKellar, Tennessee Valley Authority Allen Combined Cycle Plant aquifer test, 0ctober 3-4, 2017.

\section{Tables}

1. Radiocarbon ages for wood samples collected from the Mississippi River Valley alluvium at the Tennessee Valley Authority Allen Combined Cycle and Allen Fossil Plants.

2. Concentrations of major inorganic constituents and trace elements in groundwater samples collected from selected Tennessee Valley Authority Allen Combined Cycle Plant wells, September 2017.

3. Results from analyses of water-quality samples collected from selected production wells during the Allen Combined Cycle Plant aquifer test, October 3-4, 2017

4. Concentrations of tritium in groundwater samples collected from selected Allen Combined Cycle Plant wells, September and October 2017.

5. Pumping rates, drawdown values, and specific capacities for Memphis aquifer production wells during the aquifer test, 0 ctober 3-4, 2017, and from performance tests, June 15-21, 2016, Tennessee Valley Authority Allen Combined Cycle Plant........29

6. Model drawdown estimates for monitoring wells screened in the Mississippi River Valley alluvial aquifer at the Tennessee Valley Authority Allen Fossil and Allen Combined Cycle Plants, Tennessee Valley Authority Allen Combined Cycle Plant aquifer test, October 3-4, 2017 


\section{Conversion Factors}

U.S. customary units to International System of Units

\begin{tabular}{|c|c|c|}
\hline Multiply & By & To obtain \\
\hline \multicolumn{3}{|c|}{ Length } \\
\hline foot $(\mathrm{ft})$ & 0.3048 & meter $(\mathrm{m})$ \\
\hline mile (mi) & 1.609 & kilometer (km) \\
\hline \multicolumn{3}{|c|}{ Area } \\
\hline square foot $\left(\mathrm{ft}^{2}\right)$ & 929.0 & square centimeter $\left(\mathrm{cm}^{2}\right)$ \\
\hline square foot $\left(\mathrm{ft}^{2}\right)$ & 0.09290 & square meter $\left(\mathrm{m}^{2}\right)$ \\
\hline square mile $\left(\mathrm{mi}^{2}\right)$ & 259.0 & hectare (ha) \\
\hline square mile $\left(\mathrm{mi}^{2}\right)$ & 2.590 & square kilometer $\left(\mathrm{km}^{2}\right)$ \\
\hline \multicolumn{3}{|c|}{ Volume } \\
\hline gallon (gal) & 3.785 & liter $(\mathrm{L})$ \\
\hline gallon (gal) & 0.003785 & cubic meter $\left(\mathrm{m}^{3}\right)$ \\
\hline gallon (gal) & 3.785 & cubic decimeter $\left(\mathrm{dm}^{3}\right)$ \\
\hline million gallons (Mgal) & 3,785 & cubic meter $\left(\mathrm{m}^{3}\right)$ \\
\hline \multicolumn{3}{|c|}{ Flow rate } \\
\hline foot per day (ft/d) & 0.3048 & meter per day (m/d) \\
\hline gallon per minute (gal/min) & 0.06309 & liter per second (L/s) \\
\hline million gallons per day (Mgal/d) & 0.04381 & cubic meter per second (m³/s) \\
\hline \multicolumn{3}{|c|}{ Pressure } \\
\hline pound per square inch (lb/in²) & 6.895 & kilopascal (kPa) \\
\hline \multicolumn{3}{|c|}{ Radioactivity } \\
\hline picocurie per liter (pCi/L) & 0.037 & becquerel per liter $(\mathrm{Bq} / \mathrm{L})$ \\
\hline \multicolumn{3}{|c|}{ Specific capacity } \\
\hline $\begin{array}{l}\text { gallon per minute per foot ([gal/ } \\
\text { min]/ft) }\end{array}$ & 0.2070 & liter per second per meter $([\mathrm{L} / \mathrm{s}] / \mathrm{m})$ \\
\hline \multicolumn{3}{|c|}{ Hydraulic conductivity } \\
\hline foot per day (ft/d) & 0.3048 & meter per day (m/d) \\
\hline \multicolumn{3}{|c|}{ Transmissivity } \\
\hline foot squared per day ( $\left.\mathrm{ft}^{2} / \mathrm{d}\right)$ & 0.09290 & meter squared per day $\left(\mathrm{m}^{2} / \mathrm{d}\right)$ \\
\hline
\end{tabular}

Temperature in degrees Celsius $\left({ }^{\circ} \mathrm{C}\right)$ may be converted to degrees Fahrenheit $\left({ }^{\circ} \mathrm{F}\right)$ as follows:

$$
{ }^{\circ} \mathrm{F}=\left(1.8 \times{ }^{\circ} \mathrm{C}\right)+32 .
$$

Temperature in degrees Fahrenheit $\left({ }^{\circ} \mathrm{F}\right)$ may be converted to degrees Celsius $\left({ }^{\circ} \mathrm{C}\right)$ as follows:

$$
{ }^{\circ} \mathrm{C}=\left({ }^{\circ} \mathrm{F}-32\right) / 1.8 \text {. }
$$




\section{Datum}

Vertical coordinate information is referenced to the National Geodetic Vertical Datum of 1929 (NGVD 29).

Horizontal coordinate information is referenced to the North American Datum of 1983 (NAD 83).

Altitude, as used in this report, refers to distance above the vertical datum.

\section{Supplemental Information}

Specific conductance is given in microsiemens per centimeter at 25 degrees Celsius $(\mu \mathrm{S} / \mathrm{cm}$ at $\left.25^{\circ} \mathrm{C}\right)$.

Concentrations of chemical constituents in water are given in either milligrams per liter (mg/L) or micrograms per liter $(\mu \mathrm{g} / \mathrm{L})$.

\section{Abbreviations}

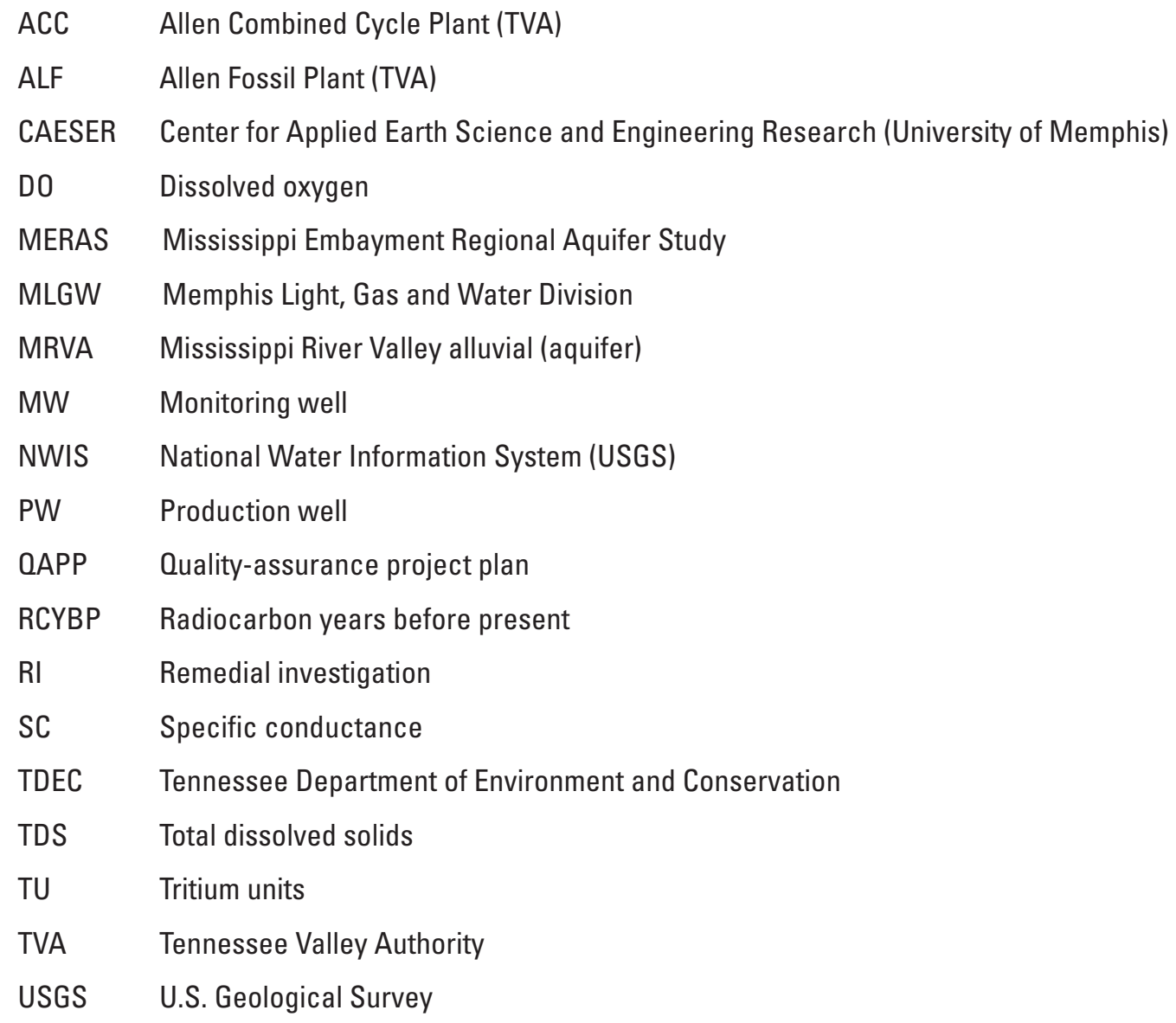





\title{
Preliminary Evaluation of the Hydrogeology and Groundwater Quality of the Mississippi River Valley Alluvial Aquifer and Memphis Aquifer at the Tennessee Valley Authority Allen Power Plants, Memphis, Shelby County, Tennessee
}

\author{
By John K. Carmichael, ' James A. Kingsbury, ${ }^{1}$ Daniel Larsen, ${ }^{2}$ and Scott Schoefernacker ${ }^{2}$
}

\section{Abstract}

The hydrogeology, groundwater quality, and potential for hydraulic connection between the Mississippi River Valley alluvial aquifer and the Memphis aquifer in the area of the Tennessee Valley Authority (TVA) Allen Combined Cycle and Allen Fossil Plants in southwestern Memphis, Tennessee, were evaluated from September through December 2017. The study was designed as a preliminary assessment of the potential for leakage of groundwater from the Mississippi River Valley alluvial aquifer through the underlying upper Claiborne confining unit into the underlying Memphis aquifer at the plants. A short-term aquifer test of four of the five Memphis aquifer production wells installed at the Allen Combined Cycle Plant induced drawdown in water levels in the Mississippi River Valley alluvial aquifer, locally. The largest drawdown occurred in the eastern and southeastern parts of the TVA plants area, and generally was coincident with locations where stratigraphic data show increased thickness of and depth to the base of the alluvium and decreased thickness and inferred offset in the base of the confining unit relative to nearby locations. In contrast, stratigraphic data for most other locations at the site indicate shallower depths to the base of the alluvium and more consistent thickness of and depth to the base of the confining unit, which corresponds with areas where less drawdown was observed during the test. Water-quality results for samples from the production wells and from monitoring wells screened in the Mississippi River Valley alluvial aquifer indicate that groundwater with higher dissolved-solids concentrations and tritium from this shallow aquifer has mixed with water in the upper part of the Memphis aquifer at one of the production wells. Results of the study collectively confirm that the Mississippi River Valley alluvial and Memphis aquifers are hydraulically connected near the TVA plants area.

\section{Introduction}

Understanding the extent and magnitude of hydraulic connection between aquifers is essential for efficient and sustainable use of groundwater resources. Key factors regarding this issue include the purposes and magnitude of groundwater use, and the contrasts in water quality and the potential connection between aquifers. In the Memphis area in Shelby County, Tennessee, large withdrawals for public and industrial supply have resulted in movement of groundwater from the shallow, "water-table” aquifers into the underlying Memphis aquifer in areas where the upper Claiborne confining unit is thin or absent (Graham and Parks, 1986; Parks, 1990). Proposed withdrawals from the Memphis aquifer at the newly constructed Tennessee Valley Authority (TVA) Allen Combined Cycle (ACC) Plant in southwestern Memphis (fig. 1) has caused public concern about the potential for degradation of the drinking-water supply. Those concerns were heightened by the identification of elevated concentrations of arsenic and other trace metals in the overlying Mississippi River Valley alluvial (MRVA) aquifer at the TVA Allen Fossil (ALF) Plant (Charlier, 2017). In 2017, the U.S. Geological Survey (USGS), in cooperation with the TVA and the University of Memphis, Center for Applied Earth Science and Engineering Research (CAESER), conducted a preliminary investigation of the hydrogeology, groundwater quality, and potential for hydraulic connection between the MRVA and Memphis aquifers in the area.

${ }^{1}$ U.S. Geological Survey.

${ }^{2}$ University of Memphis. 


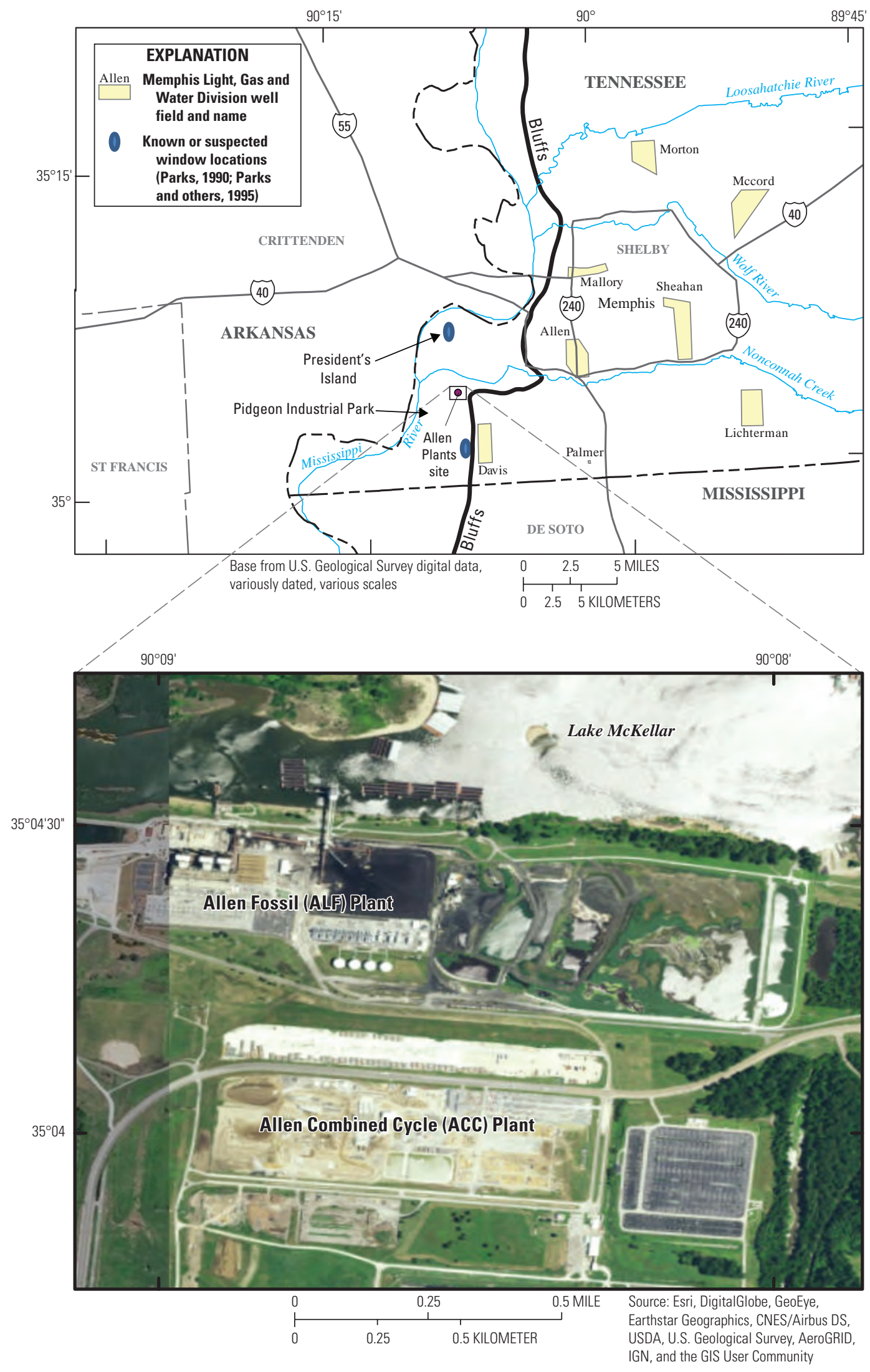

Figure 1. Locations of the Tennessee Valley Authority Allen Combined Cycle and Allen Fossil Plants in southwestern Memphis, Shelby County, Tennessee. 


\section{Purpose and Scope}

This report presents the results of a preliminary evaluation of the hydrogeology and groundwater conditions of the MRVA and Memphis aquifers at and near the TVA ALF and ACC Plants. The evaluation includes (1) interpretation of core samples and geophysical logs to assess and correlate the hydrogeologic units locally, including the extent and thickness of the confining unit separating the MRVA and Memphis aquifers; (2) characterization of water quality in the MRVA and Memphis aquifers at the TVA plants area to evaluate whether water from the MRVA aquifer has moved into the Memphis aquifer; (3) a short-term aquifer test of the Memphis aquifer production wells at the ACC Plant to determine the potential for hydraulic connection between the MRVA and Memphis aquifers; and (4) development of interpretations to support refinement of a regional conceptual model for application to the local groundwater system. All field investigations for this evaluation were conducted during September and October 2017.

\section{Background}

In 2016, the USGS produced a numerical simulation of groundwater withdrawals from proposed new production wells screened in the Memphis aquifer at the ACC Plant (Haugh, 2016). The Mississippi Embayment Regional Aquifer Study (MERAS) groundwater-flow model (Clark and Hart, 2009) was used for the simulation. The simulation scenario was designed to evaluate the effects of pumping from the Memphis aquifer at the ACC Plant for 30 years at the average expected rate of withdrawal of 2,500 gallons per minute (gal/min), followed by a 30-day period at the maximum expected rate of withdrawal of 5,000 gal $/ \mathrm{min}$. Simulated declines in the potentiometric surface of the Memphis aquifer at the plant site were 7 feet (ft) at the end of the 30-year average withdrawal period and $11 \mathrm{ft}$ at the end of the scenario. Simulated declines in the underlying Fort Pillow aquifer and overlying MRVA aquifer were less than $1 \mathrm{ft}$ at the end of the 30-year average period and at the end of the scenario. Based on the results of the simulation, TVA decided to install wells in the Memphis aquifer to supply process water for the ACC Plant.

In 2017, following installation of five Memphis aquifer production wells at the ACC Plant (fig. 2), groundwater samples collected from two MRVA aquifer monitoring wells at the ALF Plant, located north of the ACC Plant (fig. 2), contained elevated levels of arsenic and other trace metals
(Charlier, 2017). Subsequently, concerns were raised by the Tennessee Department of Environment and Conservation (TDEC) as to whether operation of the Memphis aquifer production wells at the ACC Plant could potentially cause downward movement of groundwater and contaminants from the overlying MRVA aquifer at the ALF Plant. Because of these concerns, TDEC requested that the TVA conduct a Remedial Investigation (RI) of the nature and extent of contamination in the MRVA aquifer, including the potential for contaminant migration to the Memphis aquifer. TVA retained Stantec Consulting Services Inc. (Stantec) to conduct the RI.

A major factor contributing to questions about the potential for downward leakage of groundwater from the MRVA aquifer to the Memphis aquifer stems from an inferred breach or "window" in the clay confining unit that separates the two aquifers beneath President's Island (fig. 1), north of the TVA plants area (Parks, 1990). Here, clay-rich units of the upper Claiborne Group (fig. 3) that make up the upper Claiborne confining unit have been inferred to be sandy, thin, or absent (0 thickness), creating a potential for exchange of water between the two aquifers. A window has been identified at the south end of the Pidgeon Industrial Park (fig. 1), about 3 miles (mi) south of the TVA plants area and west of the Memphis Light, Gas and Water Division (MLGW) Davis well field where downward leakage of water from the MRVA to the Memphis aquifer has been documented (Parks and others, 1995; Koban and others, 2011). Several other locations in the Memphis area have been identified where leakage of water from the shallow, "water-table" (alluvial and [or] fluvial deposits) aquifers to the Memphis aquifer occurs. Most of these locations were identified based on variations in thickness of clay that makes up the upper Claiborne confining unit, local declines in water levels in the shallow aquifers near locations of withdrawal from the Memphis aquifer, changes in water-quality characteristics in the Memphis aquifer related to groundwater withdrawals, and (or) results of hydrologic tracer studies, all of which indicate movement of water from the shallow aquifers to the Memphis aquifer (Criner and others, 1964; Bell and Nyman, 1968; Parks and Lounsbury, 1976; Graham and Parks, 1986; Parks and Mirecki, 1992; Larsen and others, 2003; Gentry and others, 2005; Gentry and others, 2006; Ivey and others, 2008; Larsen and others, 2013; Larsen and others, 2016). Because of the proximity of known or inferred areas of leakage near the power plants, the TVA requested that the USGS and CAESER jointly conduct a study to evaluate the hydrogeology and groundwater conditions at the TVA plants site, with focus on the potential for hydraulic connection between the MRVA and Memphis aquifers. 
$90^{\circ} 12^{\prime}$

$90^{\circ} 08^{\prime}$

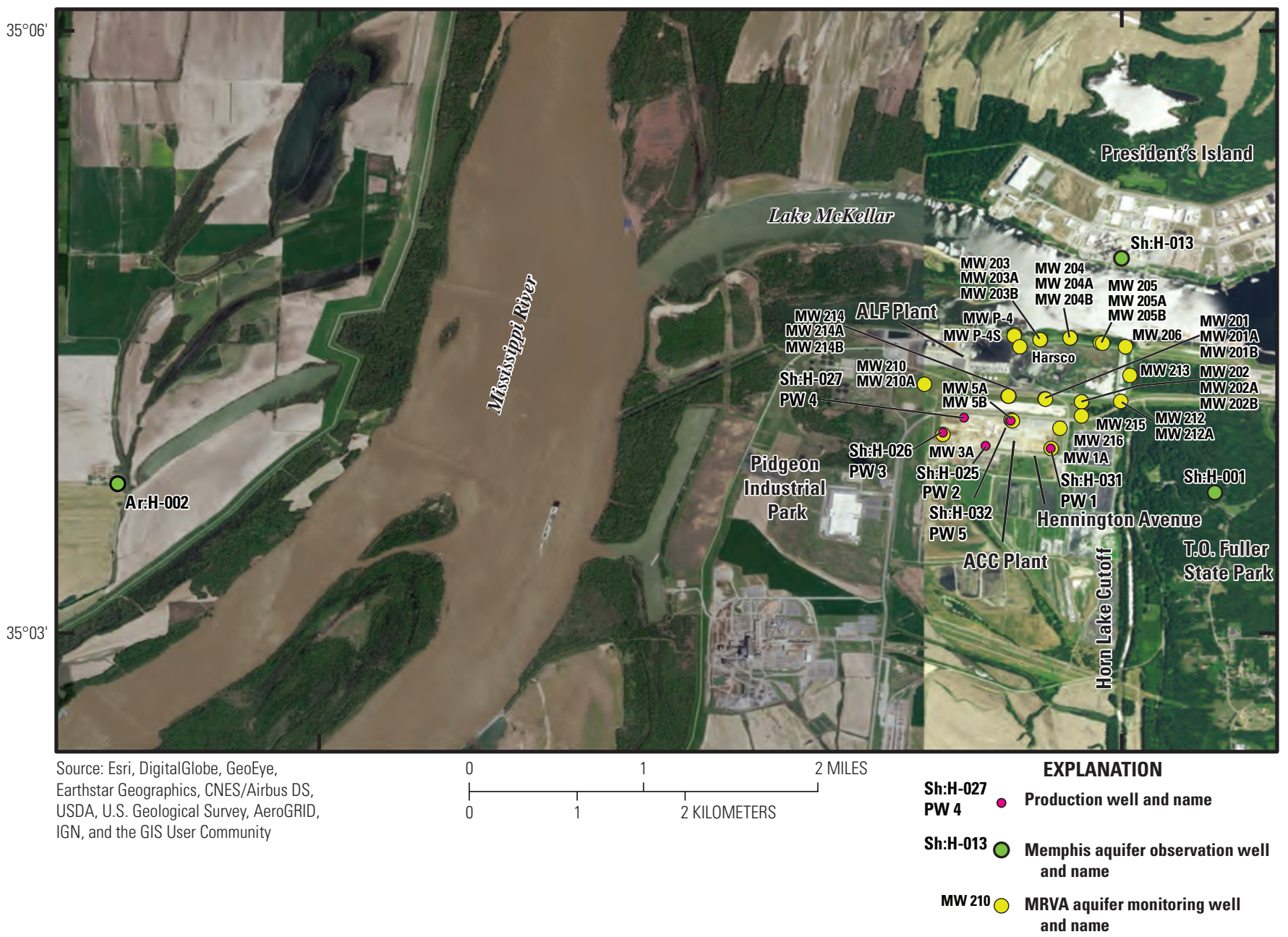

Figure 2. Locations of production wells, Memphis aquifer observation wells, and Mississippi River Valley alluvial aquifer monitoring wells used in the preliminary evaluation of the hydrogeology and groundwater conditions at the Tennessee Valley Authority Allen Combined Cycle and Allen Fossil Plants, southwest Memphis, Shelby County, Tennessee. 


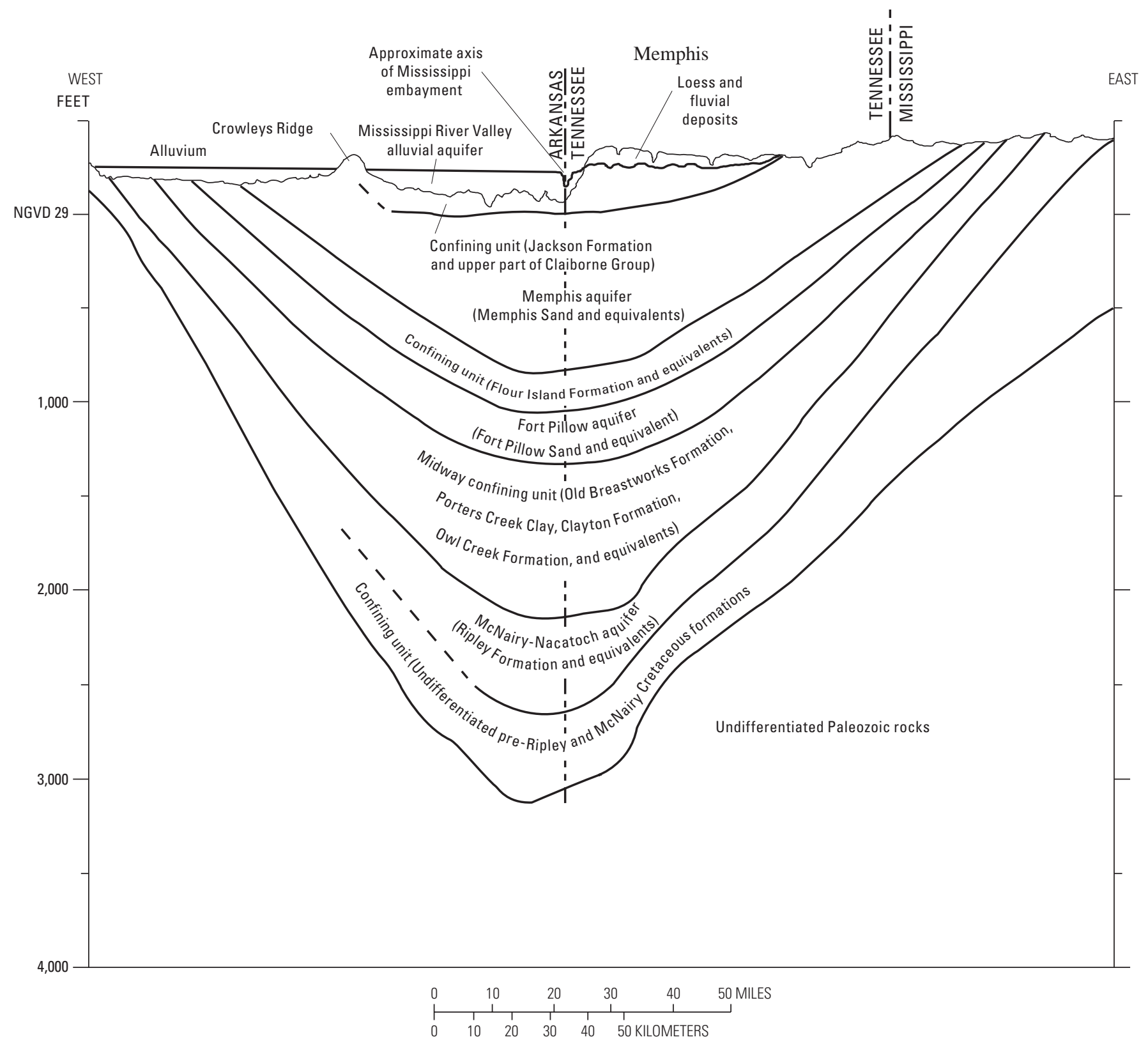

Figure 3. Schematic cross section showing the hydrostratigraphy of the northern Mississippi embayment east and west of Memphis, Tennessee. 


\section{Geology and Hydrogeology of the Study Area}

The TVA ALF and ACC Plants are located in the Mississippi River Valley within the northern Mississippi embayment. Numerous investigations have been conducted in the past regarding the geology and hydrogeology of the Memphis and Shelby County, Tennessee, area. The general geology and hydrogeology of the area and of the hydrostratigraphic units present in in the TVA study area are briefly described below to provide context for the site-specific investigation at the TVA plants site.

Memphis and Shelby County lie in the center of the northern Mississippi embayment, a trough-shaped basin that plunges southward along an axis that approximately overlies the Mississippi River (fig. 3). The Mississippi embayment is filled with more than $3,000 \mathrm{ft}$ of sediments of Cretaceous, Tertiary, and Quaternary age (Moore and Brown, 1969; Brahana and Broshears, 2001). The upper-Cretaceous- through middle-Tertiary-age geologic units beneath Shelby County dip to the west and include unconsolidated sand, silt, and clay with minor lignite. The Tertiary and older units form the Mississippi embayment aquifer system, a system of aquifers and confining units that are important sources of water for most uses in the Mississippi embayment (Lloyd and Lyke, 1995). Loess (windblown silt and clay) of Pleistocene age and fluvial (terrace) deposits primarily composed of sand and gravel deposits of Pliocene(?) and Pleistocene age mantle the middle Tertiary units in the upland parts of the Memphis area outside the Mississippi River Valley alluvial plain and the alluvial plains of the major tributaries that drain the area. Alluvium of Holocene age makes up the surficial unit in the Mississippi River alluvial valley and the present-day valleys of the primary streams in the Memphis area. The alluvium in the Mississippi River alluvial valley makes up the MRVA aquifer, an important regional aquifer in the Mississippi embayment (Lloyd and Lyke, 1995).

In the TVA plants area, the hydrogeologic units that are present and of importance to this evaluation are, in descending order, the MRVA aquifer, the upper Claiborne confining unit, and the Memphis aquifer (figs. 3 and 4). Loess and fluvial deposits underlie the Mississippi River bluffs area to the southeast of the TVA plants site (fig. 1). These units were not investigated during the evaluation.

The Mississippi River Valley alluvium in the Memphis area consists primarily of sand, gravel, silt, and clay in the upper parts and sand and gravel in the lower parts. The alluvium ranges from 0 to about $200 \mathrm{ft}$ in thickness in the Memphis area, but commonly is 100 to $150 \mathrm{ft}$ thick (Parks, 1990). Horizontal hydraulic conductivity of the MRVA aquifer ranges from 90 to 390 feet per day (ft/d), with a geometric mean range of 205 to $210 \mathrm{ft} / \mathrm{d}$ (Krinitzsky and Wire, 1964; Newcome, 1971; Ackerman, 1996).

The Cockfield and Cook Mountain Formations are the uppermost Tertiary units in the Memphis area and are composed predominantly of clay, silt, and fine sand. The thicknesses of the Cockfield and Cook Mountain Formations in the Memphis area range from 0 to $250 \mathrm{ft}$ and 0 to $110 \mathrm{ft}$, respectively (Kingsbury and Parks, 1993). The Cockfield and Cook Mountain Formations are the primary components of the upper Claiborne confining unit, which is the lower confining unit for the shallow aquifers and upper confining unit for the Memphis aquifer in the Memphis area (figs. 3 and 4). The thickness of the upper Claiborne confining unit varies within Shelby County from about $375 \mathrm{ft}$ in northwestern Shelby County to $0 \mathrm{ft}$ in the southeastern part of the county (Parks, 1990). Although fine-grained strata constitute much of both formations, the Cook Mountain Formation is the most persistent clay layer in the upper Claiborne confining unit in the Memphis area (Parks, 1990). An aquifer is present locally in the Cockfield Formation in Millington in the northern part of Shelby County (Robinson and others, 1997) and in other locations in West Tennessee (Parks and Carmichael, 1990b). The Cockfield Formation is absent or has only limited thickness beneath the Mississippi River alluvial plain; at the TVA plants site, the Cook Mountain Formation is the primary component of the upper Claiborne confining unit. Slug and single-well aquifer tests in wells screened in the upper Claiborne confining unit at a site in the eastern part of Memphis yielded horizontal hydraulic conductivity values of $2.0 \times 10^{-5}$ to $5.0 \times 10^{-5} \mathrm{ft} / \mathrm{d}$ (Gentry and others, 2006). Vertical hydraulic conductivity values for clay samples collected from the upper Claiborne confining unit near Millington, Tennessee, ranged from $5.0 \times 10^{-6}$ to $2.5 \times 10^{-3} \mathrm{ft} / \mathrm{d}$ (Robinson and others, 1997). The thickness of clay beds in the confining unit is as much as $250 \mathrm{ft}$ in the Memphis area but thins to $0 \mathrm{ft}$ at some locations (Parks, 1990), suggesting that hydrologic connectivity exists between the underlying Memphis aquifer and the overlying shallow aquifers where the clay beds are thin or absent.

The Memphis aquifer is a thick, sand-dominated aquifer, ranging in thickness from about 650 to $900 \mathrm{ft}$ in the Memphis area (Kingsbury and Parks, 1993). Lenses of clay and silt are present in the aquifer at various horizons (Parks, 1990). The test hole for production well PW 4 at the ACC Plant penetrated the full thickness of the Memphis aquifer; thickness at this location was about $840 \mathrm{ft}$. Based on results from about 60 aquifer tests in the Memphis area, transmissivities range from about 6,700 to 53,500 feet squared per day ( $\left.\mathrm{ft}^{2} / \mathrm{d}\right)$, with an average of 33,400 ft $2 / \mathrm{d}$, and storativity (storage coefficients) values range from 0.0001 to 0.003 for the Memphis aquifer (Parks and Carmichael, 1990a). Assuming an average thickness of $700 \mathrm{ft}$ for the Memphis aquifer in the Memphis area, the average hydraulic conductivity based on the average transmissivity from the tests is about $48 \mathrm{ft} / \mathrm{d}$. The Memphis aquifer is the primary source of water for all uses at Memphis and throughout most of West Tennessee. Average withdrawals from the Memphis aquifer for public-water supply in Shelby County were reported at 187 million gallons per day (Mgal/d) in 2005 (Robinson and Brooks, 2010). 


\begin{tabular}{|c|c|c|c|c|c|}
\hline System and series & Group & $\begin{array}{c}\text { Stratigraphic } \\
\text { unit }\end{array}$ & $\begin{array}{l}\text { Hydrostratigraphic } \\
\text { unit }\end{array}$ & $\begin{array}{c}\text { Thickness } \\
\text { (feet) }\end{array}$ & Lithology and hydrologic significance \\
\hline $\begin{array}{l}\text { Quaternary } \\
\text { Holocene } \\
\text { and } \\
\text { Pleistocene }\end{array}$ & & Alluvium & Alluvial aquifer & $0-200$ & $\begin{array}{l}\text { Sand and gravel that grades upward to silt and clay. } \\
\text { Underlies the Mississippi River alluvial plain and } \\
\text { alluvial plains of tributary streams in West Tennes- } \\
\text { see. Thickness beneath the Mississippi River al- } \\
\text { luvial plain is as much as } 230 \text { feet; generally, less } \\
\text { than } 50 \text { feet thick in tributary valleys. Provides } \\
\text { water to domestic, farm, industrial, and irrigation } \\
\text { wells in the Mississippi alluvial plain. }\end{array}$ \\
\hline $\begin{array}{l}\text { Quaternary } \\
\text { Pleistocene }\end{array}$ & & Loess & $\begin{array}{l}\text { Leaky confining } \\
\text { layer }\end{array}$ & $0-65$ & $\begin{array}{l}\text { Silt, silty clay, and minor sand. Principal unit at } \\
\text { the surface in upland areas of the Mississippi } \\
\text { embayment. Thickest on the bluffs that border the } \\
\text { Mississippi alluvial plain; thinner and finer grained } \\
\text { eastward from the bluffs. Tends to retard down- } \\
\text { ward percolation of water recharging the fluvial } \\
\text { deposits aquifer. }\end{array}$ \\
\hline Tertiary & Claiborne & $\begin{array}{l}\text { Upper part of } \\
\text { Claiborne } \\
\text { Group, in- } \\
\text { cludes Cock- } \\
\text { field and Cook } \\
\text { Mountain } \\
\text { Formations } \\
\text { (capping clay) }\end{array}$ & $\begin{array}{l}\text { Upper Claiborne } \\
\text { confining unit }\end{array}$ & $0-360$ & $\begin{array}{l}\text { Clay, silt, sand, and lignite. The Cook Mountain } \\
\text { Formation is mainly silt and clay with minor fine- } \\
\text { grained sand and rare lignite beds. The Cockfield } \\
\text { Formation comprises fine-grained sand that com- } \\
\text { monly grades upward to silt and clay with com- } \\
\text { mon lignite beds. The Cook Mountain Formation } \\
\text { serves as the primary upper confining unit for the } \\
\text { Memphis aquifer. Saturated sands in the Cockfield } \\
\text { Formation locally serve as aquifers in western } \\
\text { Tennessee. }\end{array}$ \\
\hline \multirow{3}{*}{ Paleocene } & \multirow[t]{3}{*}{ Wilcox } & $\begin{array}{l}\text { Flour Island } \\
\text { Formation }\end{array}$ & $\begin{array}{l}\text { Flour Island con- } \\
\text { fining unit }\end{array}$ & $140-310$ & $\begin{array}{l}\text { Clay, silt, sand, and lignite. Consists primarily of } \\
\text { silty clay and sandy silt with lenses of fine sand } \\
\text { and lignite. Serves as the lower confining bed for } \\
\text { the Memphis aquifer and the upper confining bed } \\
\text { for the Fort Pillow aquifer. }\end{array}$ \\
\hline & & $\begin{array}{l}\text { Fort Pillow Sand } \\
\text { (" } 1,400 \text {-foot" } \\
\text { sand) }\end{array}$ & Fort Pillow aquifer & $98-300$ & $\begin{array}{l}\text { Sand with minor clay and lignite. Sand is fine to } \\
\text { medium. Thickest in the southwestern part of the } \\
\text { Memphis area; thinnest in the northern and north- } \\
\text { eastern parts. Second principal aquifer supplying } \\
\text { water to the City of Memphis and some industry. } \\
\text { Principal aquifer providing water for municipal and } \\
\text { industrial supplies west of the Mississippi River. }\end{array}$ \\
\hline & & $\begin{array}{l}\text { Old Breastworks } \\
\text { Formation }\end{array}$ & $\begin{array}{l}\text { Old Breastworks } \\
\text { confining unit }\end{array}$ & $180-310$ & $\begin{array}{l}\text { Clay, silt, sand, and lignite. Consists primarily of } \\
\text { silty clay and clayey silt with lenses of fine sand } \\
\text { and lignite. Serves as the lower confining bed for } \\
\text { the Fort Pillow aquifer, along with the underlying } \\
\text { Porters Creek Clay. }\end{array}$ \\
\hline
\end{tabular}

Figure 4. Geologic units underlying Memphis, Shelby County, Tennessee, and surrounding area (from Graham and Parks, 1986; Parks, 1990; Kingsbury and Parks, 1993). 


\section{Methods}

The preliminary evaluation of the hydrogeology, groundwater quality, and potential for hydraulic connection between the MRVA and Memphis aquifers at the TVA plants site consisted of three main components of work: subsurface hydrogeologic data collection and interpretation; collection of groundwater samples from selected MRVA and Memphis aquifer wells at the ACC Plant for analyses of major inorganic constituents, trace metals, and tritium; and a short-term aquifer test to evaluate hydraulic connection between the MRVA and Memphis aquifers.

\section{Subsurface Hydrogeologic Data Collection}

To better understand the local hydrogeology at the ACC and ALF Plants, the USGS and CAESER assisted the TVA and Stantec in data collection during the installation of monitoring wells in the MRVA aquifer and drilling of four deep stratigraphic test holes into the top of the Memphis aquifer in September 2017 as part of the RI at the ALF Plant. Prior to September 2017, a network of monitoring wells was in place at the ALF Plant, with most wells screened in the upper part of the MRVA aquifer ("shallow" wells designated with "200" series numbers [for example, MW 203], and well MW P-2 which was not used for this study), and two wells screened in the middle part of the aquifer, only one of which was used for this study (well MW P-4) (fig. 2). In September 2017, the network was expanded by the installation of additional monitoring wells at locations at both TVA plants. The new wells were drilled and continuously cored using rotasonic methods into deeper parts of the MRVA aquifer. The new monitoring wells are screened in the middle (or intermediate) parts (wells designated with a "B" [for example, MW 203B and MW 5B]) and lower (or deep) parts (wells designated with an "A" [for example, MW 203A and MW 5A]) (fig. 2) of the MRVA aquifer. An additional shallow monitoring well (MW P-4S) also was installed with a screened interval in the upper part of the MRVA aquifer as part of the drilling work at the location of monitoring well MW P-4 (fig. 2). During the drilling program, the four stratigraphic test holes (designated by adding " $\mathrm{c}$ " to existing monitoring well series location numbers [205c, 212c, 214c, and P-4c]) were drilled into the upper part of the Memphis aquifer to determine the thickness of the confining unit and the altitude of the top of the Memphis Sand at selected locations at the ALF Plant. Natural gamma-ray geophysical logs were made in these test holes before they were filled and abandoned. Geophysical logs and core samples from the four test holes and core samples from borings for selected monitoring wells screened in the lower part of the MRVA aquifer were used along with geophysical logs made in the five Memphis aquifer production wells installed at the ACC Plant for stratigraphic correlation of the contacts between the base of the MRVA aquifer and top of the upper Claiborne confining unit, and the base of the confining unit and the top of the Memphis Sand at the TVA plants site. In addition, geophysical logs from two nearby offsite wells screened in the Memphis aquifer (fig. 2; Sh:H-001 and Sh:H-013) were used to aid in correlating the stratigraphy in the TVA plants area.

Cuttings from selected borings for monitoring wells (MW 1A, MW 3A, MW 5B, and MW 216) and the stratigraphic test holes (205c, 212c, 214c, and P-4c) were described in the field. Analysis of the drilling core samples included visual inspection of grain size and composition and characterization of fines (silt and clay), sedimentary structures, and other features useful for correlating the borehole strata to regional stratigraphic units and interpreting the sedimentary depositional environments. Samples of wood were collected from the cores at different depths in the MRVA aquifer in stratigraphic test holes 205c, 212c, and 214c and from the borings for monitoring wells MW 1A and MW 5B for carbon-14 $\left({ }^{14} \mathrm{C}\right)$ analysis to identify intervals of sediment of similar age from site to site. The wood samples were submitted to the University of Arizona Accelerator Mass Spectrometer Laboratory in Tucson, Arizona, for analysis.

\section{Water-Quality Sample Collection}

In September 2017, the USGS, CAESER, and Stantec collected groundwater samples from the five Memphis aquifer production wells (PW 1 through $\mathrm{PW}$ 5) and five monitoring wells (MW 1A, MW 3A, MW 5A, MW 5B, and MW 216) at the ACC Plant. Water samples were analyzed onsite for temperature, dissolved oxygen (DO), $\mathrm{pH}$, and specific conductance (SC). Filtered and unfiltered samples were collected for laboratory analyses of major inorganic constituents (ions), trace elements, and tritium. Major inorganic constituents and trace elements analyses were completed at the USGS National Water Quality Laboratory in Denver, Colorado. Samples were analyzed for tritium at the University of Miami Tritium Laboratory in Miami, Florida. Water-quality data collected by the USGS as part of this study are provided in this report and are publicly available through the USGS National Water Information System (NWIS; U.S. Geological Survey, 2018).

Samples from the production wells were collected after the turbine pumps were run for a minimum of 30 minutes and field parameters (temperature, $\mathrm{SC}, \mathrm{pH}, \mathrm{DO}$, and turbidity) were stable. Monitoring wells were purged and sampled using a stainless-steel bladder pump and low-flow sampling techniques, and samples were collected when field parameters were stable. Sampling equipment that was reused, such as the bladder pump, was cleaned between wells with a soap wash and tap- and deionized-water rinse. Tubing used for sampling at all of the wells was single use. Samples were filtered with disposable 0.45 -micron capsule filters. Alkalinity was measured in the field by titration.

Additional groundwater samples were collected by the CAESER from four of the five production wells (PW1, 
PW3, PW4, and PW5) at the ACC Plant during the aquifer test in October 2017. The samples were analyzed for selected dissolved major anions at the University of Memphis, and for tritium at the University of Miami Laboratory. Water-quality data collected and analyzed by the CAESER as part of this study are provided in this report.

\section{Aquifer Test}

A 24-hour aquifer test of four of the five Memphis aquifer production wells at the ACC Plant was conducted during October 3-4, 2017. The purpose of the test was to evaluate drawdown in the Memphis aquifer and the potential for hydraulic connection between the Memphis and MRVA aquifers local to the ACC and ALF Plants. The pumping scenario consisted of a step test with a maximum production rate of 5,000 gal/min designed to simulate groundwater withdrawals at the ACC Plant for an extremely hot summer day in which an estimated 5.4 Mgal of water would be needed to meet local power demands. Water levels were measured in the ACC Plant production wells to determine the maximum drawdown for each pumping step and rate of water-level recovery in the Memphis aquifer following pumping cessation. Water levels also were monitored in three offsite Memphis aquifer observation wells to evaluate the magnitude and extent of drawdown in the aquifer from the test. To evaluate hydraulic connection between the Memphis aquifer and the MRVA aquifer, water levels were monitored in selected network monitoring wells screened in the MRVA aquifer across the TVA plants site (fig. 2). No substantial rainfall occurred in the Memphis area from October 1 through the end of the test.

The aquifer test began at 10:00 a.m. on Tuesday, October 3, 2017, and ended at 10:00 a.m. on Wednesday, October 4, 2017. The test comprised three pumping steps, starting with two production wells (PW 1 and PW 5) pumping for 8 hours, followed by the addition of a third well (PW 3) pumping for the second 8 hours, and ending with the addition of a fourth well (PW 4) pumping for the last 8 hours (fig. 5). Production well PW 2 was not pumped and served as an onsite observation well during the test. Prior to the start of the test, a 5- to 30-minute pre-test (fig. 5) of the production wells was conducted in a stepped sequence similar to that of the planned test to evaluate the temporary piping, pump controls, and discharge point. Discharge from the wells was routed by temporary piping from the permanent production well discharge points at the ACC Plant cooling tower basin to a large concrete-lined stormwater ditch along Hennington Avenue that drains eastward along the southern side of the ACC Plant and empties into the Horn Lake Cutoff southeast of the ACC Plant (fig. 2).

\section{Water-Level Monitoring}

Airline water-level measurements were made in the four pumping production wells and in the one nonpumped production well during the test. Each production well is equipped with an analog pressure gage attached to the upper end of a small-diameter copper-tube airline that displays in units of pounds per square inch and feet of water. Airline water-level readings were accurate to approximately $+1 \mathrm{ft}$ ( +0.4 pound per square inch). All readings were recorded on field sheets specific for each well. Periodic measurements of static water levels were made in each well starting on October 2 and prior to the pre-test pumping on the morning of October 3. Measurements also were made in each well during and immediately following the pre-test to determine response to this short-duration pumping and how quickly water levels recovered to static conditions prior to start of the aquifer test (water levels in all wells recovered to static levels based on the accuracy of air-line readings). Once the test started, periodic water-level measurements were made in all wells at maximum time intervals of 1 hour. Measurements were made more frequently during the early time of each pumping step when drawdown rates were greatest and less frequently as drawdowns began to stabilize. Water-level measurements continued to be made in each well for approximately 2 hours after the pumps were turned off or until water levels recovered to within about 90 percent of pre-pumping levels. Final measurements were made in each production well during midmorning on October 5, 2017.

Three offsite Memphis aquifer observation wells were monitored during the test (fig. 2): well Ar:H-002 (USGS 350344090130000) located in Crittenden County, Arkansas, about 4 mi west of the ACC Plant; well Sh:H-001 (USGS 350342090073201) located at T.O. Fuller State Park, about 0.75 mi east-southeast of the ACC Plant; and well Sh:H-013 (USGS 350452090075901) located at the Cargill Memphis Plant on President's Island, about 1 mi north-northeast of the ACC Plant. Absolute (nonvented) pressure transducers were deployed in these wells to collect water-level data at 5-minute intervals for several days prior to, during, and several days following the test. In addition, a few periodic measurements were made using either a steel tape and chalk or an electric tape in wells Sh:H-001 and Sh:H-013 to verify the continuous data collected from these wells during the test. The transducers were retrieved from the wells several days following the test, and the raw data were downloaded and compensated for barometric pressure using data recorded by a transducer deployed at land surface in well Sh:H-001.

A subset of the network of monitoring wells located at the ALF and ACC Plants was used for evaluating water levels in the MRVA aquifer during the test. The subset included 27 wells at the ALF Plant and the 5 wells at the ACC Plant (fig. 2). Absolute 


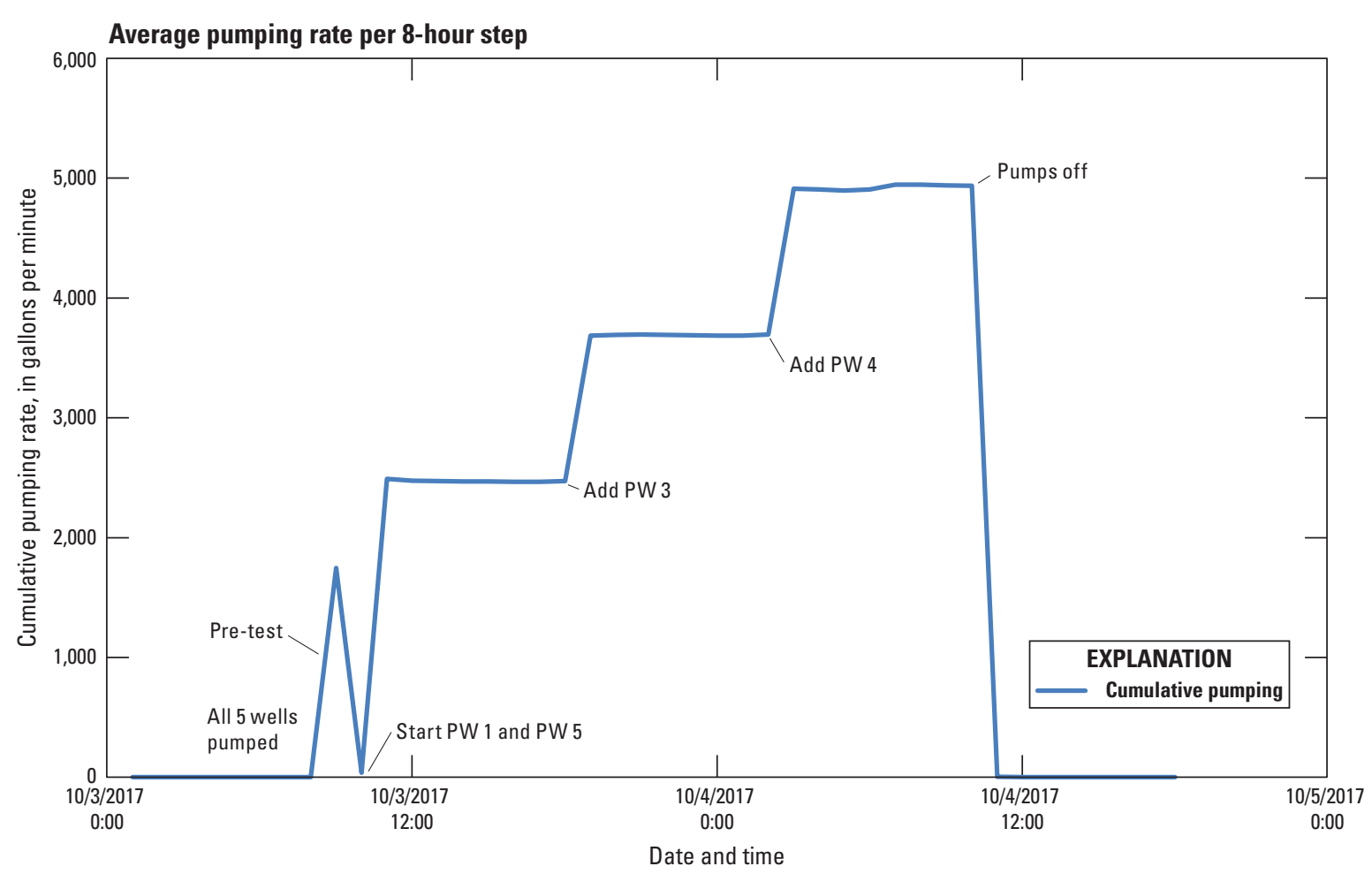

\begin{tabular}{|c|c|c|c|c|c|c|}
\hline $\begin{array}{l}\text { Start/step } \\
\text { times* }\end{array}$ & $\begin{array}{l}\text { Step/finish } \\
\text { times* }\end{array}$ & $\begin{array}{c}\text { Duration, } \\
\text { hours }\end{array}$ & $\begin{array}{l}\text { Flow rate, } \\
\text { in gallons } \\
\text { per minute }\end{array}$ & $\begin{array}{l}\text { Production } \\
\text { wells }\end{array}$ & $\begin{array}{l}\text { Water volume, } \\
\text { million gallons }\end{array}$ & \\
\hline $\begin{array}{l}\text { Start 10:00 am } \\
\text { October } 3\end{array}$ & $6: 00 \mathrm{pm}$ & 8 & 2,500 & 1,5 & 1.2 & \\
\hline $6: 00 \mathrm{pm}$ & $2: 00 \mathrm{am}$ & 8 & 3,750 & $1,5,+3$ & 1.8 & \\
\hline $2: 00 \mathrm{am}$ & $\begin{array}{c}\text { Finish 10:00 am } \\
\text { October } 4\end{array}$ & 8 & 5,000 & $1,5,3,+4$ & 2.4 & \\
\hline Total & & & & & 5.4 & \\
\hline \multicolumn{7}{|c|}{$\begin{array}{l}\text { *Note: Production well PW } 2 \text { was not pumped and served as an observation well/emergency } \\
\text { backup well during test }\end{array}$} \\
\hline $\begin{array}{c}\text { PW } 1 \\
1,790,189\end{array}$ & $\begin{array}{l}\text { PW } 2 \\
4,903\end{array}$ & \multicolumn{2}{|c|}{$\begin{array}{c}\text { PW } 3 \\
1,199,572\end{array}$} & $\begin{array}{c}\text { PW } 4 \\
616,140\end{array}$ & $\begin{array}{c}\text { PW } 5 \\
1,817,733\end{array}$ & $\begin{array}{c}\text { Total } \\
5,428,537\end{array}$ \\
\hline
\end{tabular}

Figure 5. Pumping rates, durations, and volume of water pumped for the Tennessee Valley Authority Allen Combined Cycle Plant aquifer test, October 3-4, 2017.

pressure transducers installed by TVA in each monitoring well were used to collect water-level data at 5-minute intervals before, during, and following the test. During the test, periodic measurements were made in the wells by Stantec using an electric tape to compare to and verify the accuracy of the continuous transducer data. Following completion of the test, the transducer data were compensated for barometric pressure using data collected from a TVA-maintained barometer located at the ALF Plant, and the data were provided to the USGS and CAESER by Stantec for use in the aquifer-test analysis.

Water-level data were collected by the USGS, CAESER, and Stantec during the test. The periodic water-level data collected by the USGS and CAESER for the Memphis aquifer from the ACC Plant production wells and the offsite observation wells are stored in the USGS NWIS (U.S.

Geological Survey, 2018). The continuous water-level data collected using transducers from the offsite Memphis aquifer observation wells were processed by and are available from the CAESER. TVA collects, stores, and maintains the waterlevel data collected from the network of MRVA aquifer monitoring wells at the ALF and ACC Plants as part of the RI. Water-level data collected from these monitoring wells that were furnished to the USGS by Stantec for use in this study are the property of the TVA and will be made available with results of the RI. 


\section{Data Analysis}

Water-level data collected during the test were evaluated using different methods. Drawdown values for the five Memphis aquifer production wells were calculated by comparing pre-test (static) and late-pumping period water levels. Recovery-period data were used to verify that water levels in the production wells returned to near-static conditions once pumping stopped. Water-level data collected from the Memphis aquifer observation wells and the MRVA aquifer monitoring wells were evaluated by comparing pre- and latepumping period continuous transducer-recorded data and by modeling the transducer data using the program SeriesSEE (Version 1.20), which is a Microsoft Excel add-in (Halford and others, 2012), to remove "environmental fluctuations" or the effects of natural and anthropogenic water-level changes in wells. Monitoring wells screened in the intermediate and deep parts of the MRVA aquifer primarily were used to evaluate results of the aquifer test; water-level data from some shallow MRVA aquifer monitoring wells that are co-located with intermediate and deep wells were not used because the water levels in the shallow wells appear to represent a perched water table or zones of limited hydraulic connectivity to the deeper parts of the aquifer. Stage data from the U.S. Army Corps of Engineers streamgage (USGS 07032000, Mississippi River at Memphis, TN) operated by the USGS on the Mississippi River about 5.5 mi upstream of the ALF Plant also were used as a baseline and surrogate for estimating water-level trends in the MRVA aquifer for separation of environmental effects during analysis of the aquifer-test data using the SeriesSEE program because of general correlation of the stage data with the MRVA aquifer water-level data locally. Input data for the model and model results for the transducer data are available from Carmichael and Kingsbury (2018).

\section{Results}

The data collected for this investigation were used to provide a preliminary evaluation of the potential for leakage from the MRVA aquifer to the Memphis aquifer in the TVA plants area. Descriptions of findings from the three main components of the evaluation provide various lines of evidence that support the conclusions of the study.

\section{Subsurface Hydrogeologic Interpretations}

Stratigraphic and lithologic data collected in the field as part of drilling of monitoring wells and stratigraphic test holes for the RI were used to develop a framework for the hydrogeologic units from land surface to the upper part of the Memphis aquifer at the TVA plants site. Lithologic descriptions of the geologic units encountered and interpretations of the depositional environments and hydrologic characteristics of the sediments composing each unit are discussed below.

\section{Anthropogenic Fill}

The upper intervals in each of the monitoring-well borings and test holes contain non-native materials, such as coal, asphalt, and angular limestone gravel, and include clumped soil. These intervals are interpreted to consist of anthropogenic-fill material mixed with tilled soil and floodplain sediment. The fill materials extend from the surface to as much as $11 \mathrm{ft}$ below land surface and commonly are layered in 0.5 - to 2 -ft-thick beds. The fill materials in stratigraphic test holes P-4c and 205c commonly have gypsum crusts and pore lining, especially where limestone gravel is present.

\section{Mississippi River Valley Alluvium}

Below the fill material, the uppermost stratigraphic unit present in the TVA plants area is the Mississippi River Valley alluvium. Thickness of the alluvium beneath the TVA plants site ranges from about 100 to $200 \mathrm{ft}$. Excluding the mainly fine-grained upper part of the alluvium, sand and gravel deposits that make up the MRVA aquifer range from about 85 to $180 \mathrm{ft}$ in the area. The subsurface deposits that make up the Mississippi River Valley alluvium beneath the TVA plants site are described in terms of five units, in descending order: upper alluvium, blue clay interval, and channel units III, II, and I. The channel units are designated based on intervals with gravel and sand at the base that fine upward to medium- to fine-grained sand.

\section{Upper Alluvium}

The upper alluvium is fine-grained tan to gray sand and olive-gray to dark-gray silty clay in beds approximately 0.5 to $5 \mathrm{ft}$ thick. The total thickness varies from 13 to $26 \mathrm{ft}$ across the TVA plants site. The sand beds are horizontal to crossbedded or ripple cross-laminated. Silt and clay intervals are commonly laminated or finely bedded. Fining upward sand to silty clay beds commonly have blocky soil structure and extensive root traces or preserved roots. The upper parts of the rooted intervals commonly are oxidized. Dark-brown to black organic matter is common in the rooted and soil structured intervals. Silt and clay intervals commonly have slight to moderate effervescence to dilute hydrochloric acid, indicating the presence of minor calcium carbonate.

Interpretation: The upper alluvium represents overbank deposits on the flood plain of the Mississippi River. The fining upward beds represent proximal deposits of individual flooding periods followed by drying and oxidation.

Similar deposits are observed in flood-plain deposits near Loosahatchie Bar across from downtown Memphis (Koontz and others, 2014; Koban, 2017). Silty clay intervals as much as $5 \mathrm{ft}$ thick represent more distal overbank deposits in back swamp settings. The lithologic characteristics of the upper alluvium at the TVA plants site is consistent with the Mississippi River Valley confining unit described by Ackerman (1996). Although the upper alluvium deposits are 
generally fine grained, they are unlikely to provide complete confinement because of extensive macroporosity resulting from soil-forming processes (rooting and drying). The upper alluvium likely acts as a leaky confining unit over the underlying MRVA aquifer.

\section{Blue Clay Interval}

The blue clay interval is composed of blue-gray silty clay and interbedded very fine-grained sand. The thickness of this interval ranges from less than $1 \mathrm{ft}$ in the boring for monitoring well MW 3A and in stratigraphic test hole P-4c to $27 \mathrm{ft}$ in test hole 212c. The designation of the blue clay interval is based on the presence of laminated to massive blue-gray silty clay that contains calcium carbonate and, in most cases, weathered millimeter-sized calcium carbonate gastropod shells. Finingupward beds that are 1 to $4 \mathrm{ft}$ thick and composed of very fine-grained sand to silt are interbedded with the clay. Fine root traces and preserved root material are common, but evidence for drying and oxidation is rare. Organic matter and less common lignite are present in the thicker intervals, such as that in stratigraphic test hole 212c. The blue clay is not definitively identified in the boring for well MW 5A, but a similar clay interval is present at the appropriate depth. A root from the upper part of the blue clay interval at $21 \mathrm{ft}$ in stratigraphic test hole $212 \mathrm{c}$ yielded a ${ }^{14} \mathrm{C}$ age of about 150 radiocarbon years before present (RCYBP; table 1). A small twig collected from the base of the blue clay interval at $35 \mathrm{ft}$ below land surface in stratigraphic test hole 205c yielded a discordant ${ }^{14} \mathrm{C}$ age of about 3,860 RCYBP.

Table 1. Radiocarbon ages for wood samples collected from the Mississippi River Valley alluvium at the Tennessee Valley Authority Allen Combined Cycle and Allen Fossil Plants.

[USGS, U.S. Geological Survey; MW, monitoring well; c, stratigraphic test hole; ${ }^{14} \mathrm{C}$, carbon-14; RCYBP, radiocarbon years before present; see figure 2 for locations of monitoring wells and figure 6 for locations of stratigraphic test holes]

\begin{tabular}{lcccrc}
\hline $\begin{array}{c}\text { Stratigraphic } \\
\text { test hole/ } \\
\text { monitoring } \\
\text { well field ID }\end{array}$ & $\begin{array}{c}\text { USGS } \\
\text { well } \\
\text { number }\end{array}$ & $\begin{array}{c}\text { Sample } \\
\text { depth (feet } \\
\text { below } \\
\text { land } \\
\text { surface) }\end{array}$ & $\begin{array}{c}\text { Fraction } \\
\text { modern } \\
\mathbf{1 4}^{4} \mathbf{C}\end{array}$ & $\begin{array}{c}{ }^{14} \mathbf{C} \text { age } \\
\text { (RCYBP) }\end{array}$ & $\begin{array}{c}\text { Precision } \\
\text { of }{ }^{14} \text { C age } \\
\text { (RCYBP) }\end{array}$ \\
\hline 205c & Sh:H-043 & 35 & 0.6186 & 3,858 & 21 \\
212c & Sh:H-041 & 21 & 0.9817 & 149 & 19 \\
212c & Sh:H-041 & 116 & 0.6868 & 3,018 & 22 \\
214c & Sh:H-042 & 112 & 0.6242 & 3,786 & 22 \\
MW 1A & Sh:H-035 & 36 & 0.6271 & 3,748 & 20 \\
MW 1A & Sh:H-035 & 56 & 0.7386 & 2,433 & 19 \\
MW 1A & Sh:H-035 & 116 & 0.3331 & 8,830 & 25 \\
MW 1A & Sh:H-035 & 166 & 0.1437 & 15,586 & 56 \\
MW 5B & Sh:H-037 & 46 & 0.8509 & 1,297 & 18 \\
\hline
\end{tabular}

${ }^{1}$ Fraction modern carbon is relative to atmospheric carbon in $1950 .{ }^{14} \mathrm{C}$ age is the uncalibrated carbon-14, in years before 1950 . The precision is \pm 1 -sigma standard deviation of multiple sample analyses.
Interpretation: The blue clay interval represents a shallow lake environment, possibly an oxbow cut-off lake. The thickest sections of the blue clay intervals (stratigraphic test holes 212c and 214c) are present where the upper alluvium is the thinnest (13 and $14 \mathrm{ft}$ thick, respectively). This suggests that the lake co-existed in time with neighboring fluvial overbank areas. The species of gastropod shells was not identifiable, but visual assessment indicates that they are similar to pond species identified in Pleistocene lake deposits near Fulton, Tennessee (Grimley and others, 2009). The lower contact of the blue clay interval is commonly abrupt, with clay deposits overlying gravelly sand with or without root traces. This observation suggests a sudden change in the depositional environment, such as abrupt channel cutoff and isolation of the soon-to-be lake from the coarse-grained channel sediment. The approximately 150-year age of the root from the upper part of the blue clay interval suggests that the inferred oxbow lake may have existed until recent times. The discordant age of the twig in stratigraphic test hole 205c likely represents reworking of old wood.

The blue clay interval is likely to impede vertical movement of water locally. The degree of rooting is not extensive, nor is the interval particularly broken or disrupted. The interval is likely to cause local perching of water in the overlying upper alluvium and possibly confinement of water in the underlying MRVA aquifer during high water-level conditions where the blue clay interval is thickest. Thinner intervals of blue clay, such as at the location of monitoring well MW 3A, are more rooted and may be locally removed by erosion, allowing for hydraulic connection between the overlying and underlying alluvium intervals.

\section{Channel Unit III}

Channel unit III is the uppermost recognizable finingupward gravel to sand interval observed in stratigraphic test holes and monitoring-well borings at the TVA plants site. The interval is identified in stratigraphic test holes $212 \mathrm{c}$ and 205c, but may also be present in the boring for monitoring well MW 216 and the upper gravel-bearing intervals of the borings for wells MW 1A and MW 5A. The most complete preservation is in stratigraphic test hole 212c, where a basal gray gravel and sand interval at 93 to $76 \mathrm{ft}$ below land surface abruptly fines upward to very fine-grained laminated and cross-laminated gray to olive-gray sand and silt that persists from 76 to $44 \mathrm{ft}$ below land surface. Calcium carbonate and sparse fine gastropod fragments are present in the upper part of the silt interval. Fining-upward gravel to sand intervals with minor interbedded silt are observed in stratigraphic test hole 205c and in the borings for monitoring wells MW 1A and MW 5A. A partially oxidized gravel and gravelly sand interval is observed from 57 to $26 \mathrm{ft}$ below land surface in stratigraphic test hole P-4c and may be the youngest part of the channel unit III complex or a separate young channel. The gravel is composed mainly of tan to white chert and white quartzite. The gravel and sand are notably rich in lignite 
chips. Small branches to chips of wood are present in many intervals. The larger pieces of wood have ${ }^{14} \mathrm{C}$ ages that range from about 2,430 RCYBP in basal gravels in the boring for monitoring well MW 1A to 1,300 RCYBP in upper sand-rich beds in the boring for MW 5B (table 1). A discordant age of about 3,750 RCYBP was obtained for fine woody material at the top of the unit in the boring for monitoring well MW 1A; however, this likely is reworked older wood.

Interpretation: Channel unit III represents channel deposits of the Mississippi River. The overall fining-upward grain-size trend and thickness in stratigraphic test hole 212c are consistent with the channel of a large meandering stream. Cross-laminated very fine-grained sandy silt is present in the unit and likely represents point-bar deposits over the channel gravel. However, the uppermost calcium carbonate- and gastropod-bearing silt represents a transition to the overlying blue clay interval. An interval of greenish- to olive-gray horizontal and cross-bedded very fine- to medium-grained sand in the boring for monitoring well MW 216 likely represents a nonvegetated channel bar similar to those that exist in the Mississippi River near Memphis (Koban, 2017). The position of point-bar deposits in stratigraphic test hole 212c and the channel bar in the boring for monitoring well MW 216 suggest that the channel migrated west with time. Thus, if the gravel-rich interval from 57 to $26 \mathrm{ft}$ below land surface in stratigraphic test hole P-4c is related to channel unit III, it represents the youngest part of this channel system.

The gravel-rich intervals of channel unit III represent a hydraulically conductive upper zone in the MRVA aquifer at the TVA plants site. The hydrologic effect of the sand and gravel within this interval is likely to be most pronounced in the area of stratigraphic test holes P-4c and 205c.

\section{Channel Unit II}

Channel unit II is recognized in the borings for all monitoring wells and stratigraphic test holes that penetrated through the entire Mississippi River Valley alluvium. The base of the interval begins between 135 and $115 \mathrm{ft}$ below land surface. Channel unit II is composed of gray sand and gravel that fine upward to fine- to medium-grained sand. Bedding structure is rarely present, but where present, includes horizontal bedding and various types of cross bedding. The gravel is composed mainly of tan to white chert, with lesser quantities of white quartzite, dark-gray to green metasedimentary clasts, red volcanic tuff, and various granite and gneiss clasts. Lignite, gravel, and sand are common in many beds, and boulder-size blocks of Tertiary mudstone are interpreted as locally present. Wood logs and branches are preserved in several beds. A log at the base of channel unit II at $116 \mathrm{ft}$ below land surface in the boring for monitoring well MW 1A has a ${ }^{14} \mathrm{C}$ age of about 8,800 RCYBP (table 1 ). However, wood logs near the base of channel unit II in stratigraphic test holes 212c and 214c have ages of about 3,020 at $116 \mathrm{ft}$ below land surface and 3,790 RCYBP at $112 \mathrm{ft}$ below land surface, respectively.
Interpretation: Channel unit II represents channel deposits of the modern Mississippi River and is a hydraulically conductive intermediate zone of the MRVA aquifer at the TVA plants site. The most complete fining-upward sequences are from the boring for monitoring well MW 3A at the western side of the ACC Plant and from stratigraphic test hole 214c, the southwestern-most of the four test holes drilled at the ALF Plant. The gravel clast composition notably contains red volcanic tuff, which is likely to have originated from the St. Francis Mountains in Missouri and indicates Mississippi River sediment sources (Ward and others, 2017). The age of the wood log from the base of the unit also corresponds well to similar sediments and radiocarbon results from modern Mississippi River deposits near Marion, Arkansas (Ward and others, 2017); however, the wood logs from above the base of the channel unit suggest a late Holocene age for much of the channel fill.

\section{Channel Unit I}

Channel unit I is identified in the borings for monitoring wells MW 1A and MW 5A and in stratigraphic test hole 212c. The base of the unit ranges from $228 \mathrm{ft}$ below land surface in stratigraphic test hole 212c to $140 \mathrm{ft}$ below land surface in the boring for well MW 5A. Channel unit I is composed of gray sand and gravel that fines upward to fine- to medium-grained sand with sparse pebbles. The gravel is composed mainly of tan to white chert, with lesser quantities of white quartzite, gray metasedimentary clasts, red volcanic tuff, and granite clasts. Lignite and lignitic mudstone, gravel, and sand are common in the boring for monitoring well MW 1A, but not in the other monitoring-well borings. Small branches of wood are rare. A branch at the base of channel unit I at $166 \mathrm{ft}$ below land surface in the boring for monitoring well MW 1A has an age of about 15,600 RCYBP (table 1).

Interpretation: Channel unit I represents the deepest channel deposits of the Mississippi River and is the lowermost hydraulically conductive zone of the Mississippi River Valley alluvium at the TVA plants site. Overall downward incision into underlying Eocene strata and thickening of the channel deposits toward the eastern margin of the site suggest that channel scour occurred adjacent to the Mississippi River bluffs. The radiocarbon age obtained from the base of the Mississippi River Valley alluvium in the boring for monitoring well MW 1A is consistent with the Kennett or Blodgett alluvium of the Pleistocene Mississippi River (Rittenour and others, 2007; Ward and others, 2017). The gravel clast composition is generally similar to that of channel unit II, suggesting similar origins and deposition from integration of the Mississippi and Ohio Rivers that occurred beginning about 18,000 years ago (Blum and others, 2000).

\section{Cook Mountain Formation}

The Cook Mountain Formation underlies the Mississippi River Valley alluvium at the TVA plants site. The contact is 
disconformable and has as much as $110 \mathrm{ft}$ of erosional relief. The preserved Cook Mountain Formation ranges from 26 to about $75 \mathrm{ft}$ thick at the TVA plants site. The Cook Mountain Formation is composed primarily of very fine-grained sandy to silty mudstone with interlaminated silty very fine-grained sand. The color is generally olive-gray to gray, but is locally light gray directly beneath the contact with the Mississippi River Valley alluvium. The mudstone is generally laminated to finely cross-laminated. Inclined beds with more very finegrained sand than mudstone are present in the lower $12 \mathrm{ft}$ of the Cook Mountain Formation in stratigraphic test hole P-4c. The sand is commonly micaceous, but is mainly composed of quartz. Chips of lignitic plant debris and leaves are common along partings and in sandy beds. The mudstone locally has fractures at 30 degrees to bedding with slickensides. The fractures are most prominent in stratigraphic test hole 212c, but are present in minor amounts in test hole P-4c. Sand-filled vein-fractures are present in stratigraphic test hole 212c.

Interpretation: The Cook Mountain Formation at the TVA plants site represents ancient delta-front and prodelta deposits. The inclined sandy beds at the base of the unit in stratigraphic test hole P-4c are similar to those observed in outcrop of the Cook Mountain Formation along the Mississippi River near Fulton, Tennessee, where the beds represent delta-front deposits into an ancient coastal lake (Tye and Coleman, 1989). The ripple cross-lamination commonly shows aggradation and downgradient migration, typical of deposits from decelerating turbid flows. The pervasive lamination observed is common for distal deposits of turbid flows from a delta into shallow water. The abundance of lignitic material is interpreted to derive from densely vegetated ancient coastal swamps and forests that bordered the deltaic distributary channels.

The sand-filled veins are interpreted to reflect local sanddike formations, perhaps from ancient earthquakes or dilation resulting from incipient delta slope failure. Paleoliquefaction features have been observed in upper Claiborne Group strata in northwestern Shelby County (Ferreira and others, 2013). The fractures are probably the result of more recent phenomena, mainly because of their fresh appearance and preservation of slickensides. The prominence of fractures in the unit in stratigraphic test hole $212 \mathrm{c}$ may reflect slumping processes along the bluff or disruption from nearby faults.

The Cook Mountain Formation is the primary and most clay-rich component of the upper Claiborne confining unit for the Memphis aquifer in the Memphis area (Parks, 1990). At the TVA plants site, the Cook Mountain Formation is composed primarily of clay and is a low-permeability unit that restricts movement of water between the MRVA and Memphis aquifers.

\section{Transition of Cook Mountain Formation to Memphis Sand}

Based on observations from the four stratigraphic test holes drilled at the ALF Plant, the contact of the Memphis
Sand with the overlying Cook Mountain Formation is conformable and gradational. Seven to $25 \mathrm{ft}$ of interbedded white very fine-grained sand and light-gray sandy silt are present between the sand-dominated Memphis Sand and mud-dominated Cook Mountain Formation and represent a transitional interval. Applying stratigraphic standards for the Cook Mountain Formation from Parks (1990) and Kingsbury and Parks (1993), the transitional interval with roughly equal content of sand and mud is ascribed to the Cook Mountain Formation so as to maintain similar formation thickness across the area. The transitional interval is composed of interbedded white to light-gray very fine-grained sand and laminated silty mud. Intraclasts of mud are common in the sand, and some mud intervals are broken. Lignite flakes are common in the silty mud. The sand is mostly quartz with a trace of silt or clay. Grain size increases and sorting improves with depth in the interval.

\section{Memphis Sand}

The four stratigraphic test holes drilled at the ALF Plant penetrated at least $13 \mathrm{ft}$ of the upper Memphis Sand. Samples of the Memphis Sand from the borings consist of white very fine- to fine-grained sand with a few mud beds that are up to $0.5 \mathrm{ft}$ thick. The sand is well sorted and is composed of quartz and dispersed lignite flakes.

Interpretation: The transitional interval of the Cook Mountain Formation to the Memphis Sand and the upper part of the Memphis Sand penetrated in the four test holes at the ALF Plant are interpreted as mouth bar and deltaic distributary channel deposits. The interbedded mud and sand likely reflect sedimentation of turbid waters at the terminus of the distributary channel, where flow becomes unconfined (for example, a delta mouth bar). The prominence of intraclasts in the sand is the result of caving of fine-grained flood-plain deposits, similar to channel deposits observed elsewhere in the Memphis Sand (Gentry and others, 2006; Larsen and Brock, 2014). The moderate sorting of the sands and inclusion of fine lignitic material are consistent with hydrodynamic processes in river and distributary channels.

The transitional interval between the mud of the Cook Mountain Formation and the well-sorted sands of the Memphis Sand are likely to impede vertical groundwater flow, but less so than the mud of the Cook Mountain Formation. The well-sorted sand is part of the Memphis aquifer; however, the most productive groundwater zones are deeper in the Memphis Sand.

\section{Geologic Structure}

Correlation of stratigraphic units at the TVA plants site and comparison with geophysical logs from nearby wells were used to produce cross sections spanning the study area (figs. 6-9). These correlations suggest that stratigraphic units are offset along faults, one cutting southwest to northeast 
across the TVA site between the ALF and ACC Plants, and another following the Mississippi River bluff line east of the TVA plants site (fig. 6). The upper contact of the Cook Mountain Formation with the Mississippi River Valley alluvium is disconformable, and the variation in the depth of the contact reflects variable depth of erosion by the Mississippi River during late Pleistocene and Holocene time. The lower contact of the Cook Mountain Formation is considered the base of the transitional interval to the underlying Memphis Sand. Information is available about the depth of the upper contact of the Cook Mountain Formation from rotasonic core data from most of the borings for monitoring wells screened in the lower part of the MRVA aquifer and from the four stratigraphic test holes drilled at the ALF Plant as part of the RI. The depth of the lower contact is less certain because the top of the Memphis Sand was only penetrated in the four stratigraphic test holes and because the surface casing of the production wells drilled at the ACC Plant prevented data collection using electric geophysical-log methods and limited definition and resolution of natural gamma-ray log data. Furthermore, geologic correlations of data for offsite Memphis aquifer wells (wells Sh:H-001, Sh:H-002, and Sh:H-013; fig. 6) are based solely on geophysical logs and, as a result, lack the additional resolution available from core data. Interpretation of faulting throughout the Memphis area based on apparent offsets of the Cook Mountain Formation and top of the Memphis Sand is difficult because of the gradational transition across these units. Deep stratigraphic information (for example, the base of the Memphis aquifer) used in concert with shallow data allows for greater confidence in interpretation of the stratigraphy and the apparent offsets.

The inferred fault with a trace passing from southwest to northeast between the TVA ACC and ALF Plants is interpreted to have up-to-the-north offset (figs. 6-8). The lower contact of the Cook Mountain Formation has a shallow northerly dip north of the ACC Plant in cross-sections $A-\mathrm{A}^{\prime}$ and $\mathrm{B}-\mathrm{B}^{\prime}$ (figs. 7 and 8); however, the lower contact of the Cook Mountain Formation in cross-section C-C' (fig. 9) is nearly horizontal within the Mississippi River Valley at the TVA plants site. Between production well PW 5 and stratigraphic test hole 214c, and between stratigraphic test holes 212c and 205c (figs. 7 and 8), the Cook Mountain Formation is interpreted to have upward offset on the northern side of the inferred fault trace. Additionally, marker beds in the Mississippi River Valley alluvium (blue clay interval) may be offset along this inferred fault across the TVA plants area. The inferred fault follows the southwest-to-northeast trend of several identified faults in the area, including the MeemanShelby Fault (Hao and others, 2013; Ward and others, 2017) and the Big Creek Fault (Van Arsdale and Cupples, 2013).

Another offset of the stratigraphic units is interpreted along the eastern border of the TVA plants site based on a natural gamma-ray log made in the test hole for observation well Sh:H-001 at T.O. Fuller State Park (fig. 9). The stratigraphic units overlying the Cook Mountain Formation at this well location are the Pliocene-Pleistocene-age fluvial (terrace) deposits and Pleistocene-age loess, both of which are verified by surface exposures in the area. Based on interpretation made for this study, as much as $130 \mathrm{ft}$ of offset may be present on the lower contact of the Cook Mountain Formation at this well location, with the relative motion up to the east along the fault. Martin and Van Arsdale (2017) identified a fault in this area based on a regional study of offset of the lower contact of the Cook Mountain Formation. Previous interpretations of the natural gamma-ray log of observation well Sh:H-001 in the context of the hydrogeology of the Memphis area (Parks, 1990; Kingsbury and Parks, 1993) indicate a lower altitude base and greater thickness of the Cook Mountain Formation in this well. The alternate interpretations of the thickness and depth to the base of the Cook Mountain Formation illustrate the difficulty in conclusively characterizing the contact between the upper Claiborne confining unit and the Memphis Sand and potential offsets in these units without deep stratigraphic control.

The inferred faults have implications for groundwater movement between the MRVA and Memphis aquifers where offset may provide for hydraulic connection between the two units. However, uncertainty in the character and thickness of the Cook Mountain Formation away from the observation wells and constraint in determining the amount of offset along the inferred faults in the absence of deep geologic control preclude definitive interpretation of a hydraulic connection along the faults. 


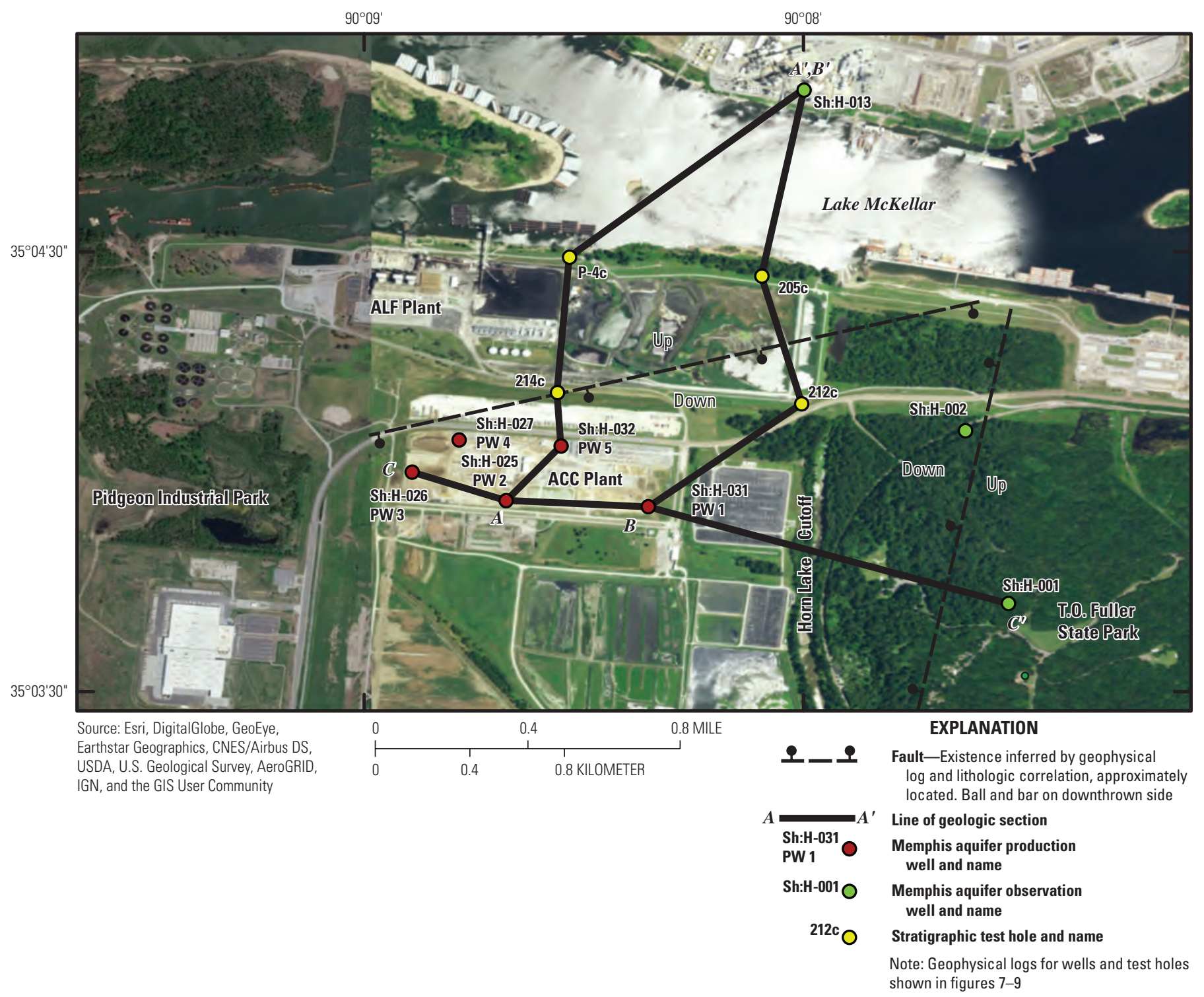

Figure 6. Locations of cross sections and inferred faults, Tennessee Valley Authority Allen Combined Cycle and Allen Fossil Plants area. 
告

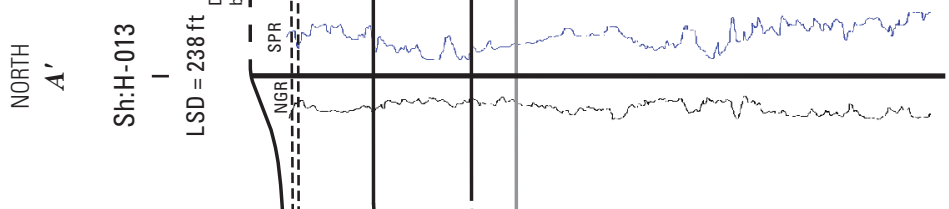
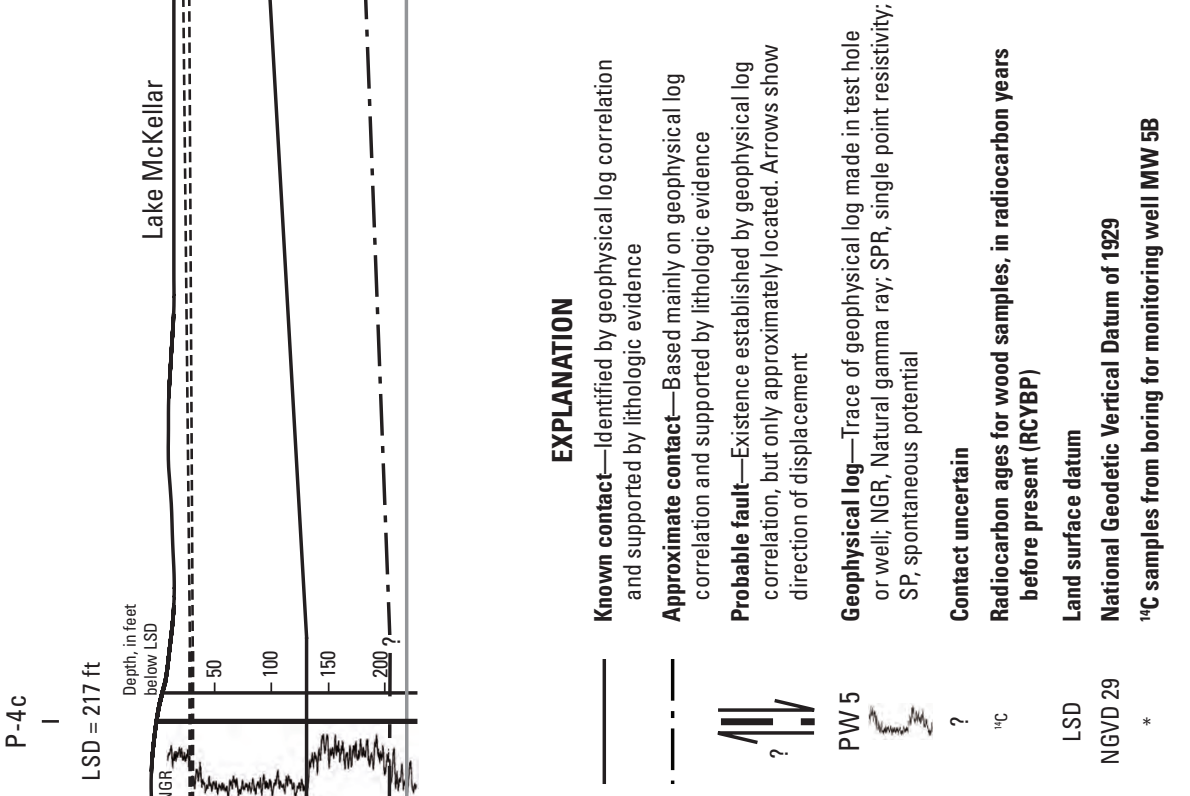

年
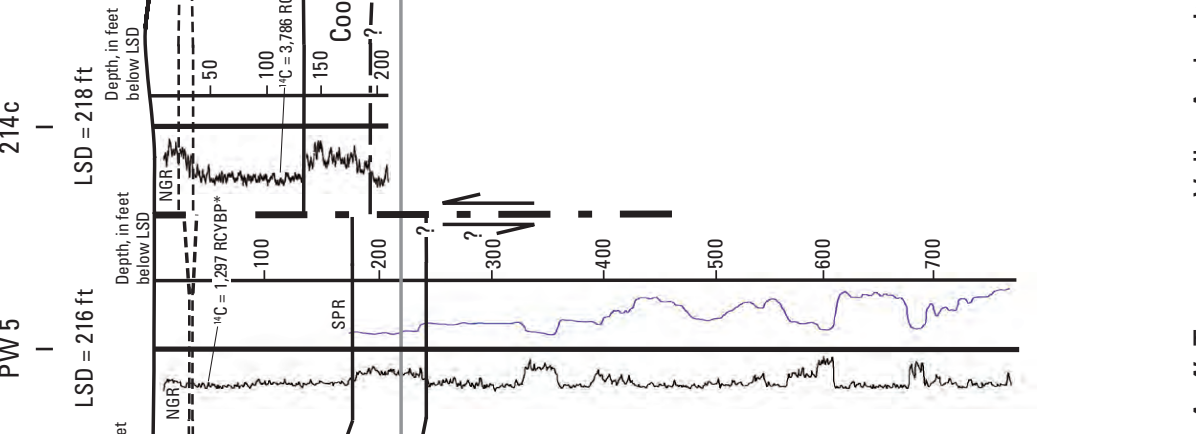


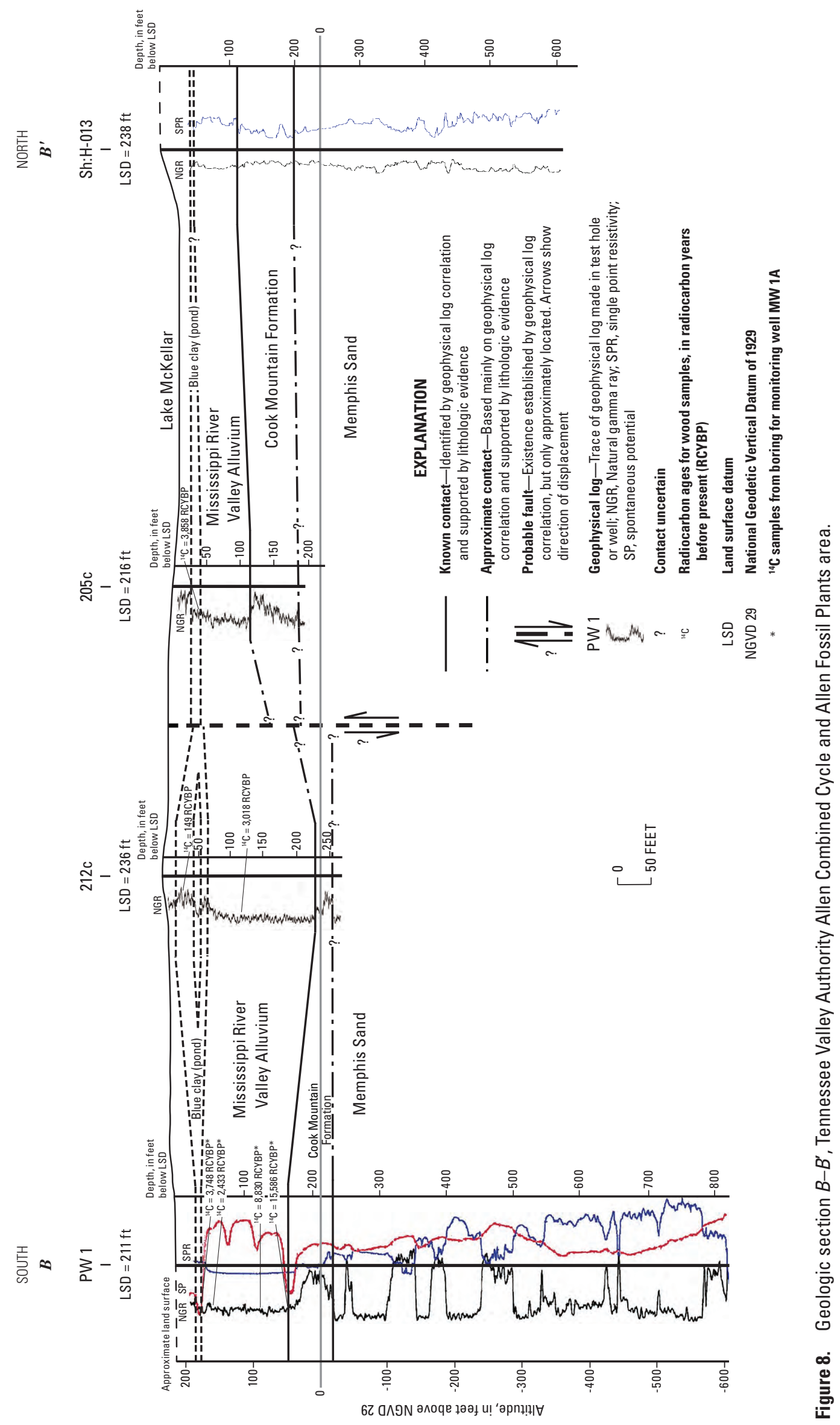




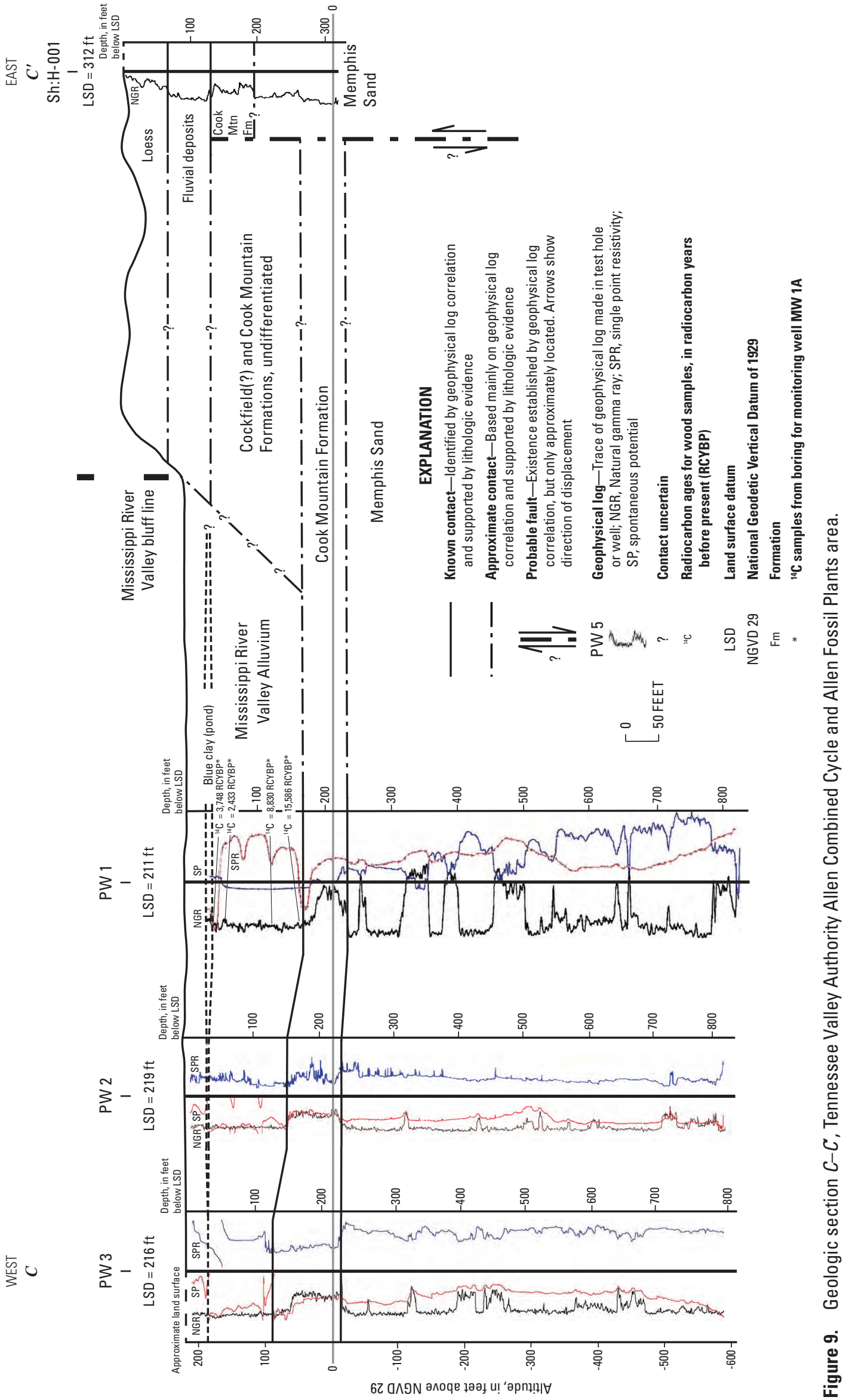




\section{Water Quality}

SC and total dissolved solids (TDS) data for samples collected in September 2017 (table 2) and SC data for samples collected in October 2017 (table 3) indicate a substantial difference in water quality between the wells screened in the MRVA aquifer and wells screened in the Memphis aquifer, with the MRVA aquifer having higher SC and TDS than the Memphis aquifer. Values of SC and TDS for samples collected from the MRVA aquifer monitoring wells at the ACC Plant in September 2017 ranged from 550 to about 890 microsiemens per centimeter at 25 degrees Celsius $\left(\mu \mathrm{S} / \mathrm{cm}\right.$ at $\left.25^{\circ} \mathrm{C}\right)$ and 282 to 537 milligrams per liter (mg/L), respectively (table 2). In contrast, the ranges of SC and TDS for samples collected from the Memphis aquifer production wells in September were 171 to $391 \mu \mathrm{S} / \mathrm{cm}$ at $25^{\circ} \mathrm{C}$ and 100 to $233 \mathrm{mg} / \mathrm{L}$, respectively (table 2). SC values for samples collected from the Memphis aquifer in October 2017 ranged from about 150 to $393 \mu \mathrm{S} / \mathrm{cm}$ at $25^{\circ} \mathrm{C}$ (table 3). The ranges of SC and TDS for both aquifers are comparable to those measured in groundwater samples collected from wells at and west of the MLGW Davis well field (Parks and others, 1995).

The relative proportion of major ions for the September 2017 samples, as illustrated on a Piper diagram (fig. 10), is similar for waters in both aquifers and is predominantly a calcium-magnesium-bicarbonate type. Concentrations of these major ions, however, were generally two to five times greater in samples from the MRVA aquifer than in samples from the Memphis aquifer (table 2). Cation and anion charge balances were 5 percent or less for all samples collected in September 2017, and concentrations of filtered and unfiltered constituents generally were comparable (table 2).

Samples from both aquifers indicate predominantly anoxic conditions - generally defined as DO concentrations less than about $0.5 \mathrm{mg} / \mathrm{L}$ (tables 2 and 3). As the result of these reducing conditions, nitrate was not detected in samples collected from either aquifer in September 2017 (table 2) and was detected in only one Memphis aquifer production well at a concentration equal to its reporting level in October 2017 (table 3). Also as a result of the reducing conditions, iron concentrations were about 1,000 micrograms per liter $(\mu \mathrm{g} / \mathrm{L})$ in samples from the Memphis aquifer and about 3,000 to 25,000 $\mu \mathrm{g} / \mathrm{L}$ in samples from the MRVA aquifer (table 2).

Similar to results for major ions, concentrations of trace elements that were detected in both aquifers were higher in samples from the MRVA aquifer than in those from the Memphis aquifer (table 2). Results for filtered samples are discussed herein because these results were not affected by differences in sample turbidity and, overall, the filtered and unfiltered results were comparable (table 2). None of the trace elements analyzed were detected at concentrations exceeding drinking-water criteria (U.S. Environmental Protection Agency, 2018). Arsenic was detected in samples from the five monitoring wells screened in the MRVA aquifer at the ACC Plant, with concentrations ranging from 0.51 to $5.44 \mu \mathrm{g} / \mathrm{L}$. Arsenic commonly is detected in samples across the extent of the MRVA aquifer and likely is present in the groundwater because of the sediments that make up the aquifer (Kresse and Fazio, 2003; Kingsbury and others, 2014). Arsenic concentrations in samples from the Memphis aquifer production wells $(0.08-0.14 \mu \mathrm{g} / \mathrm{L})$ were about an order of magnitude less than the concentrations in samples from the MRVA aquifer wells.

Tritium analyses were used to qualitatively evaluate groundwater age. The presence of tritium in groundwater samples indicates that groundwater in an aquifer includes a component of young water (post-1950). Tritium is a naturally occurring isotope of hydrogen, and since about 1950, atmospheric concentrations of tritium have varied over time, peaking during the late 1950s and 1960s when testing of nuclear weapons added substantial amounts of tritium to the atmosphere. Tritium has been proven to be a useful tool in the Memphis area for identifying areas of downward leakage of groundwater from the shallow aquifers to the Memphis aquifer (Graham and Parks, 1986; Larsen and others, 2016). As part of the September 2017 sampling event, groundwater samples also were collected from all of the production and monitoring wells at the ACC Plant for analysis of tritium to confirm the presence of young water in the MRVA aquifer and to determine if a component of young water is present in the Memphis aquifer. Tritium was present in the samples collected from the MRVA aquifer and ranged from 2.13 to 5.59 tritium units (TU) (table 4). Three of the Memphis aquifer production wells (PW 1, PW 2, and PW 4) did not have detectable tritium concentrations. Production well PW 3 had a low concentration (0.25 TU), and PW 5 had a tritium concentration of $1.24 \mathrm{TU}$. These data indicate a general relation between tritium occurrence and depth of the screened interval in the wells (fig. 11); production well PW 5, the well with the shallowest depth to the top of the screen, contained water with the highest tritium concentration. The presence of tritium at production wells PW 3 and PW 5 indicates that a component of young water is present in the upper part of the Memphis aquifer at the depths and locations of these wells. 


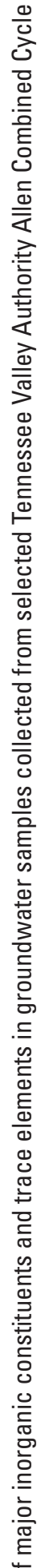

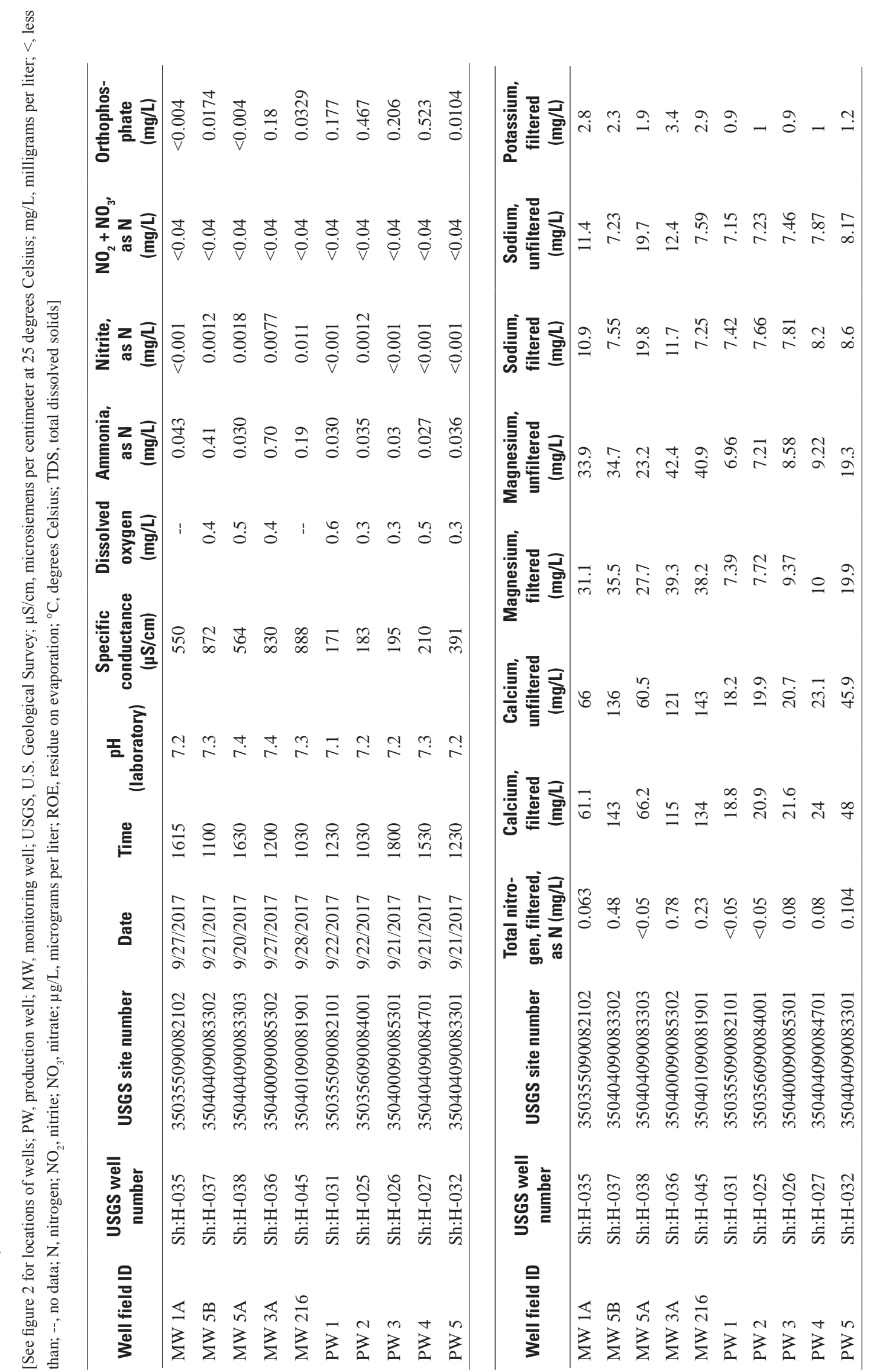




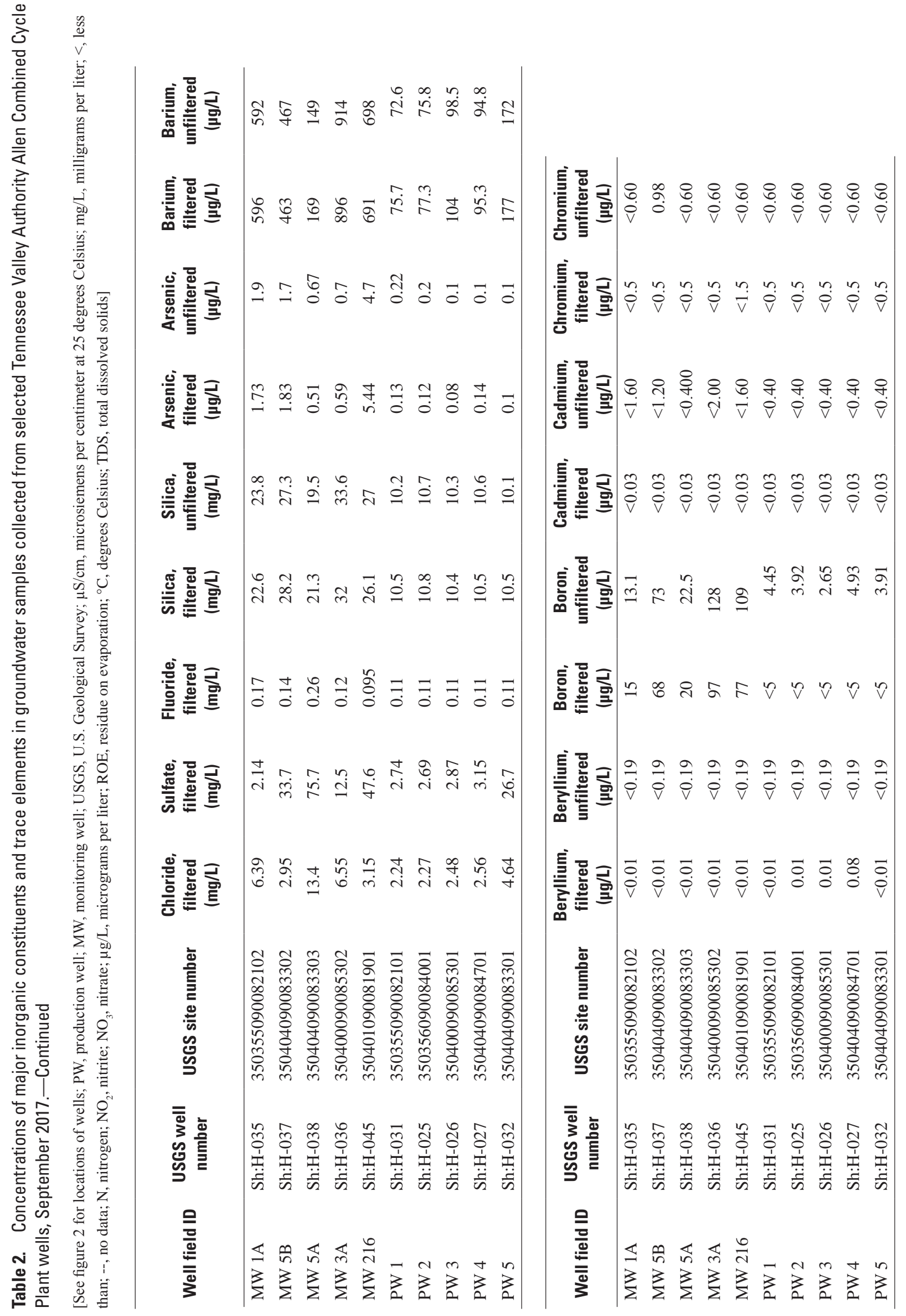




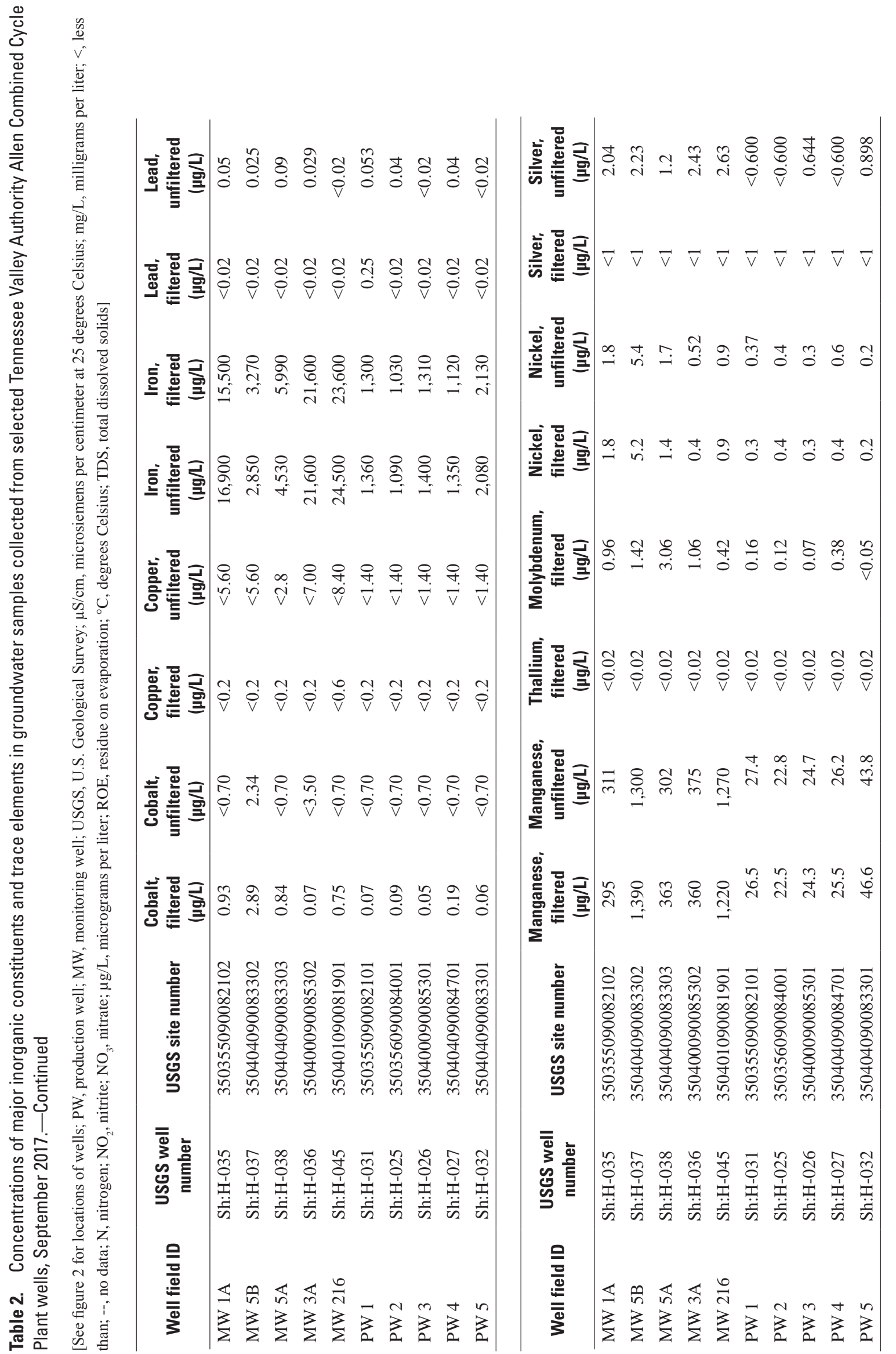



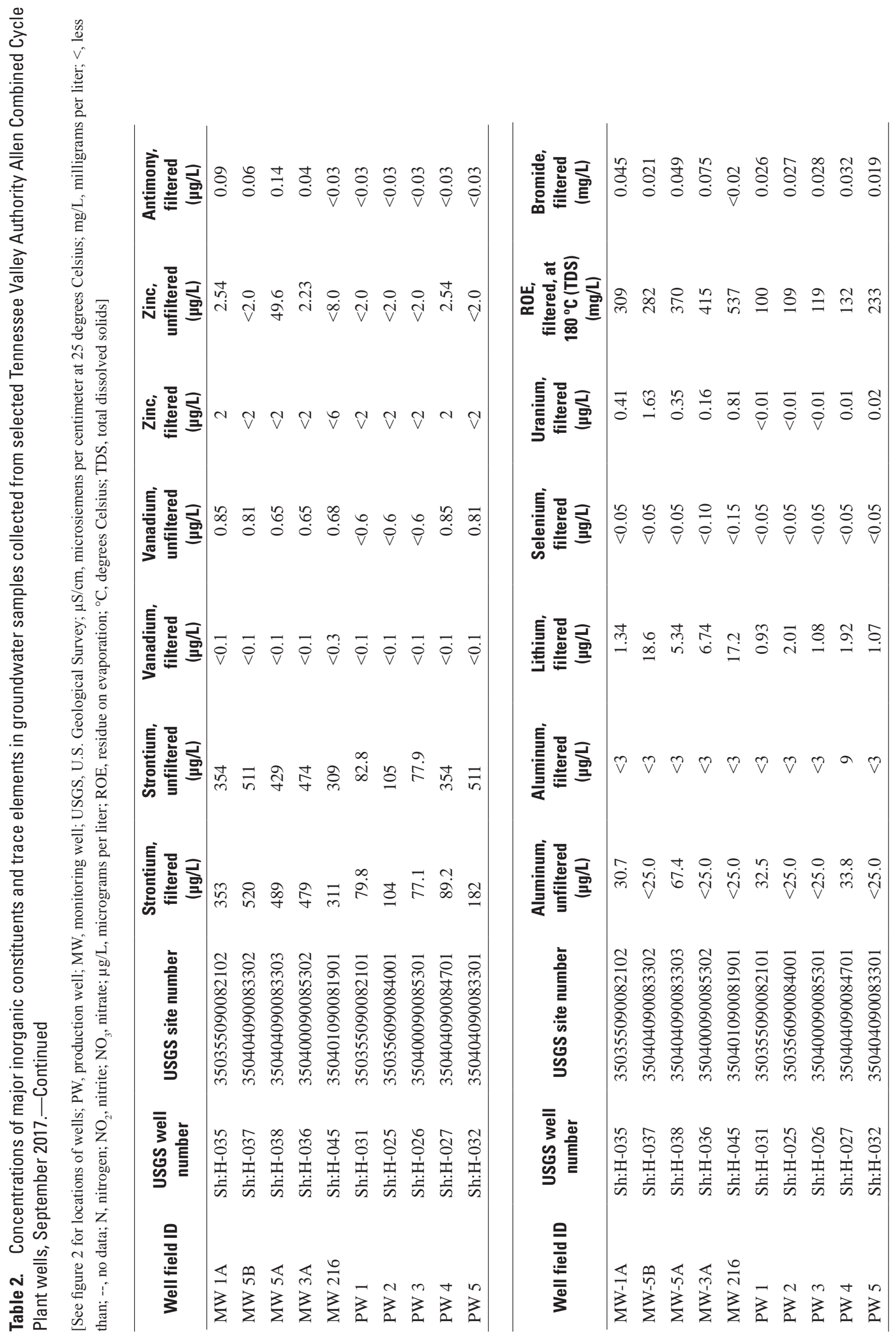


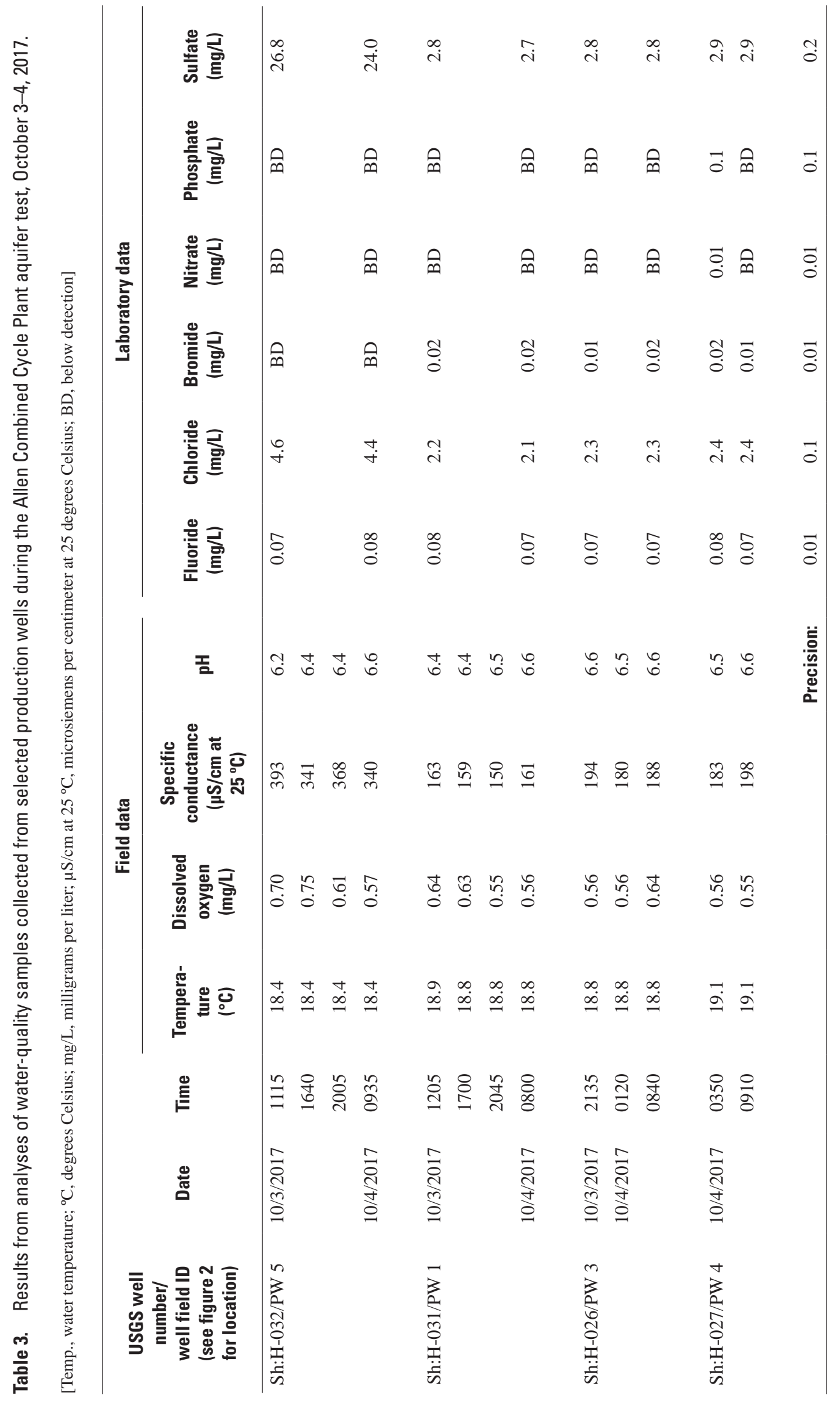




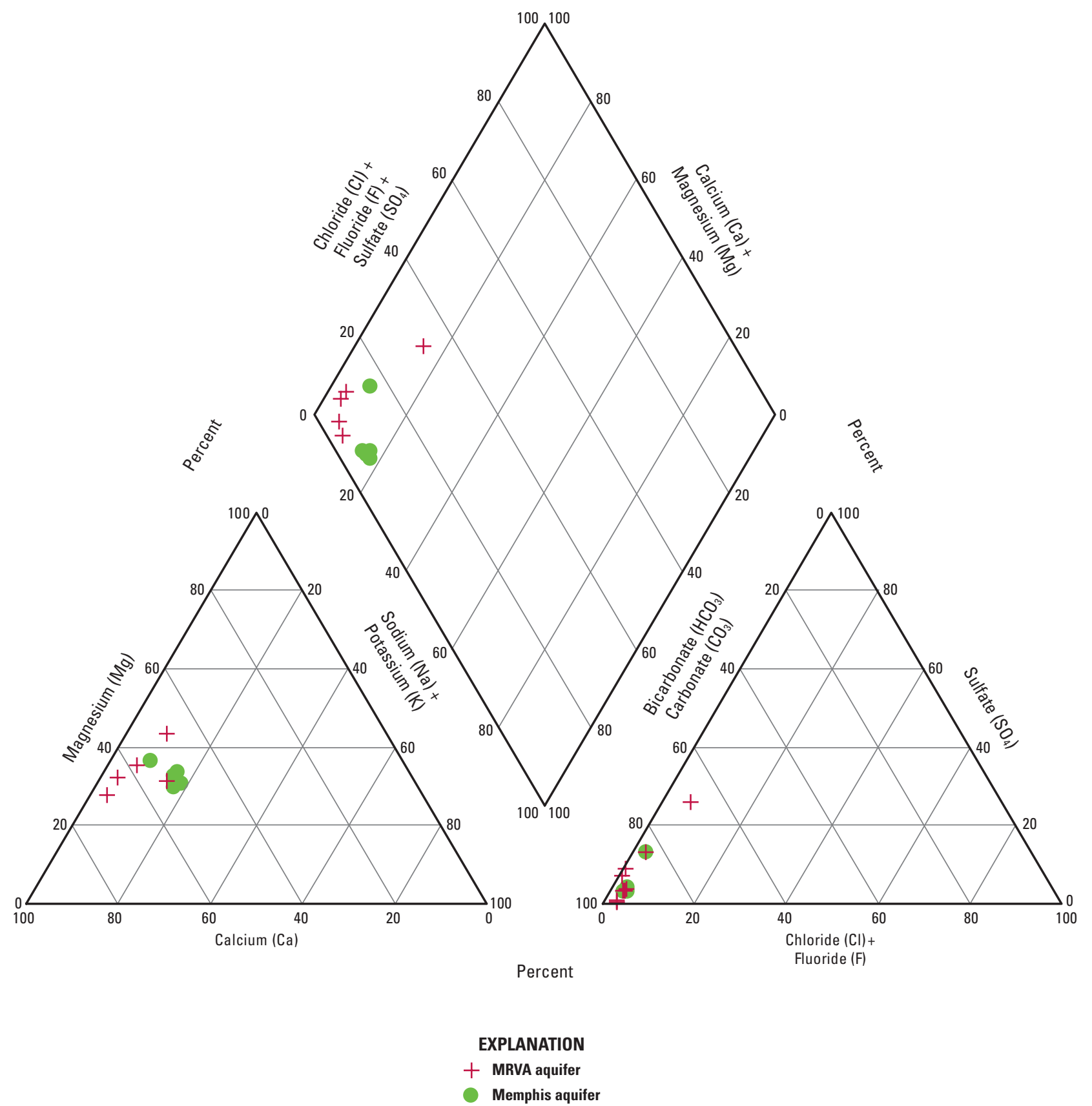

Figure 10. Chemical characteristics of groundwater samples collected from wells at the Tennessee Valley Authority Allen Combined Cycle Plant, September 2017. 
Table 4. Concentrations of tritium in groundwater samples collected from selected Allen Combined Cycle Plant wells, September and October 2017.

[Critical values (approximate detection level) for these samples ranged from 0.13 to 0.25 picocurie per liter (pCi/L); USGS, U.S. Geological Survey; TU, tritium units; --, no data; $<$, less than]

\begin{tabular}{|c|c|c|c|c|c|}
\hline \multirow{2}{*}{$\begin{array}{l}\text { Well field } \\
\text { ID (see } \\
\text { figure } 2 \text { for } \\
\text { location) }\end{array}$} & \multirow{2}{*}{$\begin{array}{l}\text { USGS } \\
\text { well } \\
\text { number }\end{array}$} & \multicolumn{2}{|c|}{ September 2017} & \multicolumn{2}{|c|}{ October 2017} \\
\hline & & $\begin{array}{l}\text { Tritium } \\
\text { (pCi/L) }\end{array}$ & $\begin{array}{l}\text { Tritium } \\
\text { (TU) }\end{array}$ & $\begin{array}{l}\text { Tritium } \\
\text { (pCi/L) }\end{array}$ & $\begin{array}{c}\text { Tritium } \\
\text { (TU) }\end{array}$ \\
\hline \multicolumn{6}{|c|}{ Mississippi River Valley alluvial aquifer } \\
\hline MW 1A & Sh:H-035 & 17.5 & 5.44 & -- & -- \\
\hline MW 5B & Sh:H-037 & 6.87 & 2.13 & -- & -- \\
\hline MW 5A & Sh:H-038 & 8.37 & 2.60 & -- & -- \\
\hline MW 3A & Sh:H-036 & 18 & 5.59 & -- & -- \\
\hline MW 216 & Sh:H-045 & 15.5 & 4.81 & -- & -- \\
\hline \multicolumn{6}{|c|}{ Memphis aquifer } \\
\hline PW 1 & Sh:H-031 & 0 & 0 & $<0.14$ & 0 \\
\hline PW 2 & Sh:H-025 & 0 & 0 & -- & -- \\
\hline PW 3 & Sh:H-026 & 0.79 & 0.25 & 0 & 0 \\
\hline PW 4 & Sh:H-027 & $<0.14$ & 0 & 0 & 0 \\
\hline PW 5 & Sh:H-032 & 4.01 & 1.24 & 3.51 & 1.09 \\
\hline
\end{tabular}

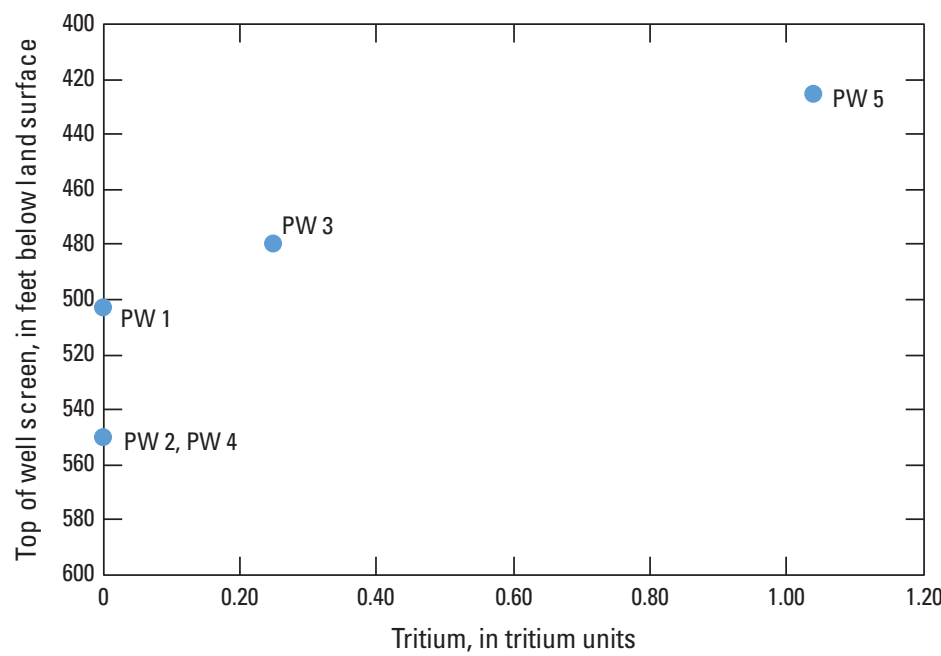

Figure 11. Tritium concentrations in groundwater samples in relation to the depths of the tops of the screens for Memphis aquifer production wells at the Tennessee Valley Authority Allen Combined Cycle Plant, September 2017.
The elevated SC and the corresponding elevated concentrations of major inorganic constituents in the sample collected from production well PW 5 in September 2017 reflect a mixture of high SC and TDS from water in the MRVA aquifer and lower SC and TDS from water in the Memphis aquifer. The SC and low tritium concentration at production well PW 3 also indicate a component of young water, but the proportion of young to old water is substantially smaller than that at well PW 5. Water-quality samples collected from the four pumping production wells during the aquifer test in October 2017 (table 3) are similar to the set of water-quality samples collected in September 2017. The most notable difference is the absence of tritium in the sample collected from production well PW 3 in October 2017 (table 4), suggesting that little if any young water was present in the Memphis aquifer at this location when the sample was collected. Water-quality samples collected by the Layne Christensen Company during performance testing of the production wells in 2016 and by TVA in June-July 2017 (TVA, written commun., 2017) showed elevated concentrations of inorganic constituents in production well PW 5, indicating that mixing of MRVA aquifer water with water in the upper part of the Memphis aquifer may predate production well installation.

Although the water-quality data indicate that young water with higher TDS concentrations is moving from the MRVA aquifer into the Memphis aquifer in the area near the ACC Plant, they also indicate that the source of the young water may differ from that in the MRVA aquifer directly beneath the ACC Plant. The water quality in the Memphis aquifer at production well PW 5 is interpreted to reflect a binary mixture of Memphis aquifer and MRVA aquifer waters and, as such, should lie along a mixing line between points that represent end-member concentrations for the two aquifers (for example, production wells PW 1 and PW 2 and MRVA aquifer samples). Samples from two of the five MRVA monitoring wells fall near a hypothetical mixing line for magnesium and calcium for the Memphis aquifer samples, but the other three samples do not (fig. 12A). None of the MRVA monitoring well samples fall on the mixing line for calcium and boron (fig. 12B), suggesting that the source of the water that represents the MRVA aquifer end member differs from that in the MRVA aquifer beneath the ACC Plant, and that the component of MRVA aquifer water present in the samples collected from the Memphis aquifer production wells originated from locations away from the ACC Plant. 

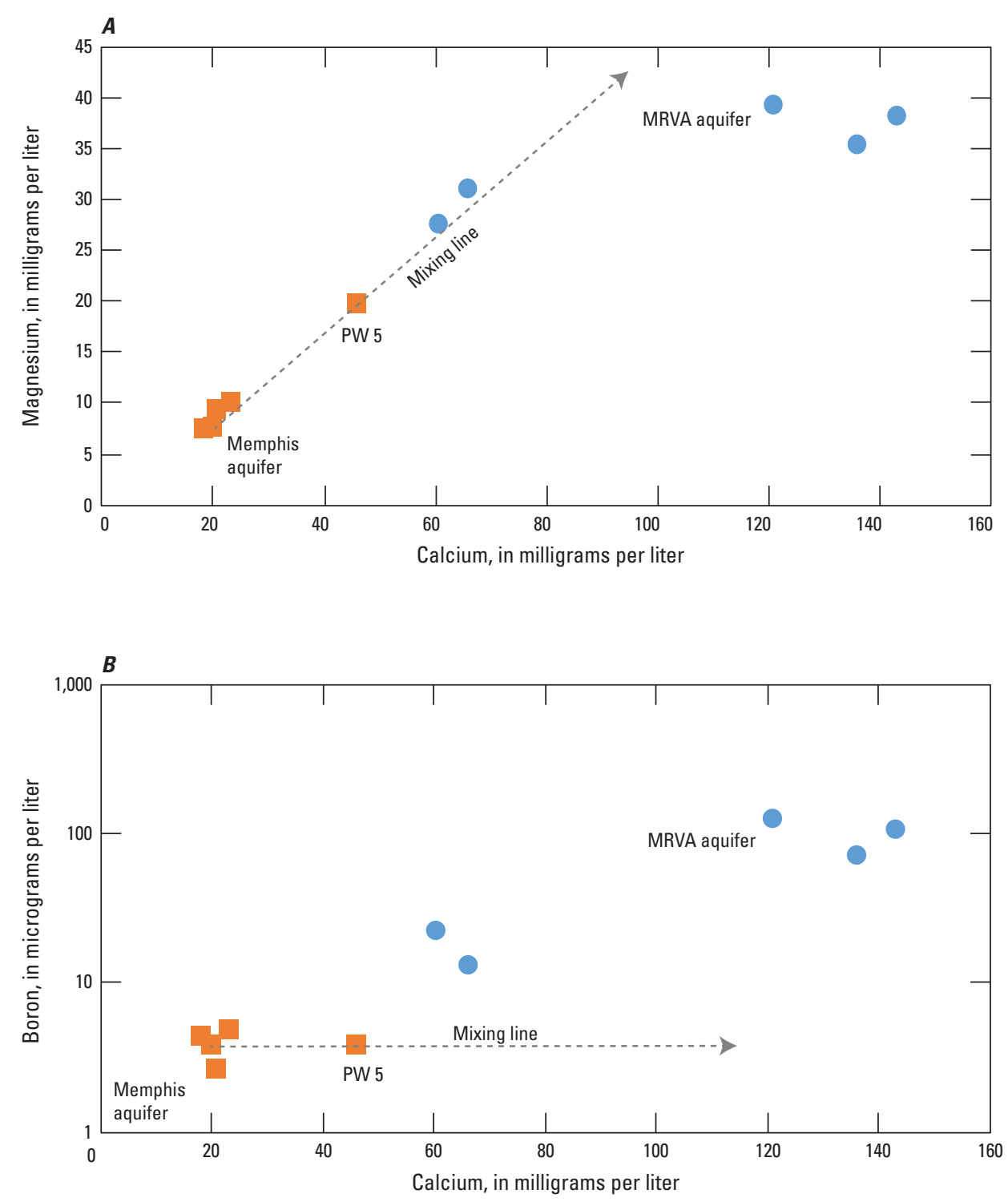

Figure 12. Hypothetical mixing line for groundwater samples collected from Memphis aquifer production wells PW 1 through PW 4 that are unaffected by leakage to production well PW 5 where alluvial water has moved into the Memphis aquifer at the Tennessee Valley Authority Allen Combined Cycle Plant, September 2017.

\section{Aquifer Test}

Results of the ACC Plant aquifer test indicate that a hydraulic connection exists between the Memphis aquifer and the MRVA aquifer near the TVA plants site. The apparent location of hydraulic connection is to the east-southeast of the plants and is coincident with a general eastward thinning of the confining unit and lowering in the altitude of the base of the MRVA aquifer as shown in the geophysical logs for production well PW 1 and stratigraphic test hole 212c (fig. 8). The following sections describe the effects of the test on water levels in the observation wells screened in the MRVA and Memphis aquifers.

\section{Memphis Aquifer}

Pre-test water-level measurements made in ACC Plant monitoring wells MW 1A, MW 3A, and MW 5A and MW $5 \mathrm{~B}$, and in co-located production wells PW 1, PW 3, and PW 5 indicate a downward vertical gradient of about $5 \mathrm{ft}$ between the MRVA and Memphis aquifers at the locations of wells PW 3 and PW 5, and a downward gradient of about $3 \mathrm{ft}$ at the location of well PW 1 prior to the start of the test. Production well PW 1 is located about 2,700 ft east of well PW 3 and about 1,300 ft southeast of well PW 5 (fig. 2). In 1995, a hydraulic gradient in the potentiometric surface of the Memphis aquifer of about $2.5 \mathrm{ft}$ per mile downward to the 
east was present in the TVA plants area (Kingsbury, 1996). Assuming the current gradient in the area is similar, about $0.6 \mathrm{ft}$ and $1.2 \mathrm{ft}$ of downward slope would be present in the Memphis aquifer from well PW 5 to PW 1 and from well PW 3 to PW 1, respectively, under nonpumping conditions locally. The primarily easterly slope in the potentiometric surface of the Memphis aquifer in the TVA plants area and an easterly gradient in the MRVA aquifer toward the apparent area of leakage to the east of the ACC Plant likely are the cause of the smaller difference between pre-test (static) water levels in wells PW 1 and MW 1A compared to the other well locations.

Maximum drawdown values observed in the Memphis aquifer in the five production wells and the three offsite observation wells during the aquifer test are shown in figure 13. Drawdowns ranged from 76 to $107 \mathrm{ft}$ (figs. 13 and 14), and specific capacities ranged from 12 to 16.4 gallons per minute per foot ([gal/min]/ft) (table 5) in the four pumped production wells. Drawdown values from the test were greater and specific-capacity values were less than values reported for the wells from initial well performance tests (Layne Christensen Company, written commun., 2017), but values were consistent among wells between the tests (table 5). The maximum drawdown measured in production well PW 2, which served as an onsite observation well during the test, was about $18 \mathrm{ft}$, and the drawdown appeared to stabilize in this well for the last 5 hours of the pumping period (fig. 14). The rate of declines measured in the four pumped production wells also slowed near the end of the pumping period.

Drawdown from the aquifer test was observed in two of the three offsite Memphis aquifer observation wells (wells
Sh:H-001 and Sh:H-013), indicating that the effects of the test extended beyond $1 \mathrm{mi}$ from the ACC Plant (figs. 13 and 15). The maximum estimated drawdowns induced by the test in wells Sh:H-001 and Sh:H-013 were about 1.6 and $1.3 \mathrm{ft}$, respectively (figs. 15A and $15 \mathrm{~B}$ ). In addition to the drawdown in well Sh:H-013 resulting from the test, the effects of daily pumping of a Memphis aquifer production well at an industrial site on President's Island, located about 2,500 ft west of observation well Sh:H-013, were seen in the water-level data collected from this well during the test. Based on separation of test-induced drawdown observed in well Sh:H-013 from that produced by pumping at the industrial site on President's Island during the test using the SeriesSEE program, an additional $1.5 \mathrm{ft}$ of drawdown attributed to the industrial site was estimated in well Sh:H-013 (fig. 15B). Water levels declined about $0.03 \mathrm{ft}$ in well Ar:H-002 from the start to the end of the test pumping period based on the continuous water-level data collected in this well (fig. 15C). Water levels monitored in well Ar:H-002 show a downward trend for at least several days prior to the start of the test. Given that no significant withdrawals from the Memphis aquifer are known to occur near well Ar:H-002, the water-level data collected from this well probably are indicative of ambient conditions in the Memphis aquifer in the TVA plants area. The waterlevel data for this well also indicate the effect of semi-diurnal Earth tides. Given the distance from the ACC Plant to this well (about $4 \mathrm{mi}$ ) and the downward trend in water levels observed in this well before and during the test, effects of the test are unlikely to have extended to this well.

Table 5. Pumping rates, drawdown values, and specific capacities for Memphis aquifer production wells during the aquifer test, October 3-4, 2017, and from performance tests, June 15-21, 2016, Tennessee Valley Authority Allen Combined Cycle Plant.

[Performance-test data from Layne Christensen Company, written commun., 2017; ft, feet; gal/min, gallons per minute; (gal/min)/ft, gallons per minute per foot]

\begin{tabular}{|c|c|c|c|c|c|c|}
\hline \multirow[b]{2}{*}{$\begin{array}{c}\text { Production well } \\
\text { (see figure } 2 \\
\text { for location) }\end{array}$} & \multicolumn{3}{|c|}{ Aquifer test, October 3-4, 2017} & \multicolumn{3}{|c|}{ Performance tests, June 15-21, 2016} \\
\hline & $\begin{array}{c}\text { Average } \\
\text { pumping rate } \\
\text { (gal/min) }\end{array}$ & $\begin{array}{c}\text { Drawdown } \\
\text { (ft) }\end{array}$ & $\begin{array}{c}\text { Specific } \\
\text { capacity } \\
\text { ([gal/min]/ft) }\end{array}$ & $\begin{array}{l}\text { Pumping } \\
\text { rate } \\
\text { (gal } / \mathrm{min} \text { ) }\end{array}$ & $\begin{array}{c}\text { Drawdown } \\
\text { (ft) }\end{array}$ & $\begin{array}{c}\text { Specific } \\
\text { capacity } \\
\text { ([gal/min]/ft) }\end{array}$ \\
\hline PW 1 & 1,243 & 93 & 13.4 & 1,280 & 82 & 15.6 \\
\hline PW 2 & $*$ & $18 *$ & * & 1,303 & 74 & 17.6 \\
\hline PW 3 & 1,250 & 76 & 16.4 & 1,304 & 65 & 20.1 \\
\hline PW 4 & 1,284 & 107 & 12.0 & 1,338 & 95 & 14.1 \\
\hline PW 5 & 1,262 & 89 & 14.2 & 1,260 & 76 & 16.6 \\
\hline
\end{tabular}

${ }^{*}$ Well not pumped during test. 


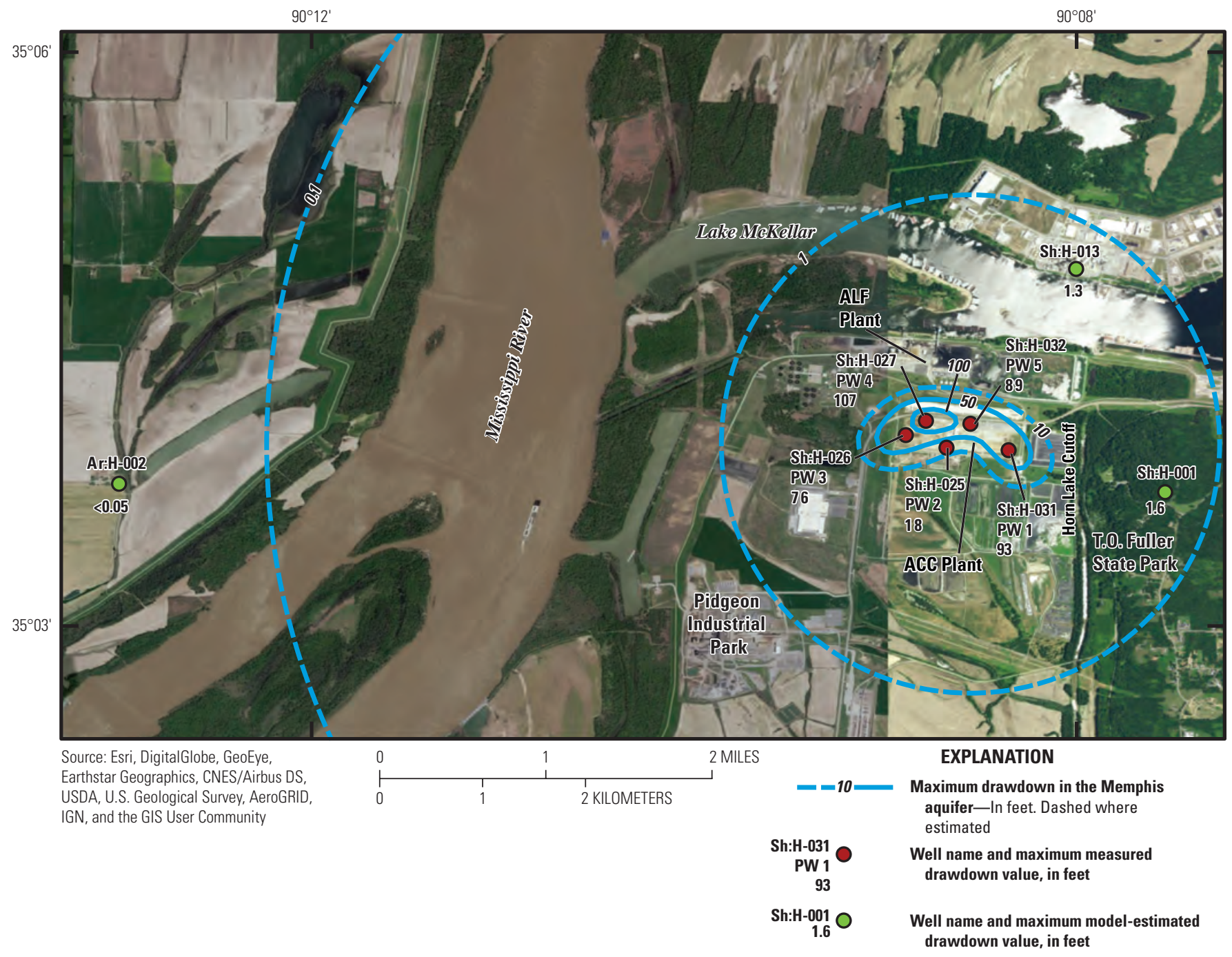

Figure 13. Maximum drawdown measured in the Memphis aquifer production wells and maximum estimated drawdown in Memphis aquifer observation wells, Tennessee Valley Authority Allen Combined Cycle Plant aquifer test, October 3-4, 2017. 


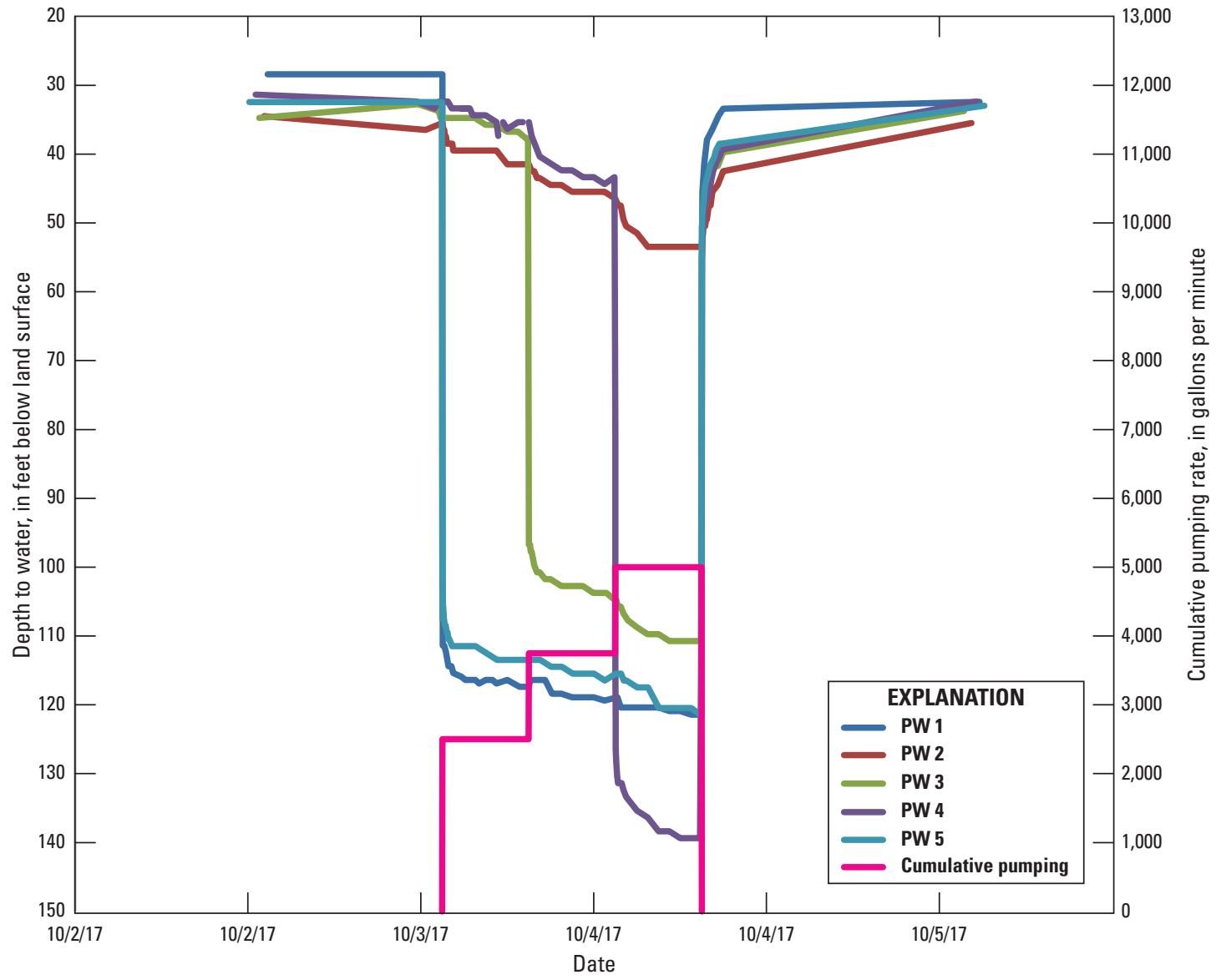

Figure 14. Measured drawdown and cumulative pumping rates in Memphis aquifer production wells, Tennessee Valley Authority Allen Combined Cycle Plant aquifer test, October 3-4, 2017. 

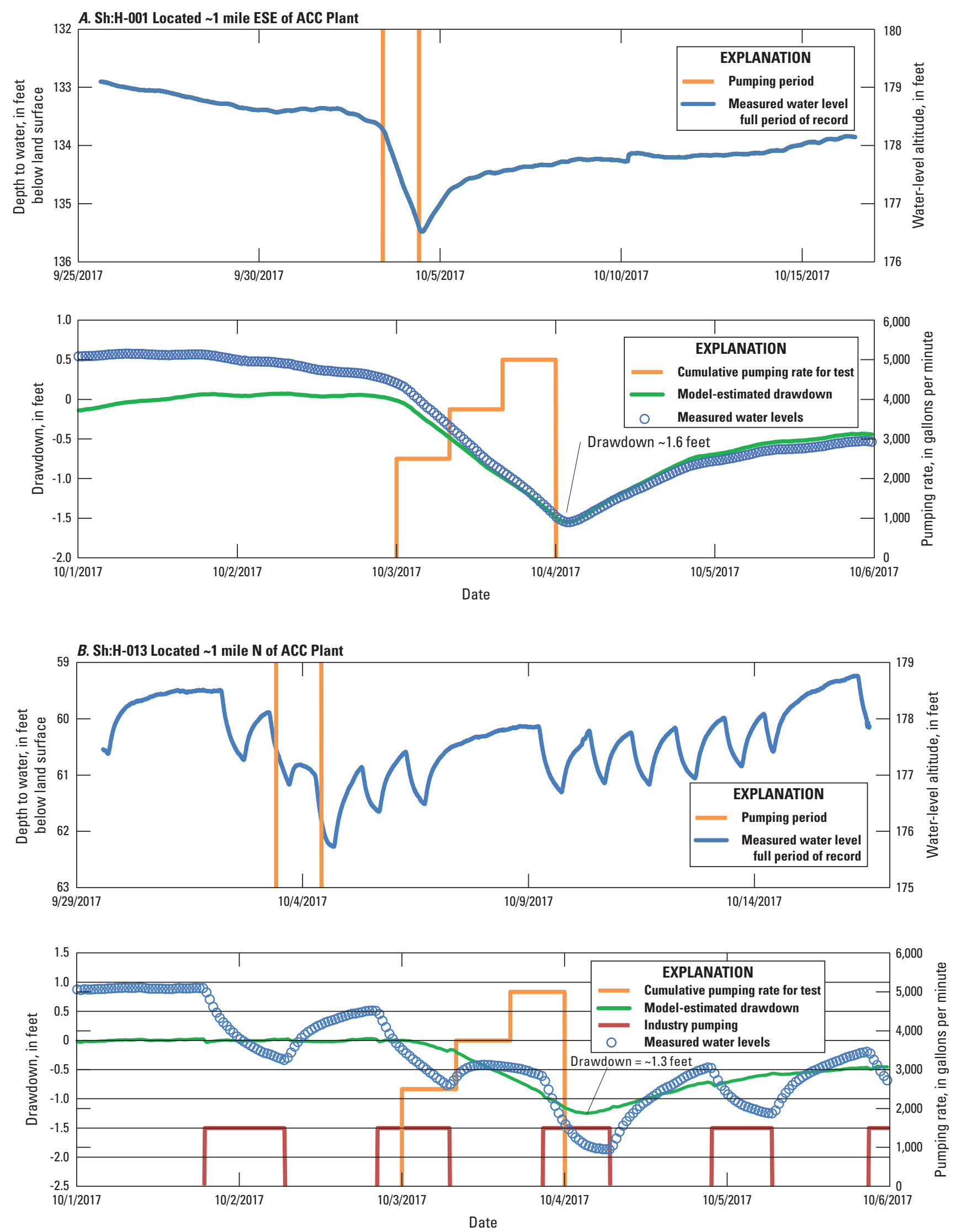

Figure 15. Measured water levels and estimated drawdown in Memphis aquifer observation wells $(A)$ Sh:H-001, $(B)$ Sh:H-013, and (C) Ar:H-002, Tennessee Valley Authority Allen Combined Cycle Plant aquifer test, October 3-4, 2017. 

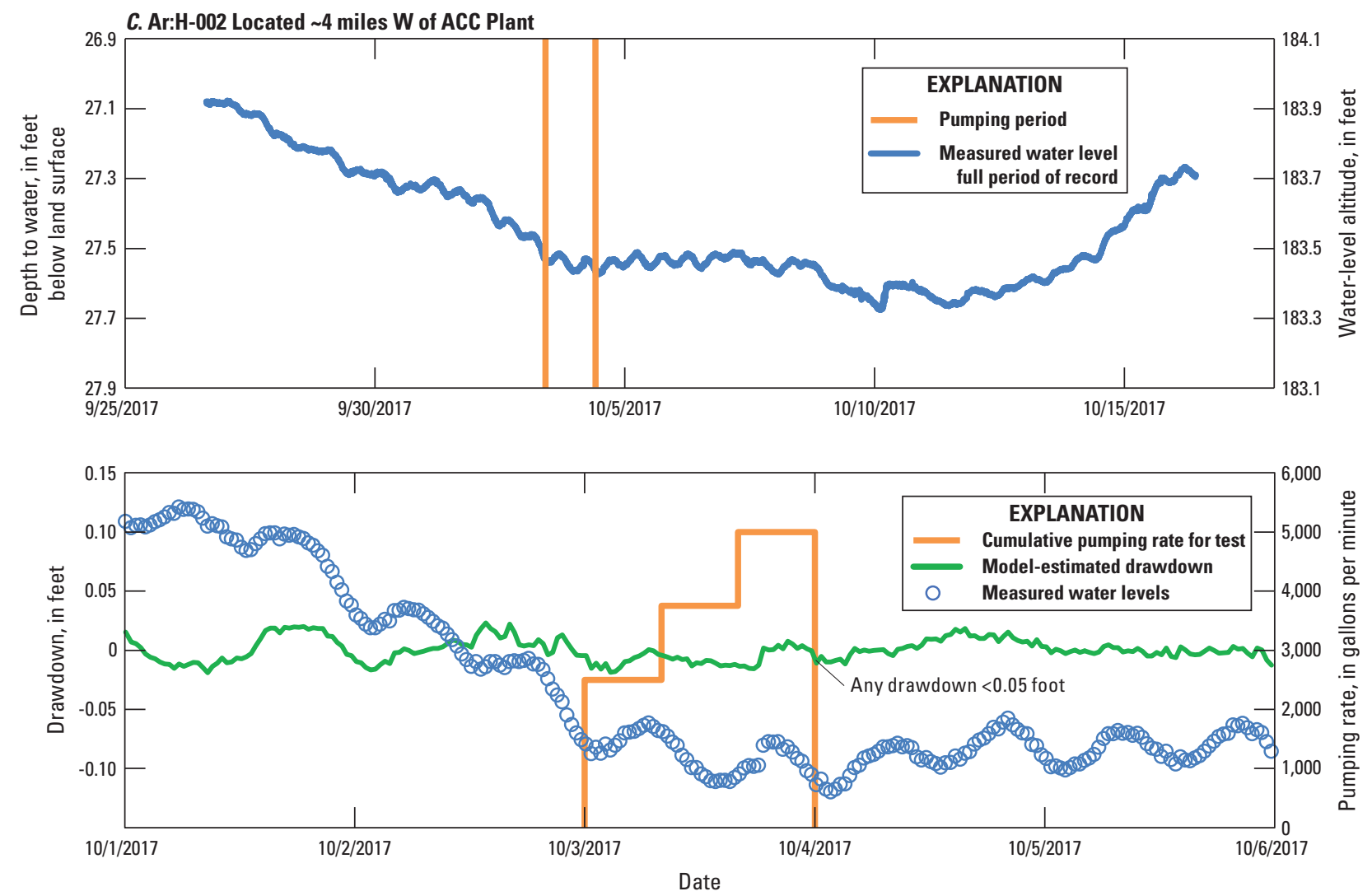

Figure 15. Measured water levels and estimated drawdown in Memphis aquifer observation wells $(A)$ Sh:H-001, $(B)$ Sh:H-013, and $(C)$ Ar:H-002, Tennessee Valley Authority Allen Combined Cycle Plant aquifer test, October 3-4, 2017. - Continued

The magnitude of drawdown observed in offsite Memphis aquifer observation well Sh:H-001 (about $1.6 \mathrm{ft}$ at end of pumping) provides a reliable estimate of drawdown resulting from the aquifer test at a distance of about $1 \mathrm{mi}$ from the ACC Plant. Drawdown of this magnitude at about $1 \mathrm{mi}$ from the plant is similar to the results of the scenario simulation conducted for the TVA with the MERAS groundwater model (Haugh, 2016). The extent and uninterrupted character of drawdown recorded in well Sh:H-001 suggest that the flux of groundwater from the MRVA aquifer to the Memphis aquifer in the area of leakage was not a substantial component of the water pumped during the test. No accurate estimate of the flux of water draining from the MRVA aquifer under natural or pumped conditions can be made until the nature and extent of the area of leakage is better known.

\section{MRVA Aquifer}

Although drawdown from the aquifer test was observed in several of the MRVA aquifer monitoring wells at both TVA plants, continuous data collected from monitoring wells unaffected by the test show that water levels in the MRVA aquifer were declining at a rate of about $0.2 \mathrm{ft} / \mathrm{d}$ from the beginning of October through completion of the test. The SeriesSEE program was used to remove this trend of waterlevel decline in the MRVA aquifer to produce estimates of drawdown in monitoring wells in the aquifer resulting solely from the test.

Estimated values of drawdown in the MRVA aquifer from the test ranged from about $0.5 \mathrm{ft}$ at the ALF Plant to less than $0.1 \mathrm{ft}$ in wells at multiple locations at both plants (table 6; figs. 16 and 17). The largest drawdown was to the southeast of the ALF Plant and along the eastern side of the ACC Plant (figs. 16A, 16E, and 17; monitoring wells MW 1A, MW 202A, MW 202B, and MW 212A). Estimated drawdown generally decreased to the north and west. Water-level data collected from wells along the northern side of the ALF Plant show little to no obvious response to pumping during the test, and water levels are similar to and fluctuate in unison with the stage of Lake McKellar estimated from streamgage 07032000 (figs. 16G, 16H, and 17; wells MW 204A and MW 204B). 
Table 6. Model drawdown estimates for monitoring wells screened in the Mississippi River Valley alluvial aquifer at the Tennessee Valley Authority Allen Fossil and Allen Combined Cycle Plants, Tennessee Valley Authority Allen Combined Cycle Plant aquifer test, October 3-4, 2017.

[Not detected (ND), inconclusive (I), and detected (D) indicate relative certainty of drawdown greater than 0.05 foot. DP, deep; I, intermediate; $\mathrm{S}$, shallow; <, less than]

\begin{tabular}{|c|c|c|c|c|}
\hline $\begin{array}{l}\text { Well } \\
\text { field } \\
\text { ID (see } \\
\text { figure } 2 \text { for } \\
\text { location) }\end{array}$ & $\begin{array}{l}\text { Interval } \\
\text { screened }\end{array}$ & $\begin{array}{c}\text { Estimated } \\
\text { drawdown } \\
\text { from aquifer } \\
\text { test } \\
\text { (feet) }\end{array}$ & $\begin{array}{c}\text { Estimated } \\
\text { drawdown } \\
\text { from other } \\
\text { pumping } \\
\text { (feet) }\end{array}$ & Remarks \\
\hline MW 1A & DP & 0.33 (D) & 0 (ND) & \\
\hline MW 3A & DP & $0.15(\mathrm{I})$ & 0 (I) & Possible delayed drawdown \\
\hline MW 5A & DP & 0.2 (D) & 0.1 (D) & \\
\hline MW 5B & I & 0.15 (D) & $0.1(\mathrm{D})$ & \\
\hline MW 201 & S & 0.25 (D) & 0.15 (D) & \\
\hline MW 201A & DP & $0.3(\mathrm{D})$ & $0.15(\mathrm{D})$ & \\
\hline MW 201B & I & $0.3(\mathrm{D})$ & 0.15 (D) & \\
\hline MW 202 & S & $0.02(\mathrm{I})$ & $0.05(\mathrm{I})$ & Possible perched water \\
\hline MW 202A & DP & $0.5(\mathrm{D})$ & $0.15(\mathrm{D})$ & \\
\hline MW 202B & I & 0.5 (D) & $0.15(\mathrm{D})$ & \\
\hline MW 203 & S & $0.02(\mathrm{I})$ & 0.08 (D) & \\
\hline MW 203A & DP & $0.02(\mathrm{I})$ & $0.15(\mathrm{D})$ & \\
\hline MW 203B & I & $0.02(\mathrm{I})$ & 0.15 (D) & \\
\hline MW 204 & $\mathrm{~S}$ & 0.08 (D) & $0.05(\mathrm{I})$ & Possible perched water \\
\hline MW 204A & DP & $0.05(\mathrm{I})$ & 0.05 (I) & \\
\hline MW 204B & I & $0.05(\mathrm{I})$ & 0.07 (D) & \\
\hline MW 205 & S & 0.07 (D) & 0.15 (D) & \\
\hline MW 205A & DP & 0.07 (D) & 0.08 (D) & \\
\hline MW 205B & I & 0.07 (D) & 0.08 (D) & \\
\hline MW 206 & S & 0.04 (I) & 0.05 (I) & \\
\hline MW 210 & S & $0.02(\mathrm{I})$ & $0.1(\mathrm{D})$ & Possible delayed drawdown \\
\hline MW 210A & DP & $0.02(\mathrm{I})$ & $0.14(\mathrm{D})$ & Possible delayed drawdown \\
\hline MW 212 & S & $0.01(\mathrm{I})$ & $0.03(\mathrm{I})$ & Possible perched water \\
\hline MW 212A & DP & 0.49 (D) & $0.08(\mathrm{D})$ & \\
\hline MW 213 & S & 0.25 (D) & 0.08 (D) & \\
\hline MW 214 & S & 0.1 (D) & 0.15 (D) & \\
\hline MW 214A & DP & 0.06 (D) & $0.15(\mathrm{D})$ & \\
\hline MW 214B & I & 0.07 (D) & $0.15(\mathrm{D})$ & \\
\hline MW 215 & S & 0 (ND) & 0.02 (I) & \\
\hline MW 216 & S & 0.28 (D) & 0.1 (D) & \\
\hline MW P-4 & I & $<0.05$ (I) & $0.2(\mathrm{I})$ & \\
\hline MW P-4S & $\mathrm{S}$ & $<0.05$ (I) & $0.15(\mathrm{I})$ & \\
\hline
\end{tabular}



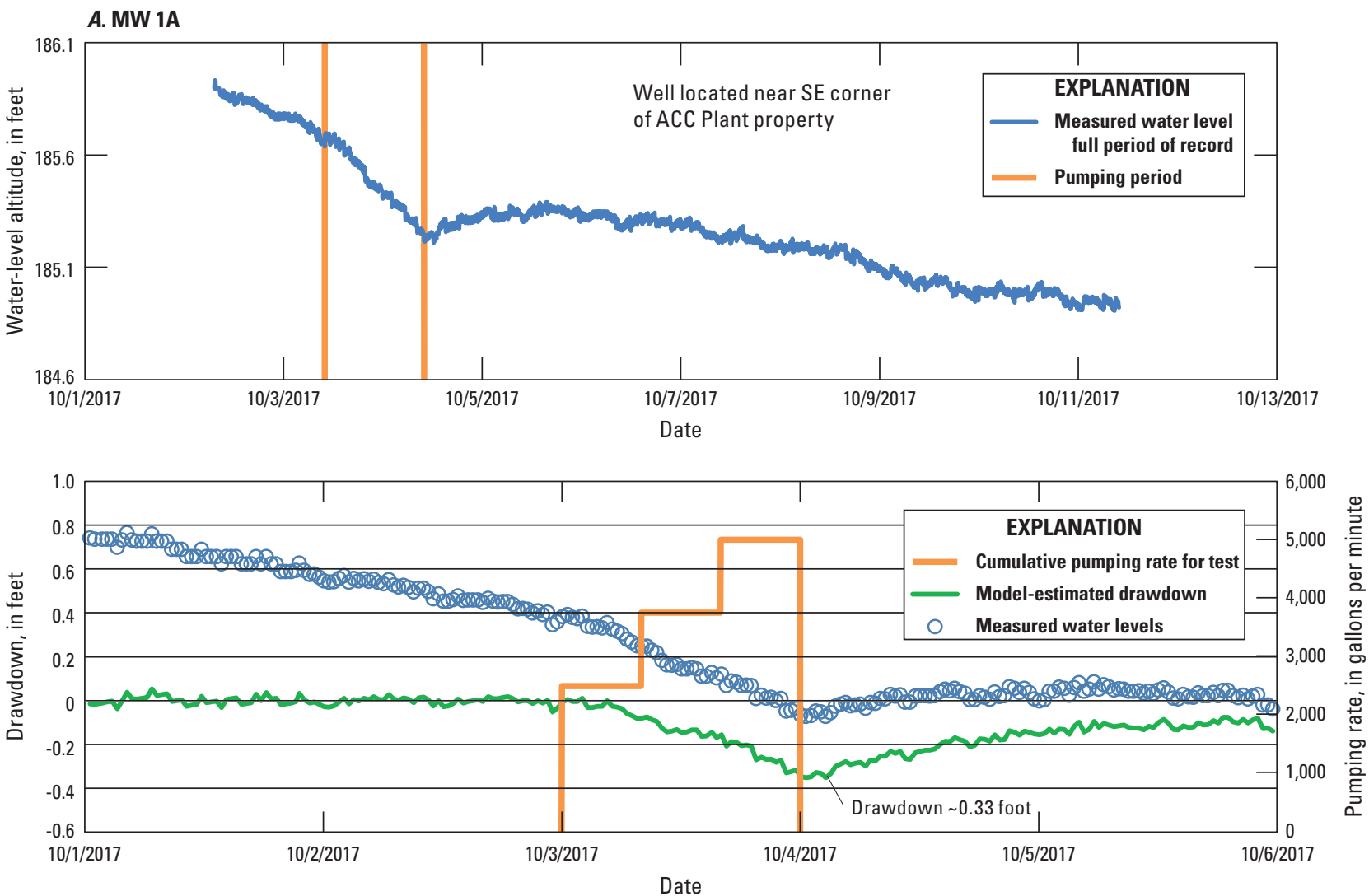

B. MW $3 A$
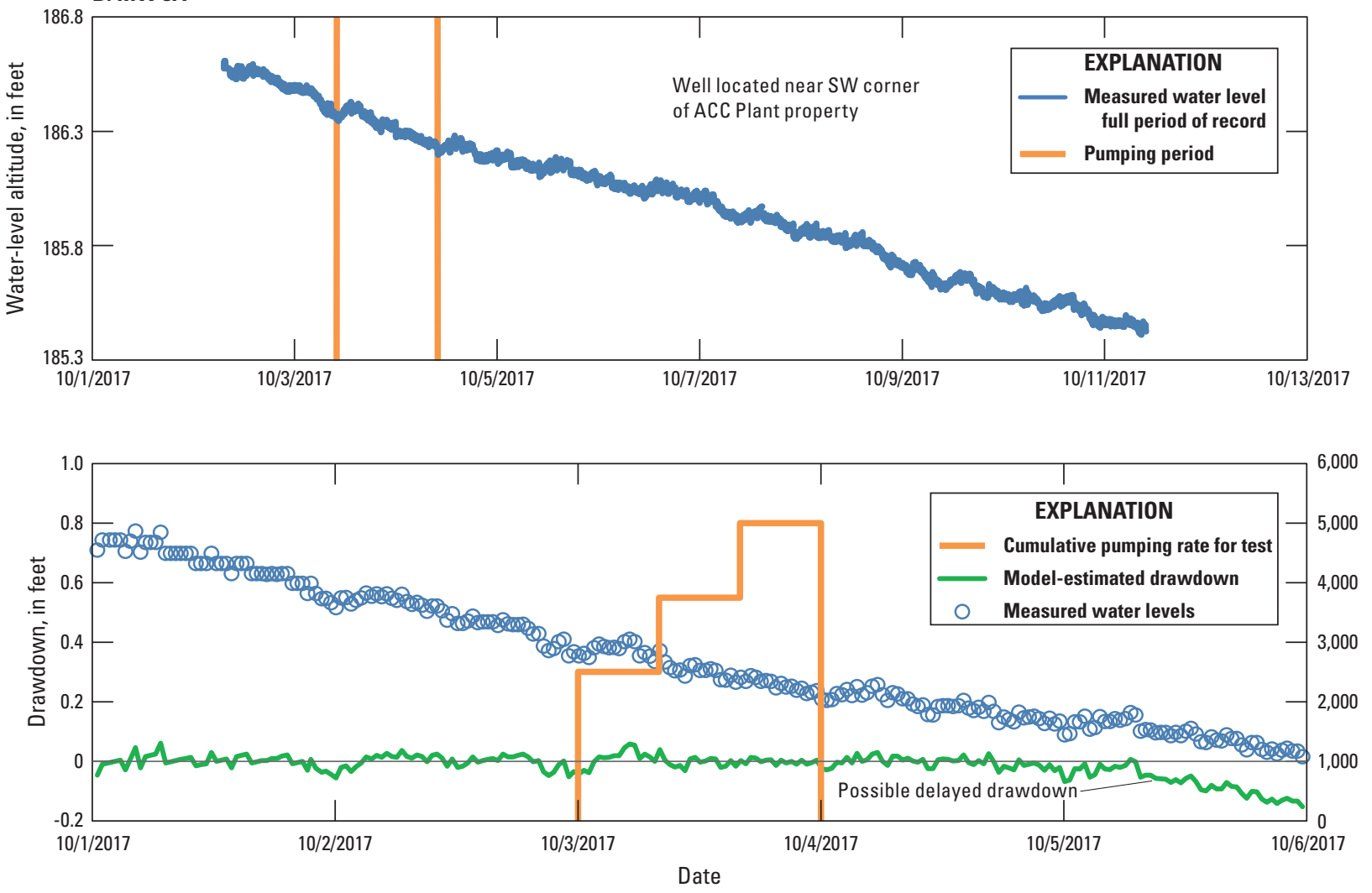

Figure 16. Measured water levels and estimated drawdown in selected Mississippi River Valley alluvial aquifer monitoring wells $(A)$ MW 1A, $(B)$ MW 3A, $(C)$ MW 5A and MW 5B at Allen Combined Cycle Plant; $(D)$ MW 202, (E) MW 202A and MW 202B, (F) MW 210 and MW 210A, and (G) MW 204A and MW 204B at Allen Fossil Plant; and (H) stage of the Mississippi River at Memphis (USGS station number 07032000, Mississippi River at Memphis, TN), Tennessee Valley Authority Allen Combined Cycle Plant aquifer test, October 3-4, 2017. 

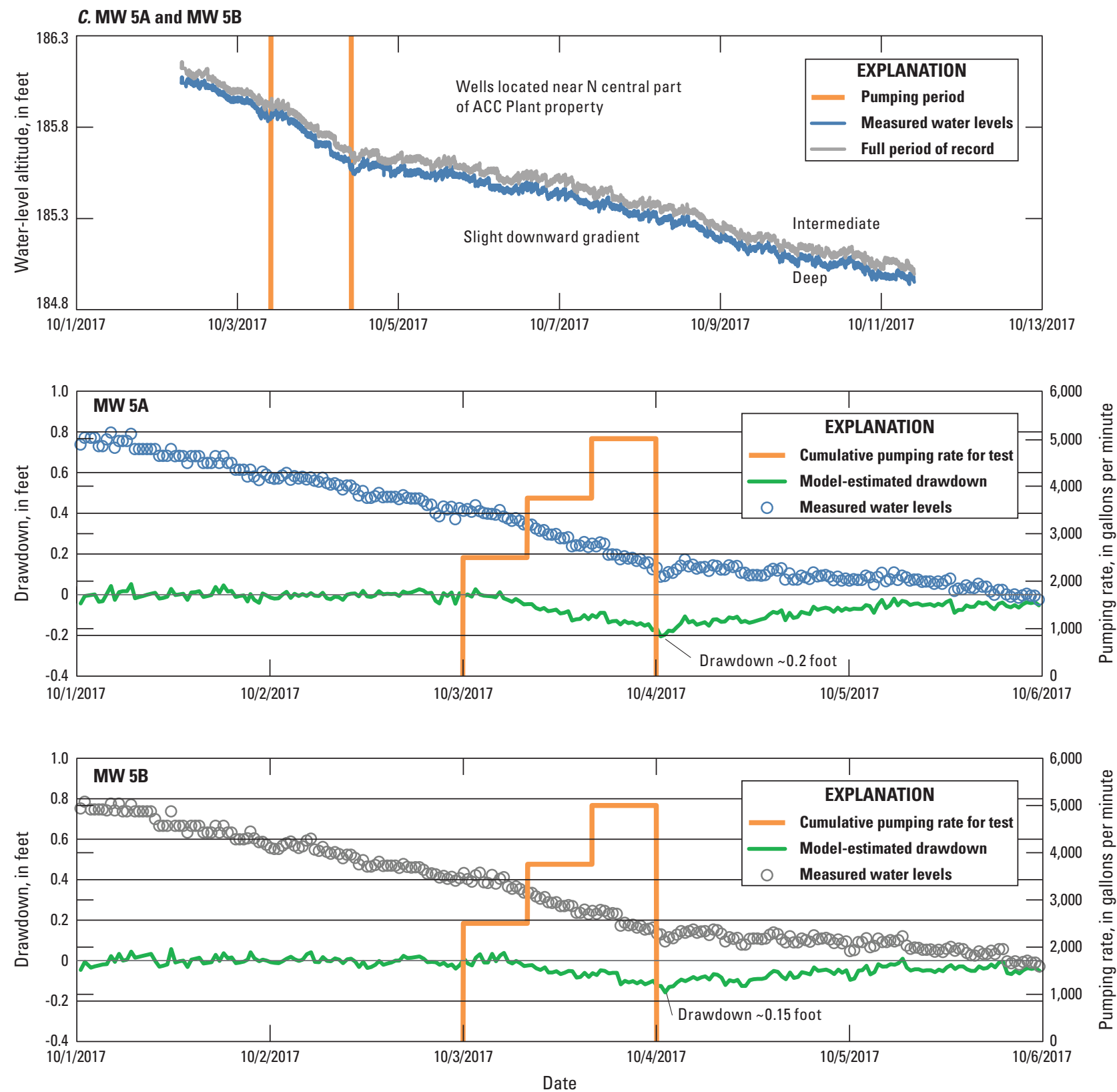

Figure 16. Measured water levels and estimated drawdown in selected Mississippi River Valley alluvial aquifer monitoring wells $(A)$ MW 1A, $(B)$ MW 3A, (C) MW 5A and MW 5B at Allen Combined Cycle Plant; $(D)$ MW 202, (E) MW 202A and MW 202B, (F) MW 210 and MW 210A, and (G) MW 204A and MW 204B at Allen Fossil Plant; and (H) stage of the Mississippi River at Memphis (USGS station number 07032000, Mississippi River at Memphis, TN), Tennessee Valley Authority Allen Combined Cycle Plant aquifer test, October 3-4, 2017.-Continued 

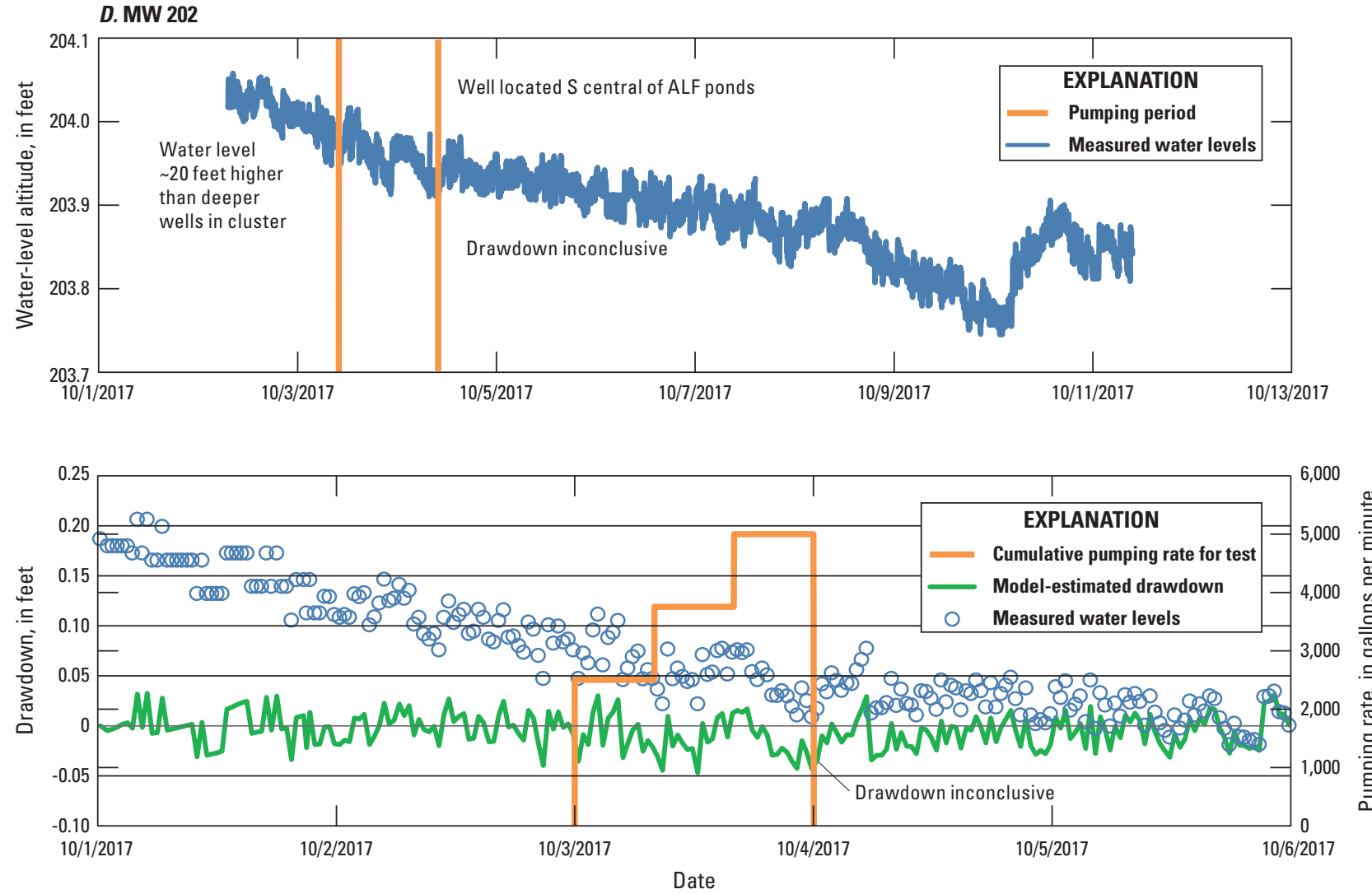

Figure 16. Measured water levels and estimated drawdown in selected Mississippi River Valley alluvial aquifer monitoring wells $(A)$ MW 1A, $(B)$ MW 3A, $(C)$ MW 5A and MW 5B at Allen Combined Cycle Plant; (D) MW 202, (E) MW 202A and MW 202B, (F) MW 210 and MW 210A, and (G) MW 204A and MW 204B at Allen Fossil Plant; and (H) stage of the Mississippi River at Memphis (USGS station number 07032000, Mississippi River at Memphis, TN), Tennessee Valley Authority Allen Combined Cycle Plant aquifer test, October 3-4, 2017.-Continued 
E. MW 202A and MW 202B
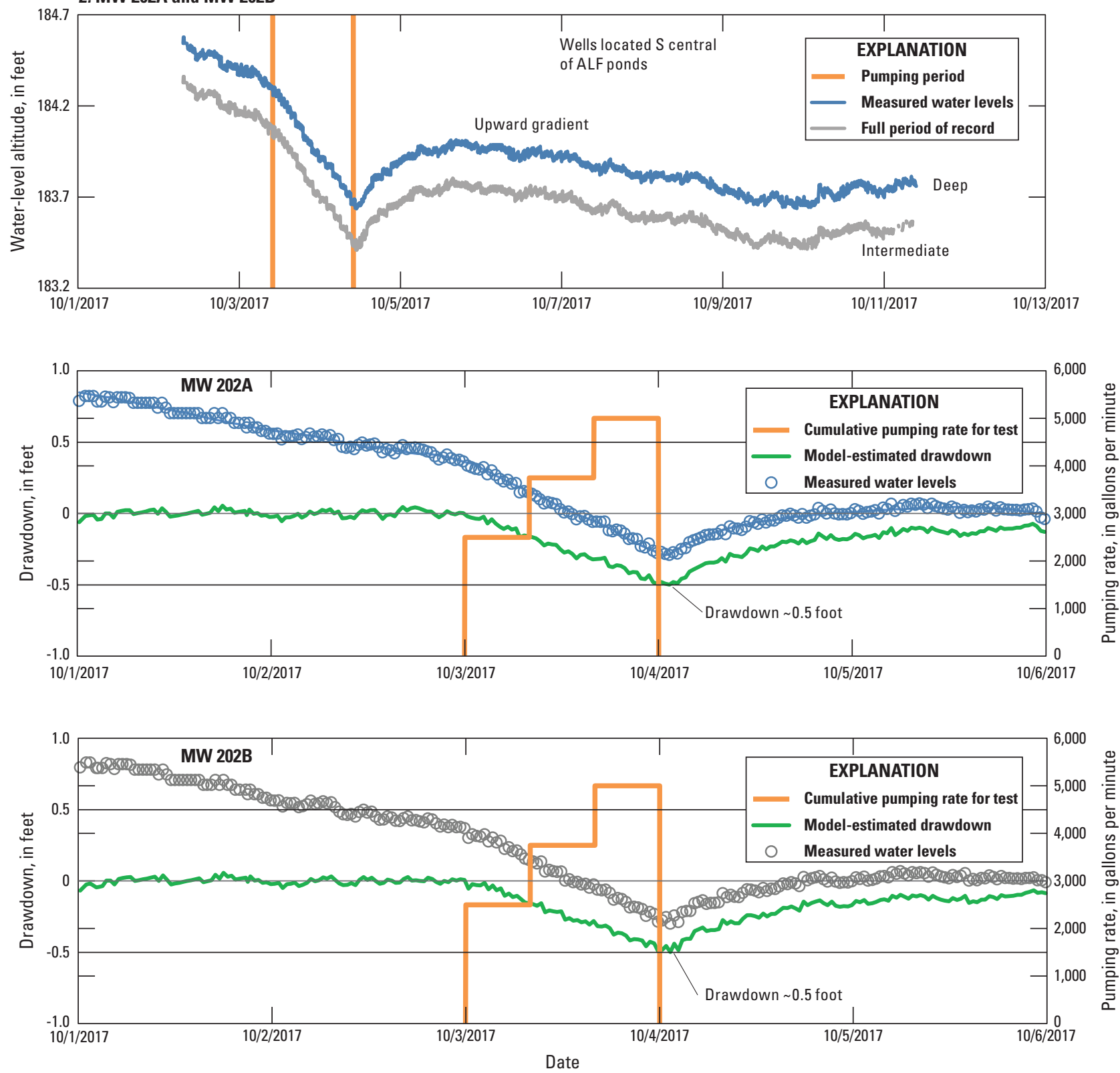

Figure 16. Measured water levels and estimated drawdown in selected Mississippi River Valley alluvial aquifer monitoring wells $(A)$ MW 1A, $(B)$ MW 3A, $(C)$ MW 5A and MW 5B at Allen Combined Cycle Plant; $(D)$ MW 202, (E) MW 202A and MW 202B, (F) MW 210 and MW 210A, and (G) MW 204A and MW 204B at Allen Fossil Plant; and (H) stage of the Mississippi River at Memphis (USGS station number 07032000, Mississippi River at Memphis, TN), Tennessee Valley Authority Allen Combined Cycle Plant aquifer test, October 3-4, 2017.—Continued 

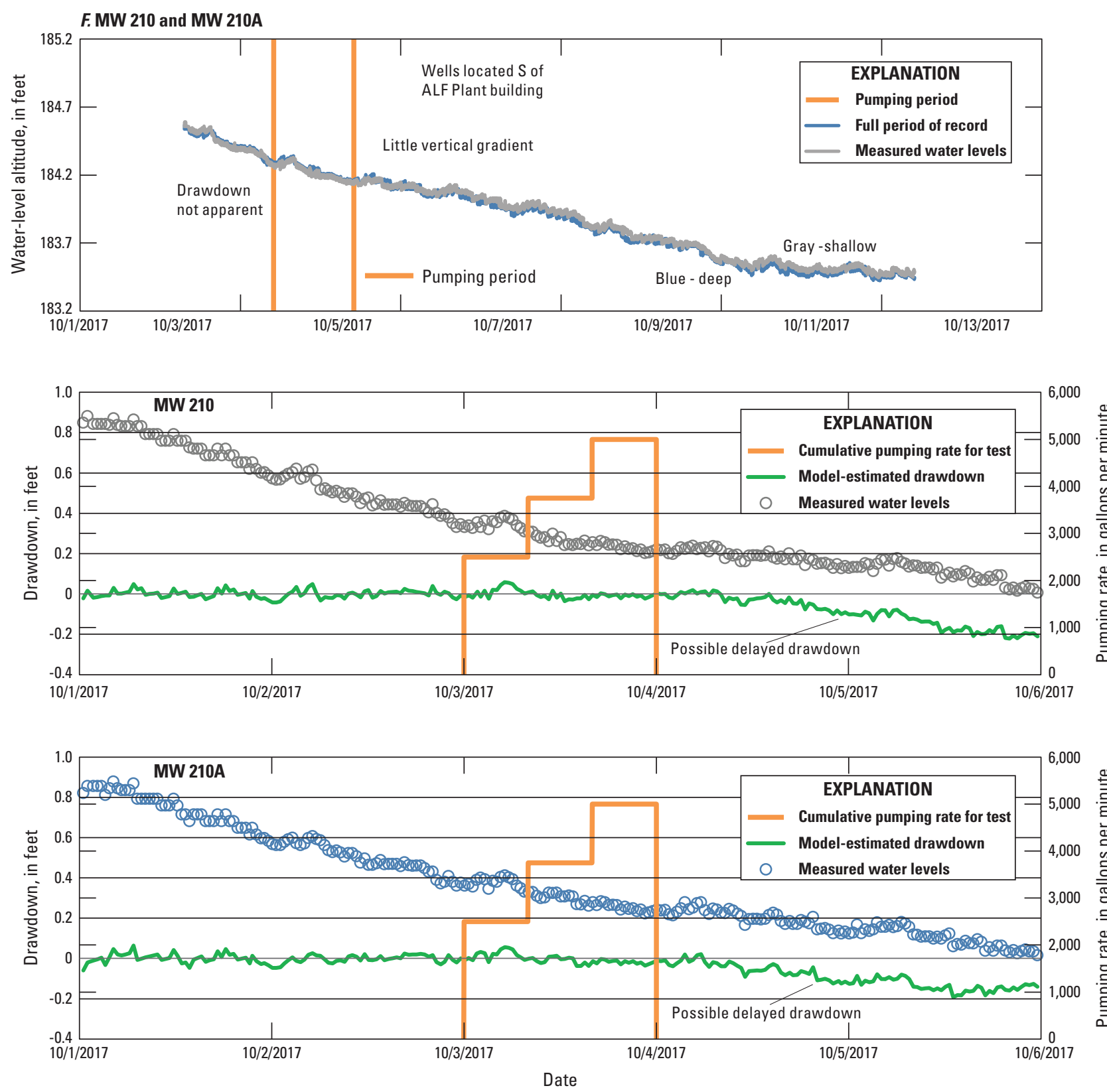

Figure 16. Measured water levels and estimated drawdown in selected Mississippi River Valley alluvial aquifer monitoring wells $(A)$ MW 1A, $(B)$ MW 3A, $(C)$ MW $5 A$ and MW 5B at Allen Combined Cycle Plant; $(D)$ MW 202, (E) MW 202A and MW 202B, (F) MW 210 and MW 210A, and (G) MW 204A and MW 204B at Allen Fossil Plant; and (H) stage of the Mississippi River at Memphis (USGS station number 07032000, Mississippi River at Memphis, TN), Tennessee Valley Authority Allen Combined Cycle Plant aquifer test, October 3-4, 2017.-Continued 

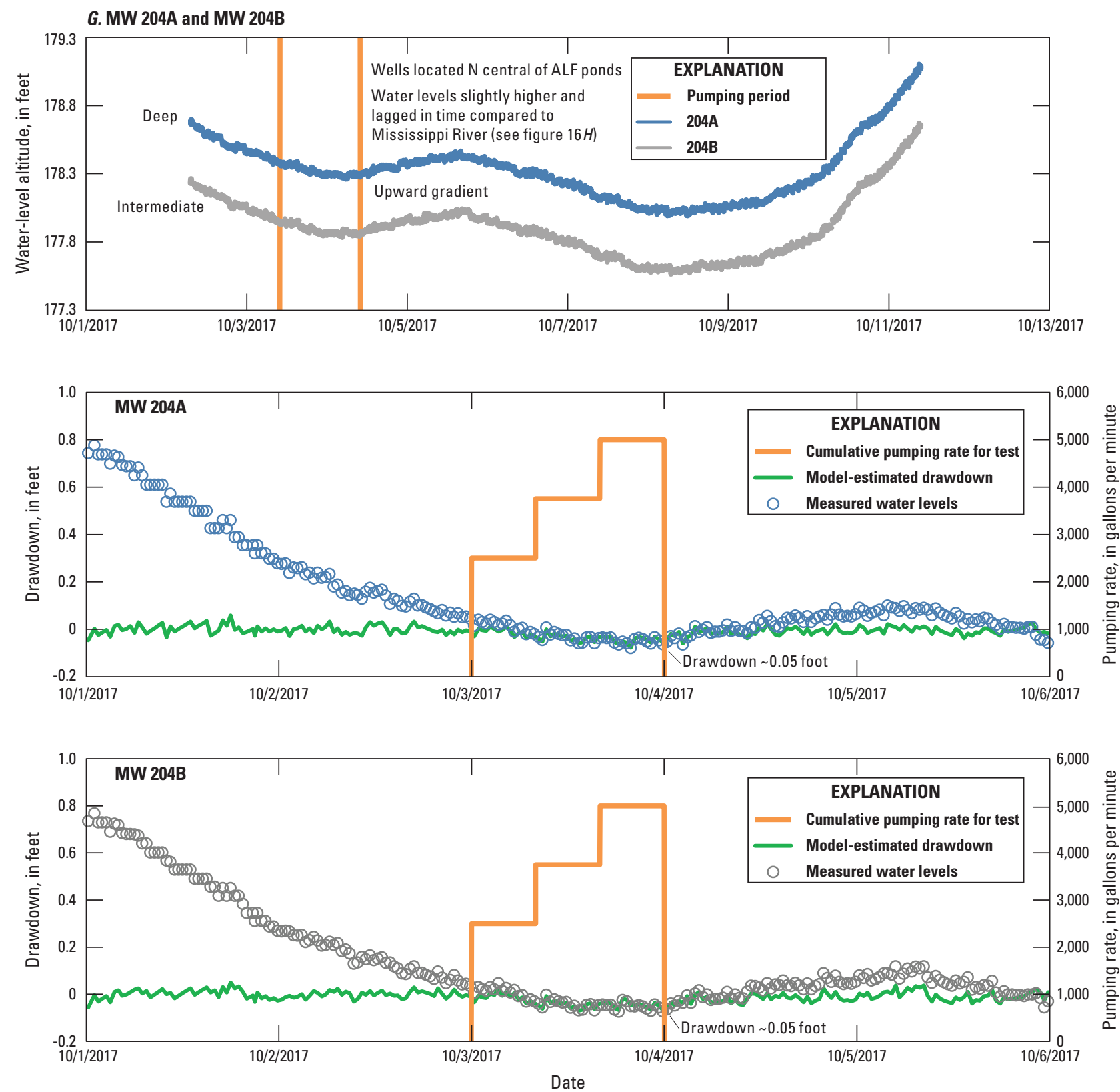

Figure 16. Measured water levels and estimated drawdown in selected Mississippi River Valley alluvial aquifer monitoring wells $(A)$ MW 1A, $(B)$ MW 3A, $(C)$ MW 5A and MW 5B at Allen Combined Cycle Plant; $(D)$ MW 202, (E) MW 202A and MW 202B, (F) MW 210 and MW 210A, and (G) MW 204A and MW 204B at Allen Fossil Plant; and (H) stage of the Mississippi River at Memphis (USGS station number 07032000, Mississippi River at Memphis, TN), Tennessee Valley Authority Allen Combined Cycle Plant aquifer test, October 3-4, 2017.-Continued 


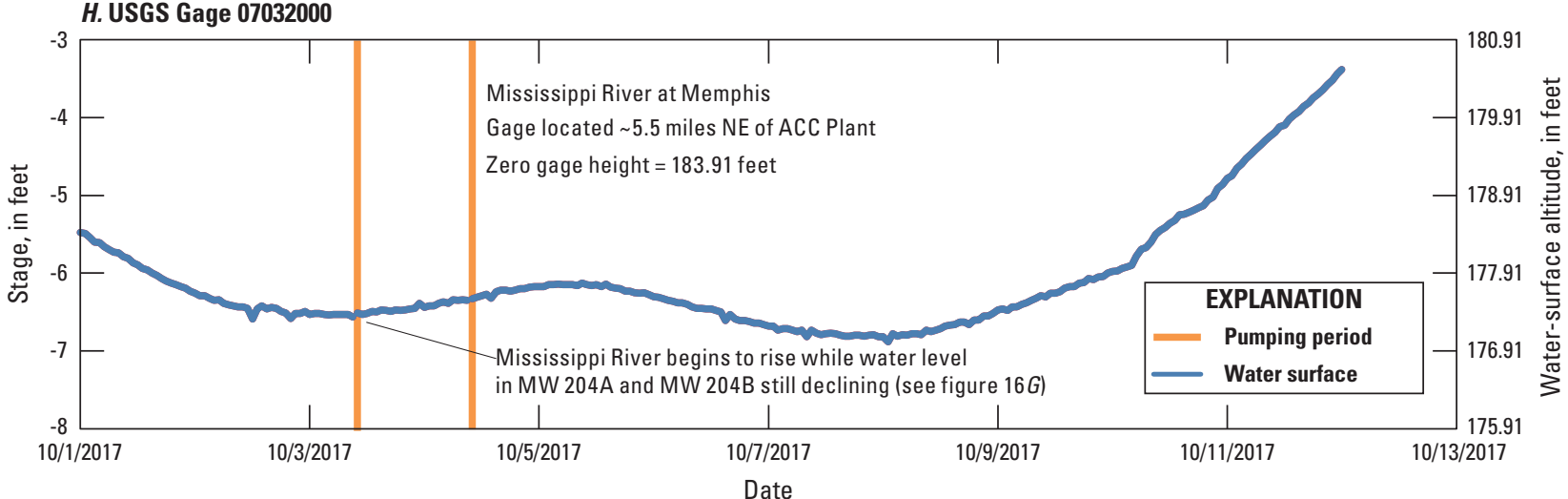

Figure 16. Measured water levels and estimated drawdown in selected Mississippi River Valley alluvial aquifer monitoring wells $(A)$ MW 1A, $(B)$ MW 3A, $(C)$ MW 5A and MW 5B at Allen Combined Cycle Plant; $(D)$ MW 202, (E) MW 202A and MW 202B, (F) MW 210 and MW 210A, and (G) MW 204A and MW 204B at Allen Fossil Plant; and $(H)$ stage of the Mississippi River at Memphis (USGS station number 07032000, Mississippi River at Memphis, TN), Tennessee Valley Authority Allen Combined Cycle Plant aquifer test, October 3-4, 2017.-Continued

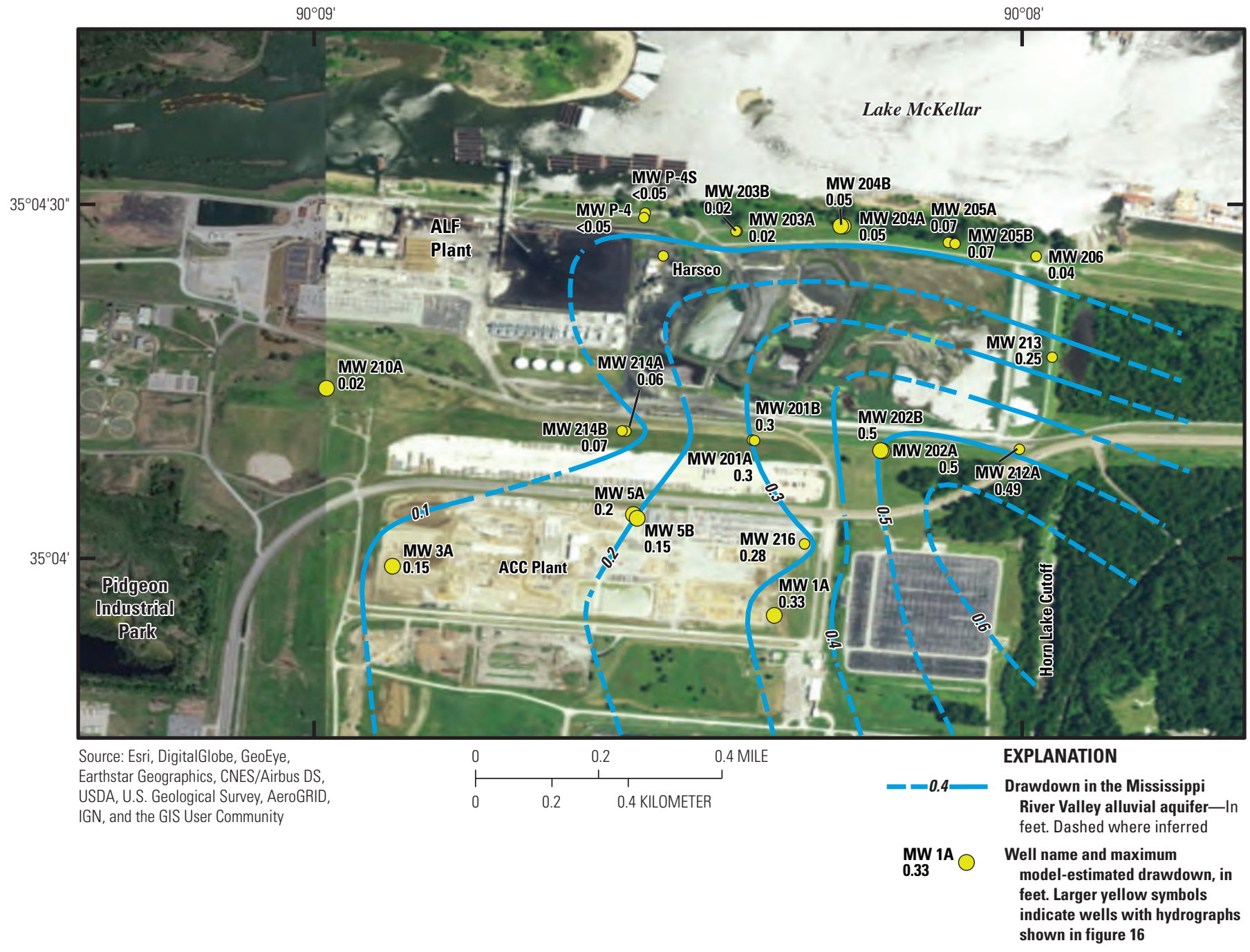

Figure 17. Estimated drawdown in selected monitoring wells screened in the Mississippi River Valley alluvial aquifer, Tennessee Valley Authority Allen Combined Cycle Plant aquifer test, October 3-4, 2017. 
The largest drawdown in the MRVA aquifer during the test occurred in monitoring wells MW 202A (deep) and MW 202B (intermediate) located in the southeastern part of the ALF Plant (figs. 16E and 17). Continuous water-level data collected from these wells indicate an upward gradient from the lower to the middle part of the MRVA aquifer at this location before, during, and after the test. Although the upward hydraulic gradient between the wells persisted during the test, the gradient decreased during the pumping period (fig. 16E), indicating that the effects of pumping extended to and altered the existing gradient between the lower and middle parts of the MRVA aquifer at this location.

Pre-test and late pumping period water-level data indicate that hydraulic gradients in the intermediate and deep parts of the MRVA aquifer beneath most of the TVA plants area were downward to the north toward Lake McKellar before the test and remained so throughout the test (figs. 18 and 19). These results, along with upward vertical gradients between water levels in paired monitoring wells screened in the intermediate and deep parts of the MRVA aquifer at some locations at the ALF Plant (figs. 16E and 16G), indicate that Lake McKellar likely was the point of discharge of groundwater in the aquifer beneath most of the TVA plants area prior to, during, and after the test. These observations indicate that the induced drawdown from the test did not substantially alter the northward direction of groundwater flow in the MRVA aquifer at most locations at the TVA plants site. Water-level data collected for the test from monitoring wells in the eastern and southeastern parts of the TVA plants area indicate an easterly and convergent component of flow in the MRVA aquifer under both pre-test (nonpumping) and late pumpingperiod conditions in the Memphis aquifer (figs. 18 and 19). It should be noted that the test was conducted under low-stage conditions in Lake McKellar and presumably corresponding low water-level conditions in the MRVA aquifer, and that the results are not necessarily representative of how the flow regime in the aquifer would respond under higher water-level conditions, with or without pumping from the Memphis aquifer locally.

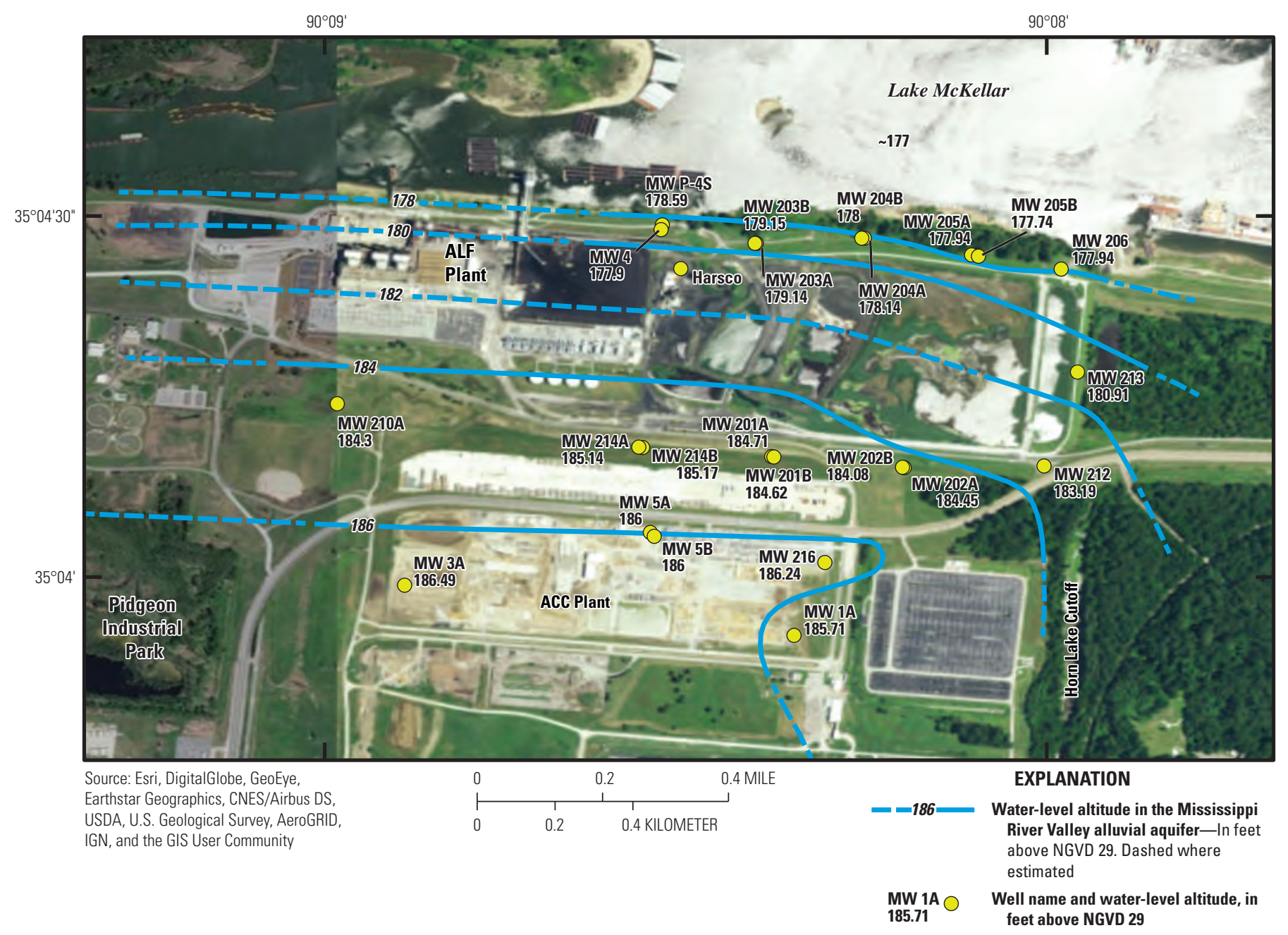

Figure 18. Pre-test water-level altitudes in the Mississippi River alluvial aquifer and stage of Lake McKellar, Tennessee Valley Authority Allen Combined Cycle Plant aquifer test, October 3-4, 2017. 


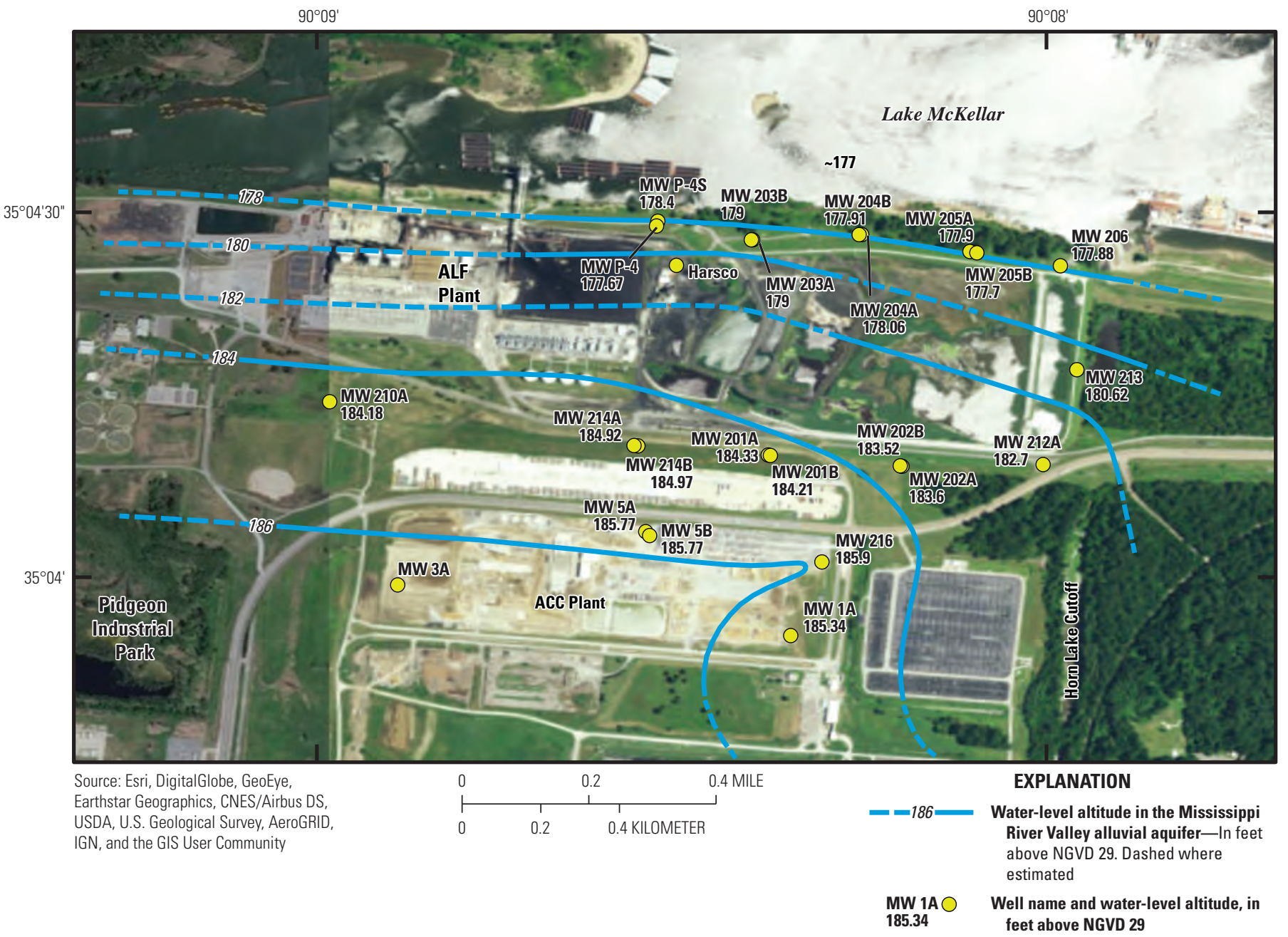

Figure 19. Late-pumping period water-level altitudes in the Mississippi River Valley alluvial aquifer and stage of Lake McKellar, Tennessee Valley Authority Allen Combined Cycle Plant aquifer test, October 3-4, 2017.

\section{Summary and Conclusions}

Prior to this study, geophysical and drillers' logs from newly installed production wells at the ACC Plant indicated that the upper Claiborne confining unit between the MRVA and Memphis aquifers was at least $45 \mathrm{ft}$ thick beneath the plant, and was thinnest in the southeastern part of the plant at the location of production well PW 1. Work conducted for the RI and for this evaluation shows that the confining unit also thins to about $26 \mathrm{ft}$ in thickness in the southeastern part of the ALF Plant, and that increasing depth to the base of the unit in this area compared to other locations in the TVA plants area indicates potential offset from faulting. A general east-southeasterly thinning of the confining unit toward the eastern margin of the Mississippi River Valley alluvial plain and the bluff along the east side of the Pidgeon Industrial Park at both TVA plants; the existence of a window in the confining unit in a similar setting west of the MLGW Davis well field, about 3 mi south of the plants; and an inferred window on President's Island, about 1 mi north of the plants; indicate a potential for leakage from the MRVA aquifer to the Memphis aquifer in the general vicinity of the TVA plants site.

Results of this evaluation provide evidence for downward leakage of water from the MRVA aquifer to the Memphis aquifer near the TVA plants site. The aquifer test and groundwater-quality sample data indicate that the effects of downward leakage of water from the MRVA aquifer are limited to the upper part of the Memphis aquifer in the area of ACC Plant production well PW 5, and possibly production well PW 3, and imply that changes in water quality in the Memphis aquifer at these locations predate any leakage induced during the test. This interpretation is further supported by the results from the second round of tritium analyses for samples collected from the production wells during the aquifer test. Slight declines in tritium concentrations in the second samples collected from production wells PW 5 and PW 3 suggest that the proportion of young water in the Memphis aquifer may have decreased during the test as the contribution of unaffected Memphis aquifer water pulled toward and withdrawn by the pumping wells increased. 
The results of the evaluation provide an update to the general conceptual model and hydrogeologic framework of the area. Downward leakage of groundwater from the MRVA aquifer to the Memphis aquifer near the MLGW Davis well field and in the TVA plants area has not been simulated using the regional MERAS groundwater-flow model because the hydrogeologic framework used to construct the model did not include windows in the confining unit between the MRVA and Memphis aquifers in these areas. The results of the aquifer test and other newly acquired hydrogeologic data are critical components needed for refining the hydrogeologic framework and for incorporation into a numerical model that produces meaningful simulations of groundwater flow and solute transport in the area.

A number of conclusions can be drawn from this evaluation. These include the following:

- The upper Claiborne confining unit is present beneath all parts of the TVA plants site investigated to date, but the confining unit thins and the base deepens in an east-southeasterly direction across the area where possible offset along one of two inferred faults may put the MRVA and Memphis aquifers in hydraulic connection.

- The aquifer-test results indicate that the MRVA and Memphis aquifers are hydraulically connected in the TVA plants area.

- The greatest drawdown from the aquifer test in the MRVA aquifer occurred in the eastern-southeastern part of the TVA plants area, in the direction of the bluff along the eastern side of the Mississippi River Valley alluvial plain, suggesting that an area of leakage exists in this general direction.

- The area of leakage appears to lie in a similar setting as the window identified about $3 \mathrm{mi}$ south of the TVA plants site and west of the MLGW Davis well field.

- Analysis of the aquifer-test results indicates that withdrawals by at least one other Memphis aquifer production well in the area appear to affect water levels in the MRVA aquifer near the TVA plants site.

- Inorganic constituent water-quality data collected from at least one of the production wells at the ACC Plant during the evaluation indicate mixing of water from the MRVA aquifer with Memphis aquifer water; similar results for the original samples collected from the production wells imply that this mixing likely pre-dates the aquifer test.
- Tritium was not detected in the ACC Plant production wells where mixing of water from the MRVA aquifer with the Memphis aquifer is not inferred based on inorganic constituent concentrations; conversely, tritium was detected in the production well where mixing of water from the two aquifers is indicated.

Along with these findings, this evaluation raises additional questions that need to be considered when planning for future data collection efforts and analysis. These questions include the following:

- Are observed offsets in the confining unit the result of faulting, erosion, or a combination of both?

- What methods can be used to better map and verify the location and extent of the window(s) in the confining unit?

- What are the lithologic and hydraulic characteristics of sediments that make up the window area(s)?

- How do the gradients between the two aquifers vary spatially and temporally around the window area(s), particularly in relation to changes in the stage of Lake McKellar?

- How can the relative proportions of young water moving from the MRVA to the Memphis aquifer and the potential effects on water quality be better quantified, and how do fluxes and mixing vary under different pumping conditions?

- How do other groundwater withdrawals from elsewhere in Shelby County affect water levels and leakage in this area?

- Does the presence of a window(s) in proximity to development on President's Island and at the Pidgeon Industrial Park increase the potential for contamination of the Memphis aquifer?

Answering these questions will provide valuable information needed to (1) better characterize the hydraulic connection between the MRVA and Memphis aquifers in the TVA plants area, (2) conduct model-based simulation of groundwater flow and solute transport in the area, and (3) increase overall understanding of the hydrogeology of the aquifer system in order to better manage and protect the groundwater resources in the Memphis area. 


\section{References}

Ackerman, D.J., 1996, Hydrology of the Mississippi River Valley alluvial aquifer, South-Central United States: U.S. Geological Survey Professional Paper 1416-D, 68 p.

Bell, E.A., and Nyman, D.J., 1968, Flow pattern and related chemical quality of ground water in the "500 foot" sand in the Memphis area, Tennessee: U.S. Geological Survey Water-Supply Paper 1853, 27 p.

Blum, M.D., Guccione, M.J., Wysocki, D.A., Robnett, P.C., and Rutledge, E.M., 2000, Late Pleistocene evolution of the lower Mississippi River Valley, southern Missouri to Arkansas, Geologic Society of America Bulletin, v. 112, p. 221-235.

Brahana, J.V., and Broshears, R.E., 2001, Hydrogeology and ground-water flow in the Memphis and Fort Pillow aquifers in the Memphis area, Tennessee: U.S. Geological Survey Water-Resources Investigations Report 89-4131, 56 p.

Carmichael, J.K., and Kingsbury, J.A., 2018, Water-level models used to estimate drawdown in 32 monitoring wells screened in the Mississippi River Valley alluvial aquifer and 4 observation wells screened in the Memphis aquifer during an aquifer test at the Tennessee Valley Authority Allen power plants, Memphis, Shelby County, Tennessee, October 2017: U.S. Geological Survey data release, https:// doi.org/10.5066/P9LSM5YU.

Charlier, T., 2017, High levels of arsenic, lead found beneath Tennessee Valley Authority plant: Commercial Appeal, published July 12, 2017, and accessed February 2018 at https://www.commercialappeal.com/story/news/2017/07/12/ high-levels-arsenic-lead-found-beneath-tennessee-valleyauthority-plant/470096001/.

Clark, B.R., and Hart, R.M., 2009, The Mississippi Embayment Regional Aquifer Study (MERAS): Documentation of a groundwater-flow model constructed to assess water availability in the Mississippi embayment: U.S. Geological Survey Scientific Investigations Report 2009-5172, 61 p.

Criner, J.H., Sun, P-C.P., and Nyman, D.J., 1964, Hydrology of the aquifer systems in the Memphis area, Tennessee: U.S. Geological Survey Water-Supply Paper 1779-O, 54 p.

Ferreira, L.A., Larsen, D., and Gallo, H.G., 2013, Sedimentology and stratigraphy of the Eocene Cockfield Formation at Meeman-Shelby Forest State Park, western Tennessee: Geological Society of America Abstracts with Program, v. 45 , no. 7 , p. 591 .
Gentry, R., McKay, L., Thonnard, N., Anderson, J.L., Larsen, D., Carmichael, J.K., and Solomon, K., 2006, Novel techniques for investigating recharge to the Memphis aquifer: Denver, American Water Works Association Report no. 91137, 97 p.

Gentry, R.W., Ku, T.-L., Luo, S., Todd, V., Larsen, D., and McCarthy, J., 2005, Resolving aquifer behavior near a focused recharge feature based upon synoptic wellfield hydrogeochemical tracer results: Journal of Hydrology, accessed February 2018 at https://doi:10.1016/j.jhydrol.2005.09.011.

Graham, D.D., and Parks, W.S., 1986, Potential for leakage among principal aquifers in the Memphis area, Tennessee: U.S. Geological Survey Water-Resources Investigations Report 85-4295, 46 p., accessed February 2018 at https:// pubs.er.usgs.gov/publication/wri854295.

Grimley, D.A., Larsen, D., Kaplan, S.W., Yansa, C.H., Curry, B.B., and Oches, E.A., 2009, A multi-proxy palaeoecological and palaeoclimatic record within full glacial lacustrine deposits, western Tennessee, USA: Journal of Quaternary Science, v. 24, no. 8, p. 960-981.

Halford, K., Garcia, C.A., Fenelon, J., and Mirus, B., 2012, Advanced methods for modeling water-levels and estimating drawdowns with SeriesSEE, an Excel Add-In, (ver. 1.1, July, 2016): U.S. Geological Survey Techniques and Methods 4-F4, 28 p., accessed February 2018 at https://dx.doi. org/10.3133/tm4F4.

Hao, Y., Magnani, M.B., McIntosh, K., Waldron, B., and Guo, L., 2013, Quaternary deformation along the MeemanShelby Fault near Memphis, Tennessee, imaged by high-resolution marine and land seismic reflection profiles: Tectonics, v. 32, p. 501-515, accessed February 2018 at https:// doi:10.1002/tect.20042.

Haugh, C.J., 2016, Evaluation of effects of groundwater withdrawals at the proposed Allen combined-cycle combustion turbine plant, Shelby County, Tennessee: U.S. Geological Survey Scientific Investigations Report 2016-5072, 8 p., accessed February 2018 at https://pubs.er.usgs.gov/ publication/sir20165072.

Ivey, S.S., Gentry, R., Larsen, D., and Anderson, J., 2008, 2. Inverse application of age- distribution modeling using environmental tracers ${ }^{3} \mathrm{H} /{ }^{3} \mathrm{He}$ : MLGW Sheahan well field, Memphis, TN: Journal of Hydrologic Engineering, v. 13, p. 1011-1020. 
Kingsbury, J.A., 1996, Altitude of the potentiometric surfaces, September 1995, and historical water-level changes in the Memphis and Fort Pillow aquifers in the Memphis area, Tennessee: U.S. Geological Survey Water-Resources Investigation 96-4278, 1 sheet.

Kingsbury, J.A., Barlow, J.R.B., Katz, B.G., Welch, H.L., Tollett, R.W., and Fahlquist, L.S., 2014, The quality of our Nation's waters-Water quality in the Mississippi embayment-Texas coastal uplands aquifer system and Mississippi River Valley alluvial aquifer, south-central United States, 1994-2008: U.S. Geological Survey Circular 1356, $72 \mathrm{p}$.

Kingsbury, J.A., and Parks, W.S., 1993, Hydrogeology of the principal aquifers and relation of faults to interaquifer leakage in the Memphis area, Tennessee: U.S. Geological Survey Water-Resources Investigations Report 93-4075, 18 p.

Koban, J., Larsen, D., and Ivey, S., 2011, Resolving the source and mixing proportions of modern leakage to the Memphis aquifer in a municipal well field using geochemical and ${ }^{3} \mathrm{H} /{ }^{3} \mathrm{He}$ data, Memphis, Tennessee, USA: Environmental Earth Sciences, v. 66, no. 1, p. 295-310, accessed February 2018 at https://doi.org/10.1007/s12665-011-1239-x.

Koban, J.M., 2017, Mississippi River Islands and their potential to affect nitrogen cycling near Memphis, Tennessee, USA: University of Memphis, unpublished Ph.D. dissertation.

Koontz, M.B., Pezeshki, S.R., and DeLaune, R.D., 2014, Nutrient dynamics in a restored wetland: Communications in Soil Science and Plant Analysis, v. 54, no. 5, p. 609-623, accessed February 2018 at https://doi.org/10.1080/00103624.2013.874020.

Kresse, T.M., and Fazio, J.A., 2003, Occurrence of arsenic in ground waters of Arkansas and implications for source and release mechanisms: Arkansas Department of Environmental Quality Water Quality Report WQ03-03-01, 35 p.

Krinitzsky, E.L., and Wire, J.C., 1964, Ground water in the alluvium of the Lower Mississippi Valley (upper and central areas): U.S. Army Engineer Waterways Experiment Station Technical Report no. 3-658 (2 v.), 100 p.

Larsen, D., and Brock, C.F., 2014, Sedimentology and petrology of the Eocene Memphis Sand and younger terrace deposits in surface exposures of western Tennessee: Southeastern Geology, v. 50, no. 4, p. 193-214.

Larsen, D., Gentry, R.W., and Solomon, D.K., 2003, The geochemistry and mixing of leakage in a semi-confined aquifer at a municipal well field: Applied Geochemistry, v. 18, p. 1043-1063.
Larsen, D., Morat, J., Waldron, B., Ivey, S., and Anderson, J., 2013, Stream loss contributions to a municipal water supply aquifer, Memphis, Tennessee: Environmental and Engineering Geoscience, v. 19, no. 3, p. 265-287.

Larsen, D., Waldron, B., Schoefernacker, S., Gallo, H., Koban, J., and Bradshaw, E., 2016, Application of environmental tracers in the Memphis aquifer and implication for sustainability of groundwater resources in the Memphis metropolitan area, Tennessee: Journal of Contemporary Water Research and Education, v. 159, p. 78-104.

Lloyd, O.B., and Lyke, W.L., 1995, Ground water atlas of the United States: Segment 10, Illinois, Indiana, Kentucky, Ohio, Tennessee: U.S. Geological Survey Hydrologic Atlas $730-\mathrm{K}, 30 \mathrm{p}$.

Martin, R.V., and Van Arsdale, R.B., 2017, Stratigraphy and structure of the Eocene Memphis Sand above the eastern margin of the Reelfoot rift in Tennessee, Mississippi, and Arkansas, USA: Bulletin of the Geological Society of America, v. 129, p. 970-996, accessed February 2018 at https://doi.org/10.1130/B31439.1.

Moore, G.K., and Brown, D.L., 1969, Stratigraphy of the Fort Pillow test well, Lauderdale County, Tennessee: Tennessee Division of Geology Report of Investigations 26.

Newcome, Roy, Jr., 1971, Results of aquifer tests in Mississippi: Mississippi Board of Water Commissioners Bulletin71-2, $44 \mathrm{p}$.

Parks, W.S., 1990, Hydrogeology and preliminary assessment of the potential for contamination of the Memphis aquifer in the Memphis area, Tennessee: U.S. Geological Survey Water-Resources Investigations Report 90-4092, 39 p., accessed February 2018 at https://pubs.er.usgs.gov/ publication/wri904092.

Parks, W.S., and Carmichael, J.K., 1990a, Geology and ground-water resources of the Memphis Sand in western Tennessee: U.S. Geological Survey Water-Resources Investigations Report 88-4182, 30 p.

Parks, W.S., and Carmichael, J.K., 1990b, Geology and ground-water resources of the Cockfield Formation in western Tennessee: U.S. Geological Survey Water-Resources Investigations Report 88-4181, 17 p.

Parks, W.S., and Lounsbury, R.W., 1976, Summary of some current and possible future environmental problems related to geology and hydrology at Memphis, Tennessee: U.S. Geological Survey Water-Resources Investigations Report 4-76, 34 p. 
Parks, W.S., and Mirecki, J.E., 1992, Hydrogeology, groundwater quality, and potential for water-supply contamination near the Shelby County landfill in Memphis, Tennessee: U.S. Geological Survey Water-Resources Investigations Report 91-4173, 79 p., accessed February 2018 at https:// pubs.er.usgs.gov/publication/wri914173.

Parks, W.S., Mirecki, J.E., and Kingsbury, J.A., 1995, Hydrogeology, ground-water quality, and source of ground water causing water-quality changes in the Davis well field at Memphis, Tennessee: U.S. Geological Survey WaterResources Investigations Report 94-4212, 58 p., accessed February 2018 at http://pubs.er.usgs.gov/usgspubs/wri/ wri944212.

Rittenour, T.M., Blum, M.D., and Goble, R.J., 2007, Fluvial evolution of the lower Mississippi River valley during the last 100 k.y. glacial cycle: Response to glaciation and sealevel change: Bulletin of the Geologic Society of America, v. 119, p. 586-608, accessed February 2018 at https://doi. org/10.1130/B25934.1.

Robinson, J.A., and Brooks, J.M., 2010, Public water-supply systems and associated water use in Tennessee, 2005: U.S. Geological Survey Open-File Report 2010-1226, 100 p., accessed February 2018 at https://pubs.usgs.gov/ of/2010/1226/.

Robinson, J.L., Carmichael, J.K., Halford, K.J., and Ladd, D.E., 1997, Hydrogeologic framework and simulation of ground-water flow and travel time in the shallow aquifer system in the area of Naval Support Activity Memphis, Millington, Tennessee: U.S. Geological Survey WaterResources Investigations Report 97-4228, 56 p.
Tye, R.S., and Coleman, J.M., 1989, Depositional processes and stratigraphy of fluvially dominated lacustrine deltas: Mississippi delta plain: Journal of Sedimentary Petrology, v. 59, p. 973-996.

U.S. Environmental Protection Agency, 2018, National Primary Drinking Water Regulations, accessed February 28, 2018, at https://www.epa.gov/ground-water-and-drinkingwater/national-primary-drinking-water-regulations.

U.S. Geological Survey, 2018, USGS Water Data for the Nation: U.S. Geological Survey National Water Information System database, accessed February 14, 2018, at https://doi. org/10.5066/F7P55KJN.

Van Arsdale, R.B., Bresnahan, R.P., McCallister, N.S., and Waldron, B., 2007, The Upland Complex of the central Mississippi River valley: Its origin, denudation, and possible role in reactivation of the New Madrid seismic zone, in Stein, S., and Mazzotti, S., eds., Continental intraplate earthquakes: Science, hazard, and policy issues: Geological Society of America Special Paper 425, p. 177-192.

Van Arsdale, R., and Cupples, W., 2013, Late Pliocene and Quaternary deformation of the Reelfoot rift: Geosphere, v. 9, p. 1819-1831, accessed February 2018 at https://doi. org/10.1130/GES00906.1.

Ward, A., Counts, R., Van Arsdale, R., Larsen, D., and Mahan, S., 2017, Quaternary displacement rates on the MeemanShelby Fault and Joiner ridge horst, eastern Arkansas: Results from coring Mississippi River alluvium: Seismological Research Letters, v. 88, no. 2A, accessed February 2018 at https://doi.org/10.1785/0220160171. 


\section{Appendix 1. SeriesSEE Water-Level Model Hydrographs-Allen Combined Cycle Plant Monitoring Wells}

These Graphic Interchange Format (.gif) images show the synthetic (modeled) data that were created by the SeriesSEE models from the continuous water-level data collected during the aquifer test. The residuals between the synthetic and measured data are shown as the differences. [MW, monitoring well; ft, feet; RMS, root-mean-square error; discharge, pumping rate; Q ALL.gpm, cumulative pumping rate by the TVA ACC Plant production wells for the test]
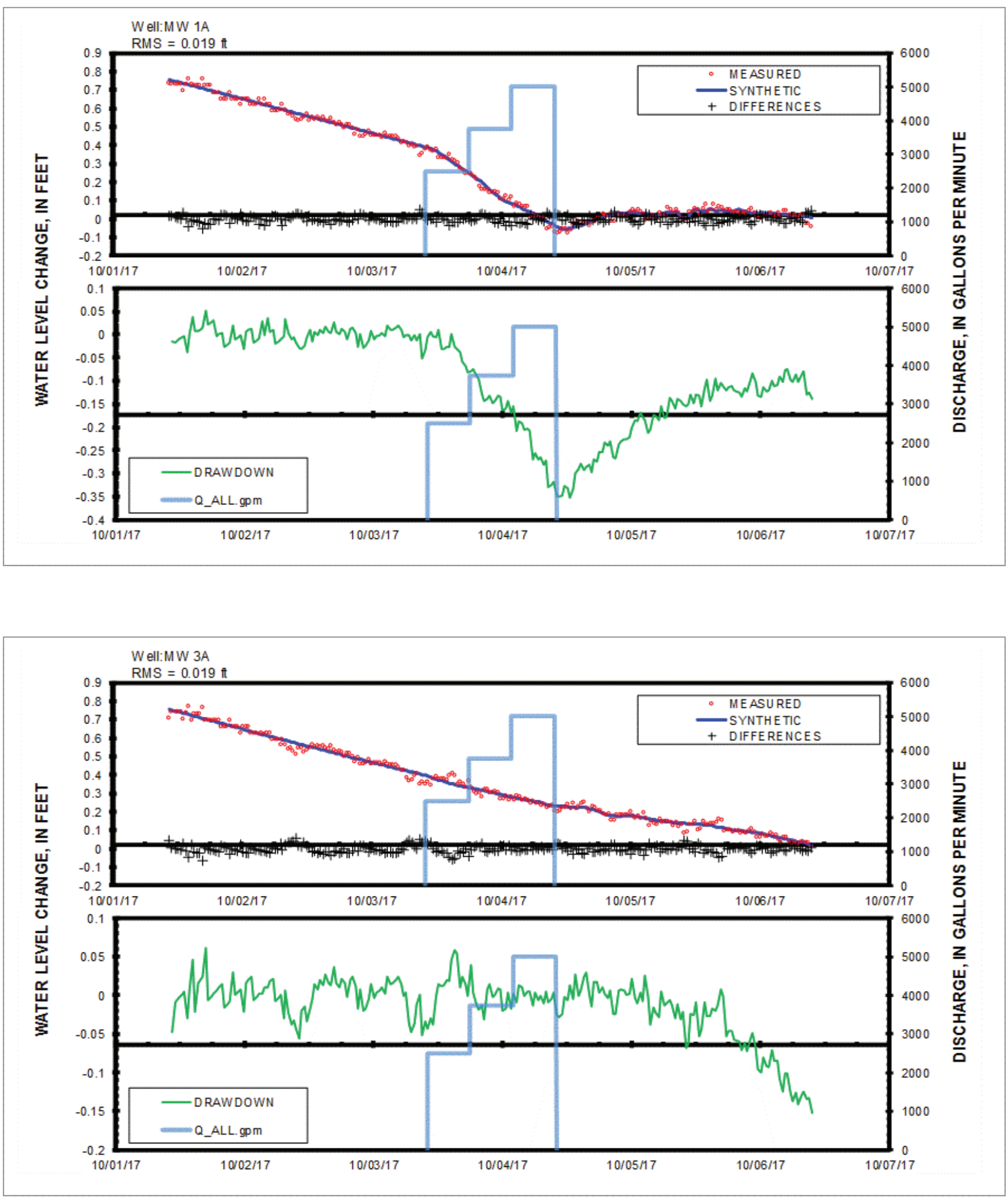

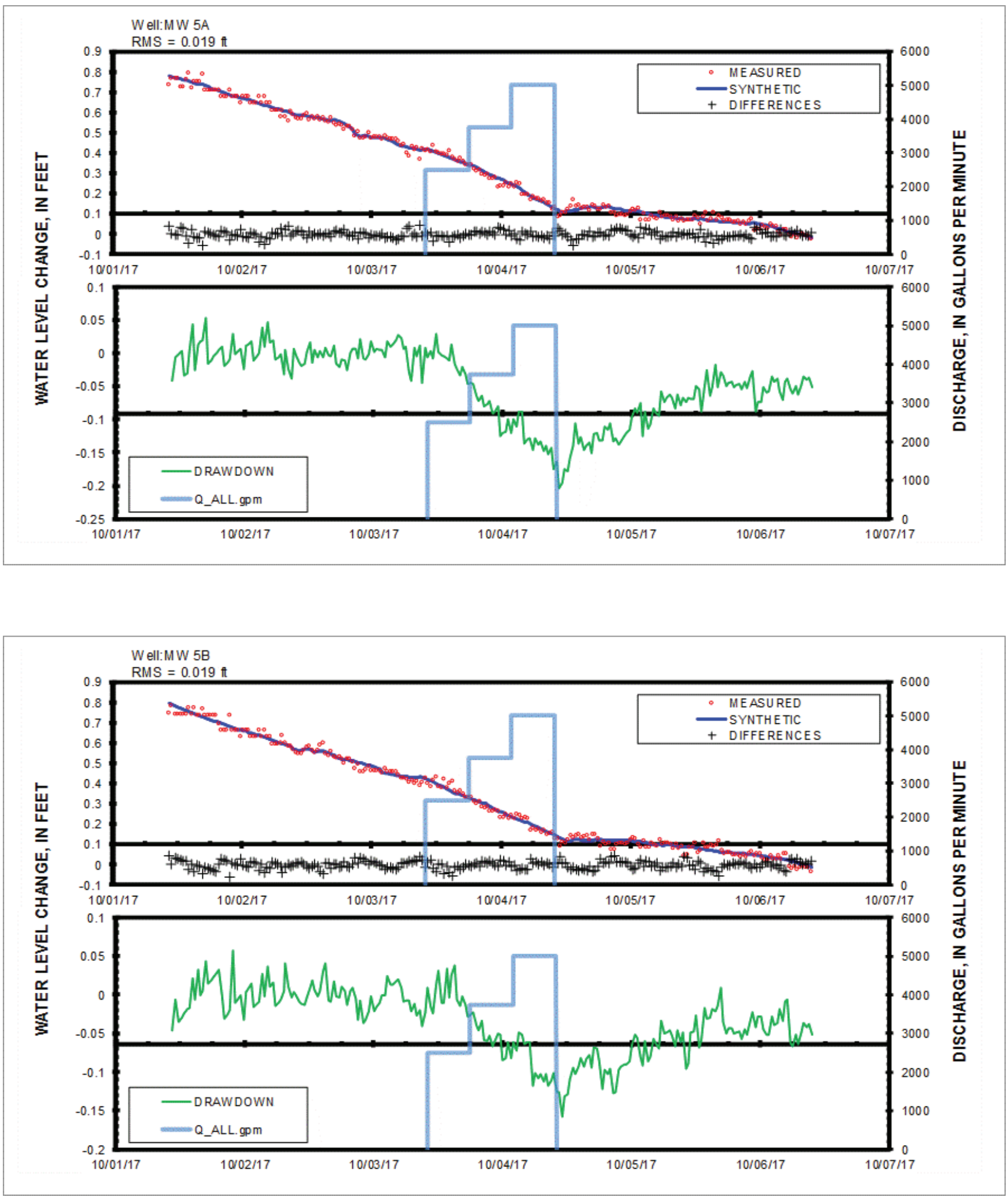


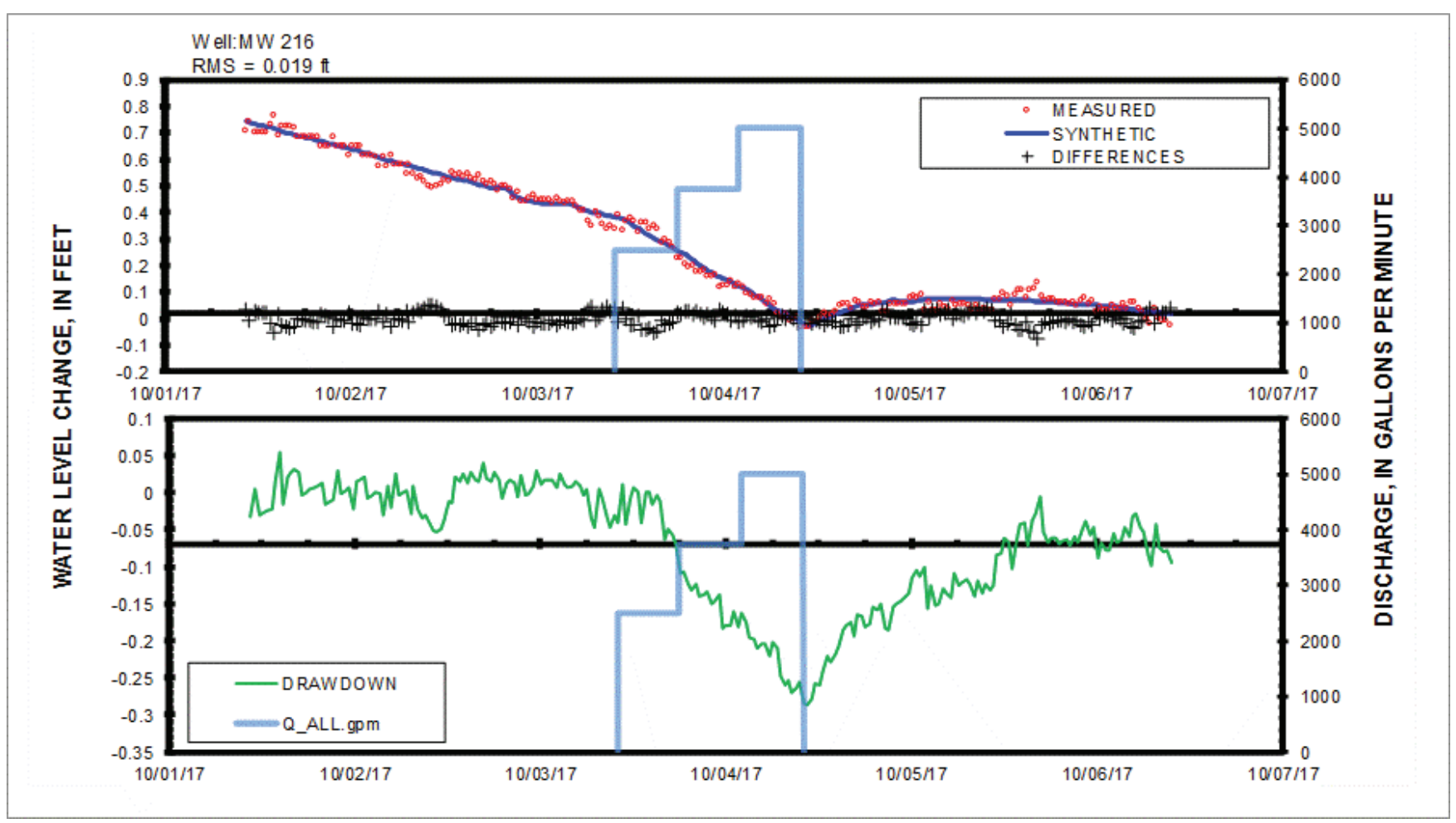




\section{Appendix 2. SeriesSEE Water-Level Model Hydrographs—Allen Fossil Plant Monitoring Wells}

These Graphic Interchange Format (.gif) images show the synthetic (modeled) data that were created by the SeriesSEE models from the continuous water-level data collected during the aquifer test. The residuals between the synthetic and measured data are shown as the differences. [MW, monitoring well; ft, feet; RMS, root-mean-square error; discharge, pumping rate; Q ALL.gpm, cumulative pumping rate by the TVA ACC Plant production wells for the test]
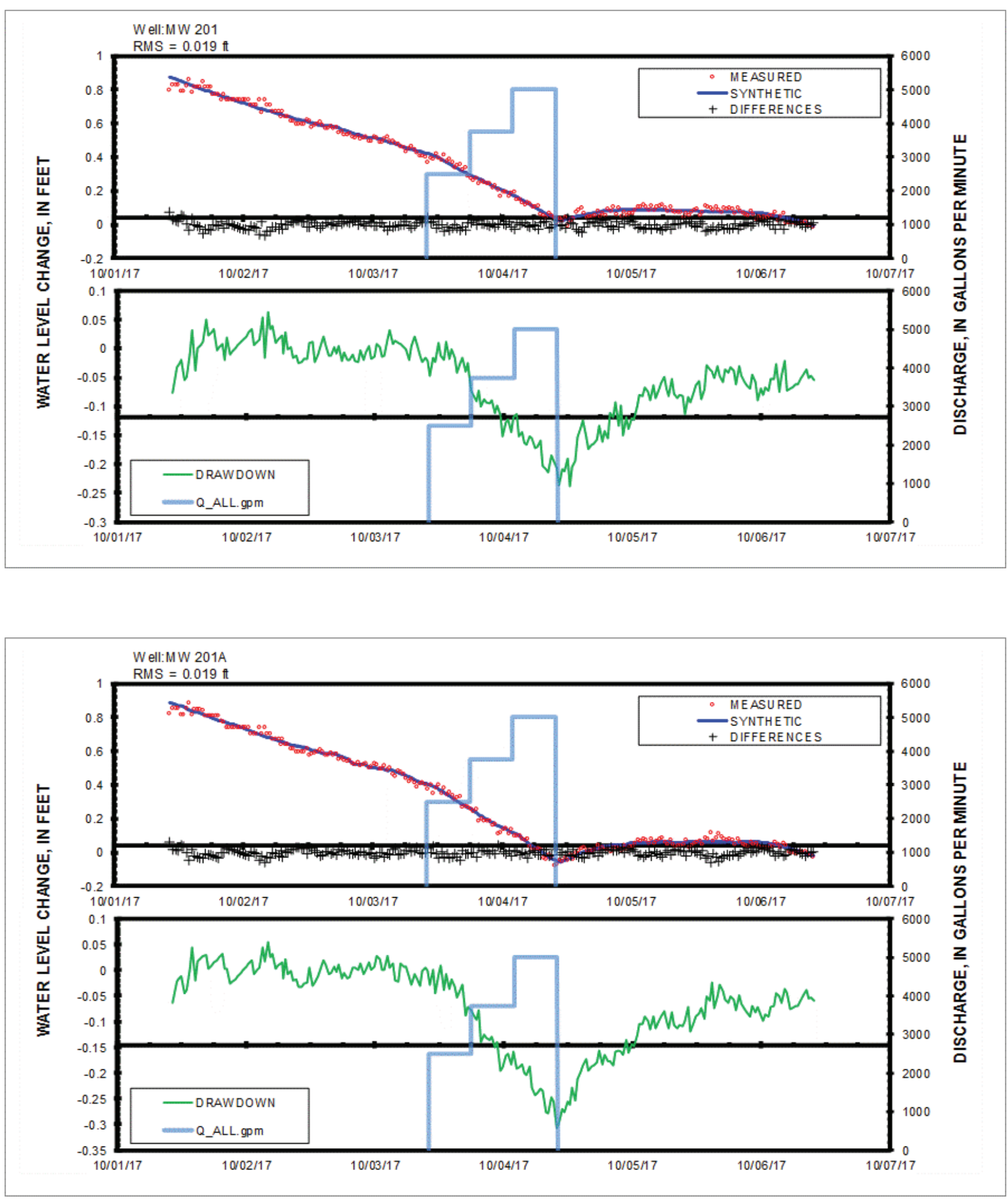

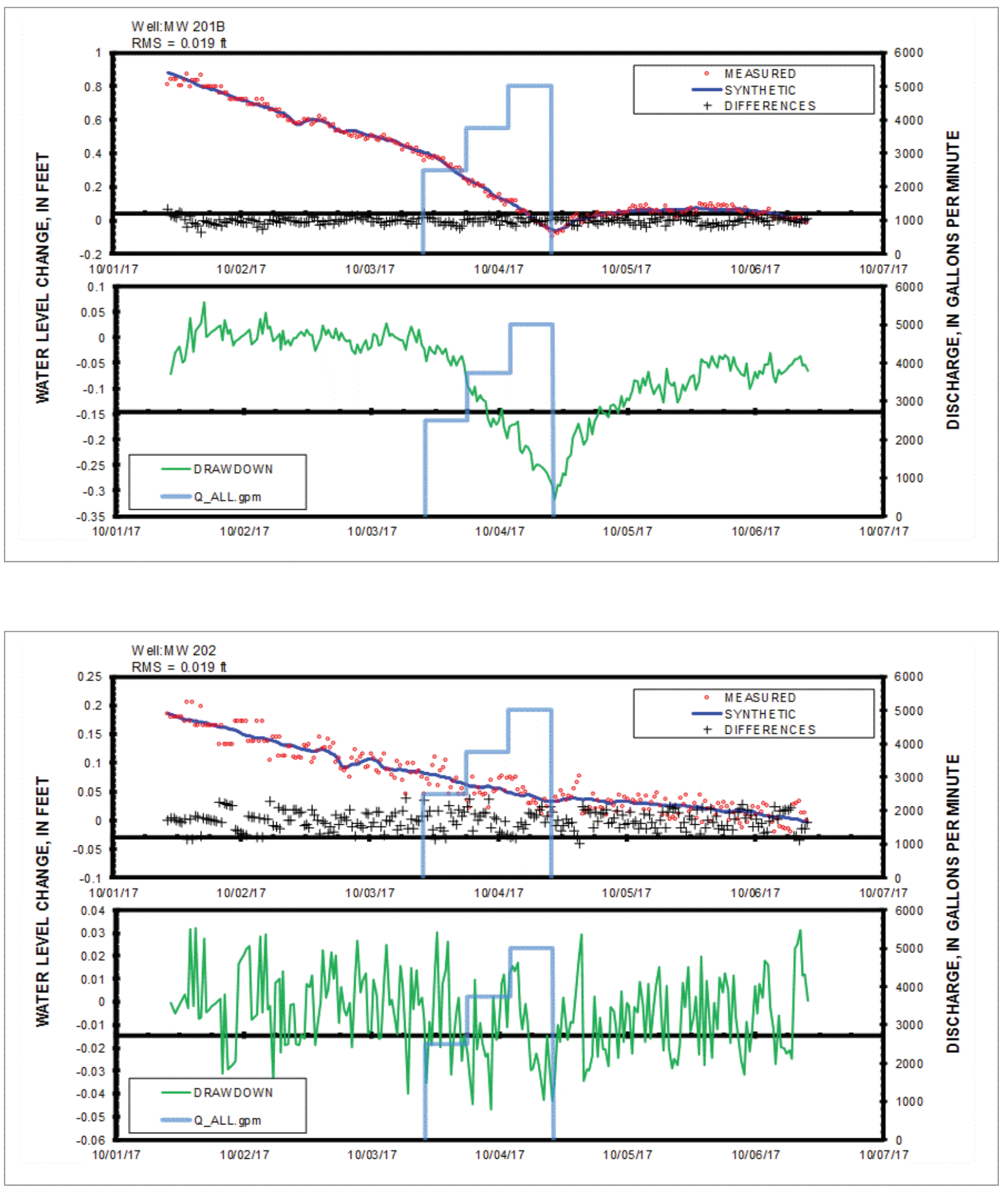

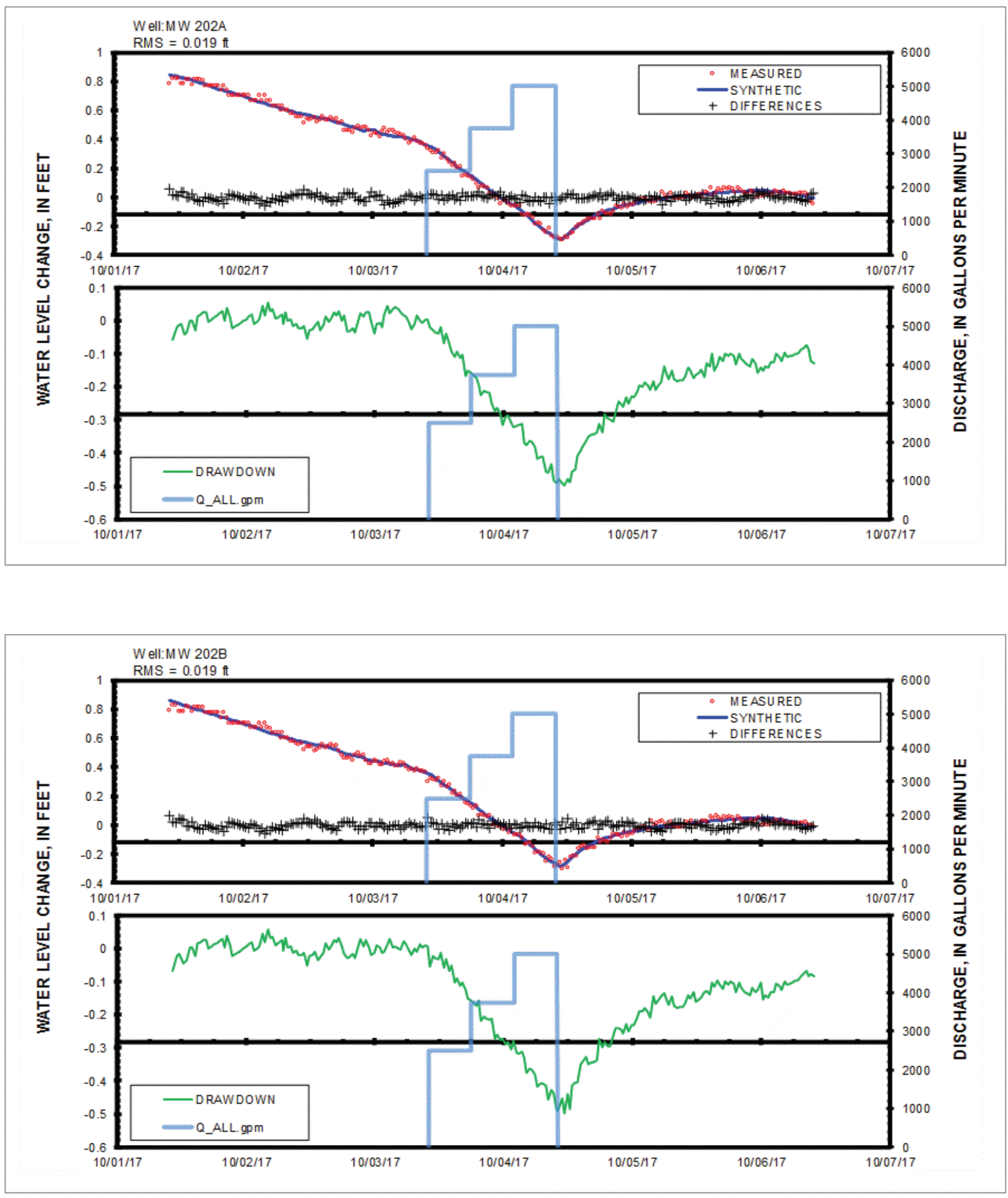

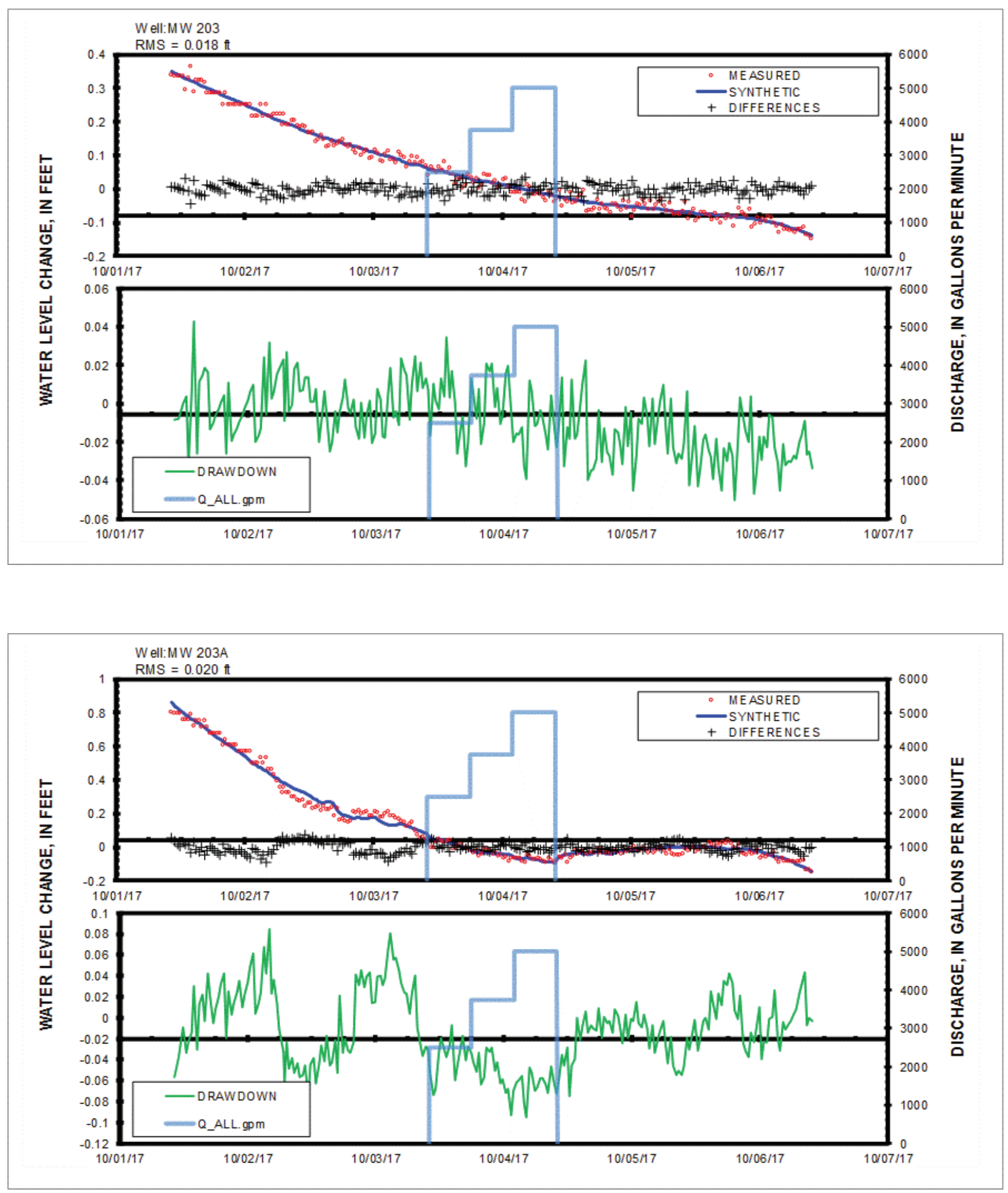

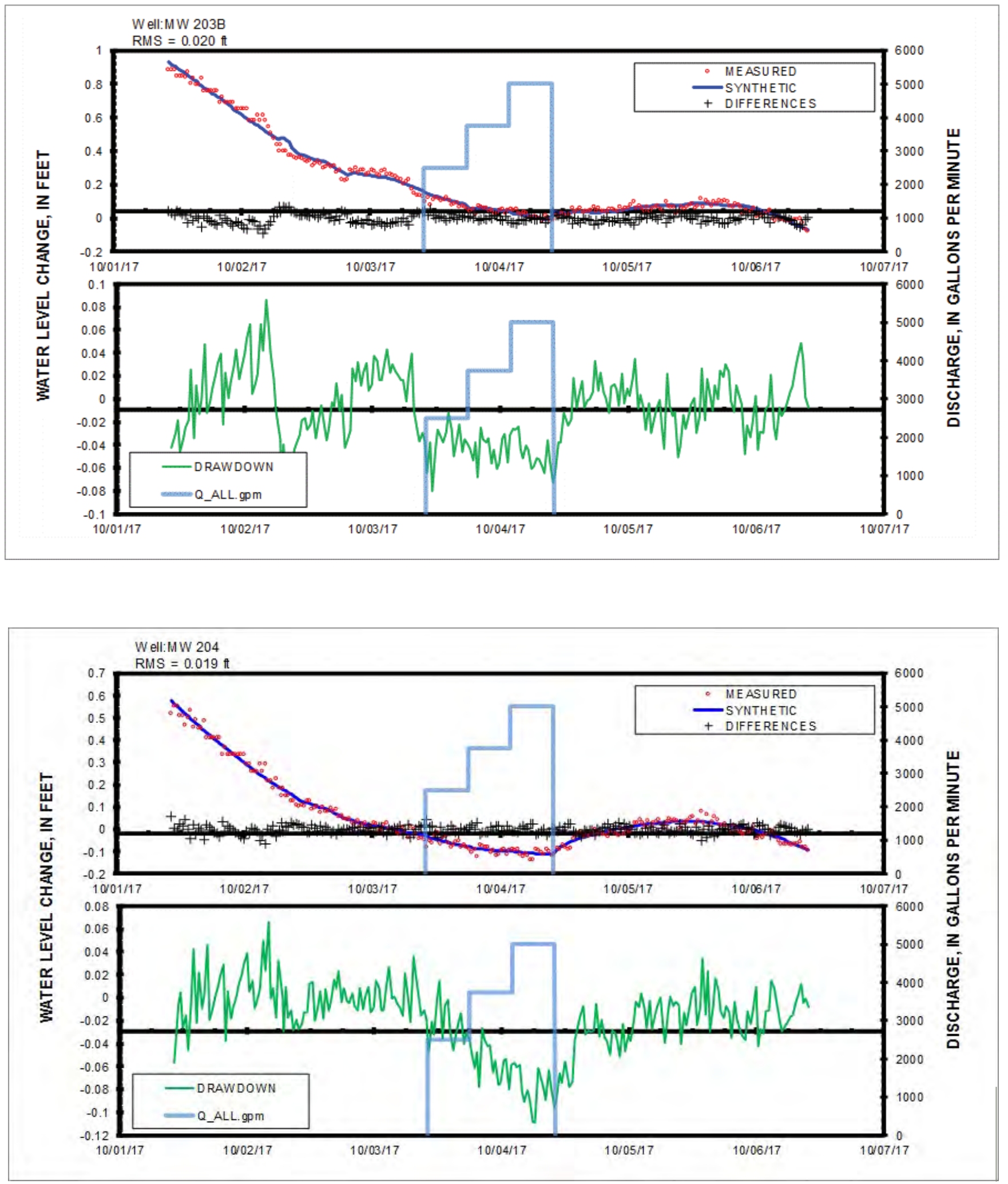

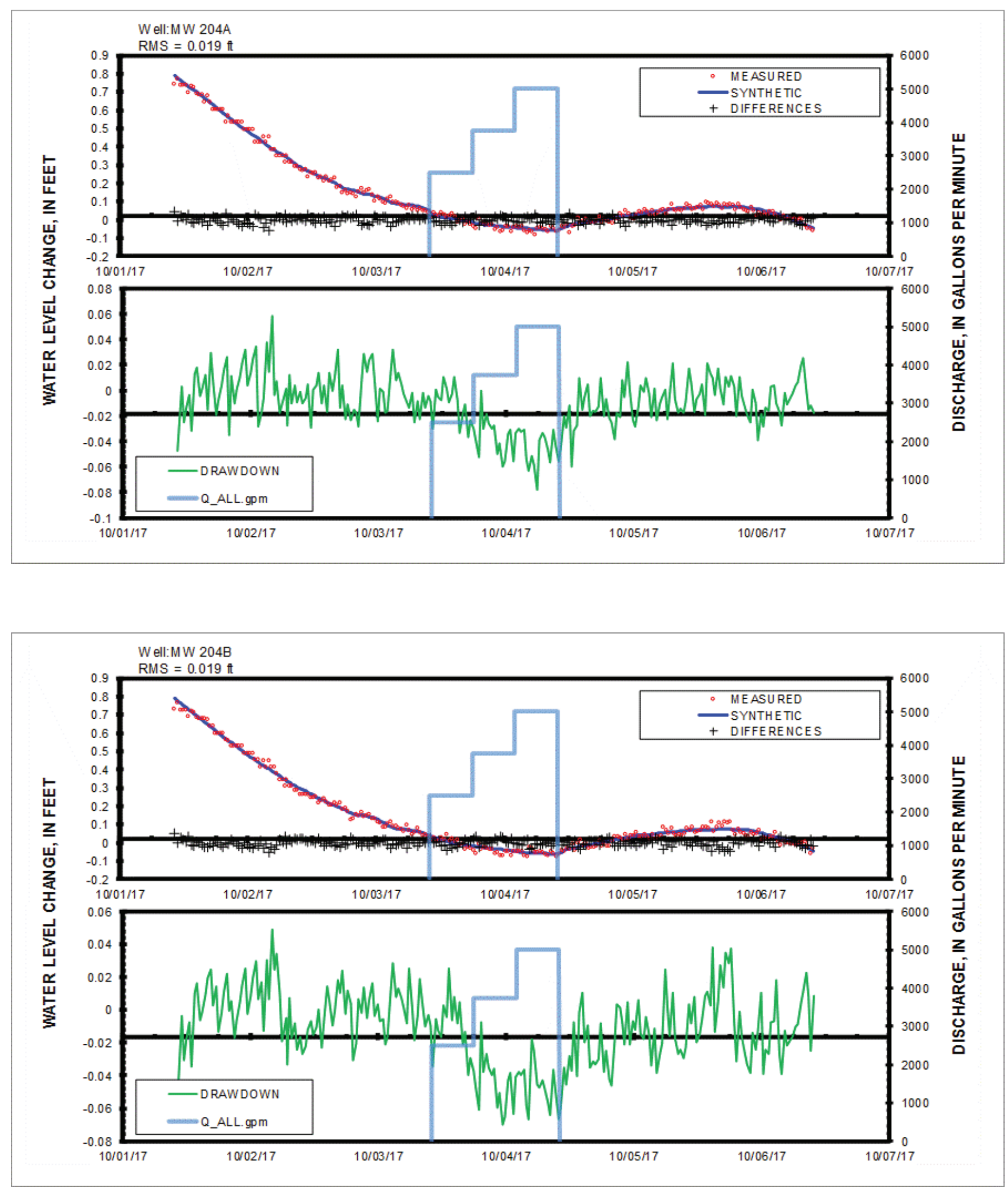

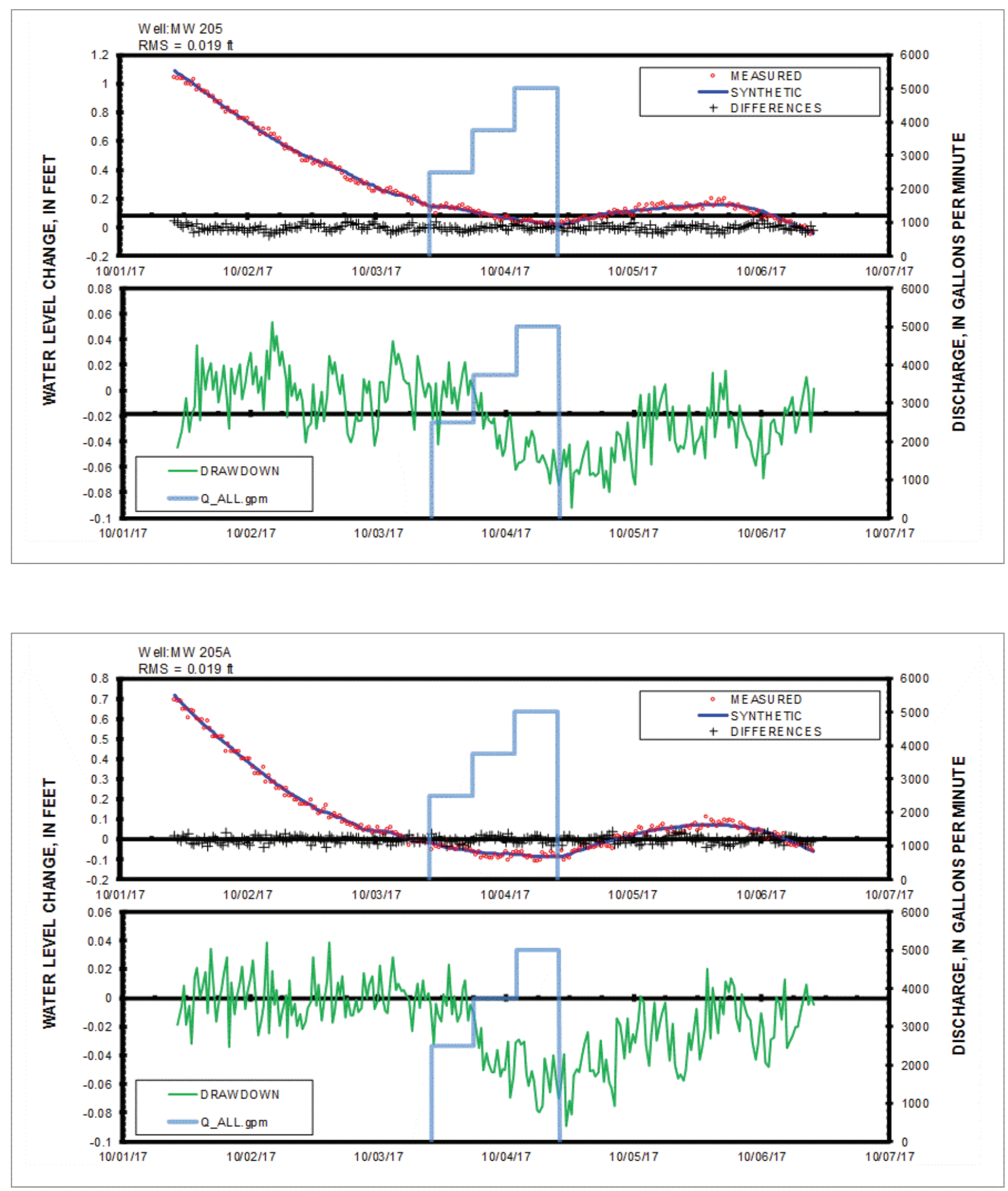

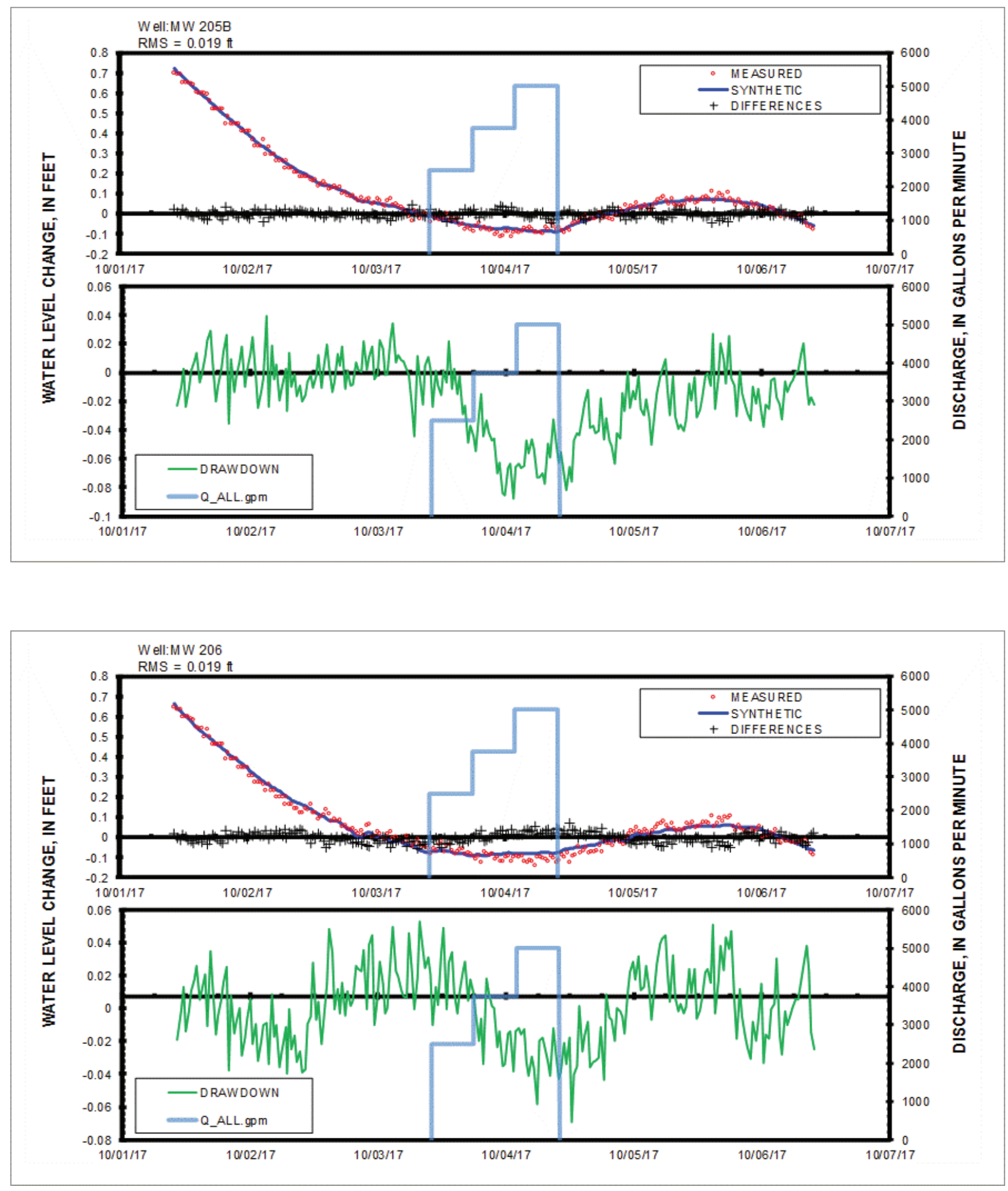

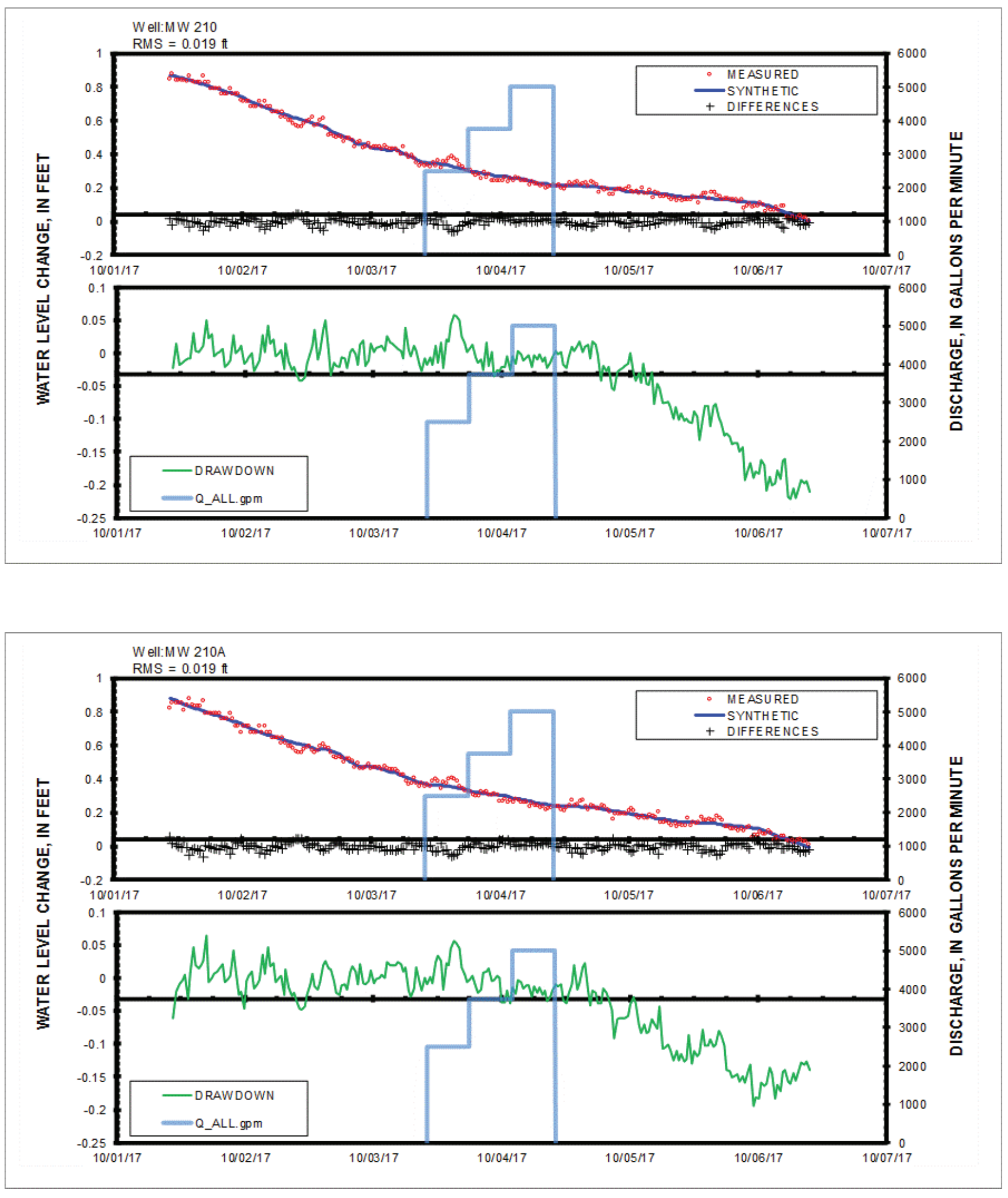

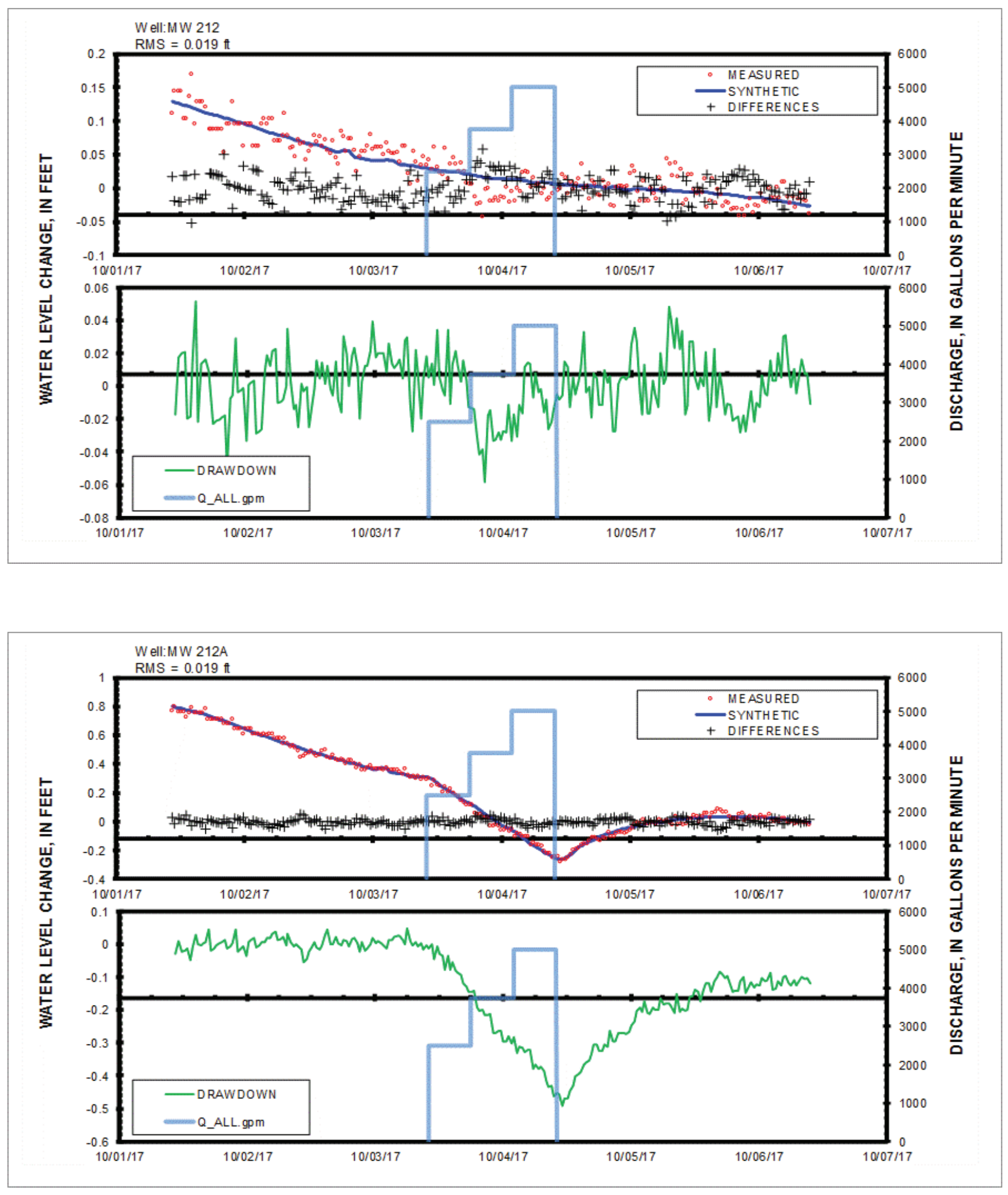

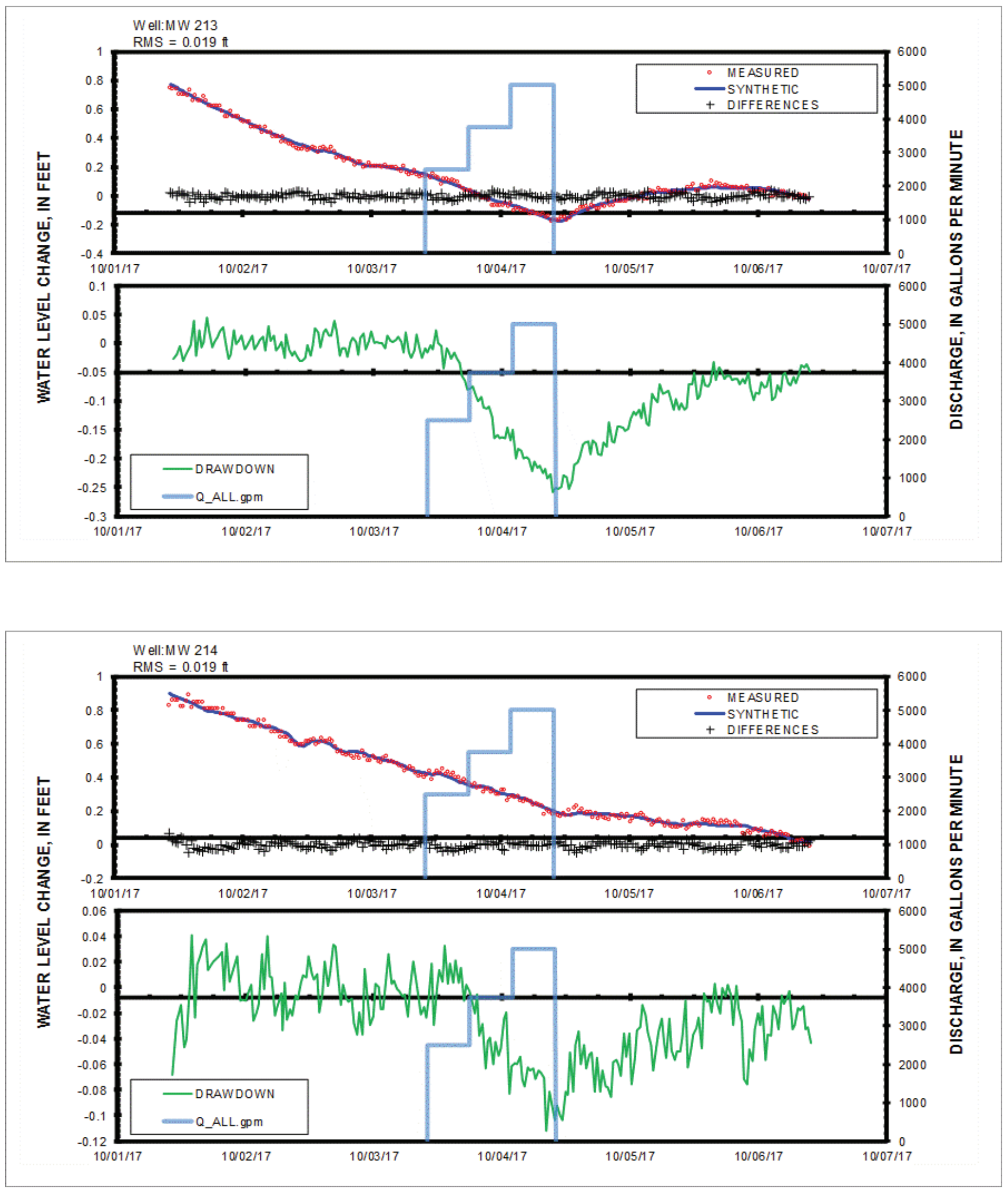

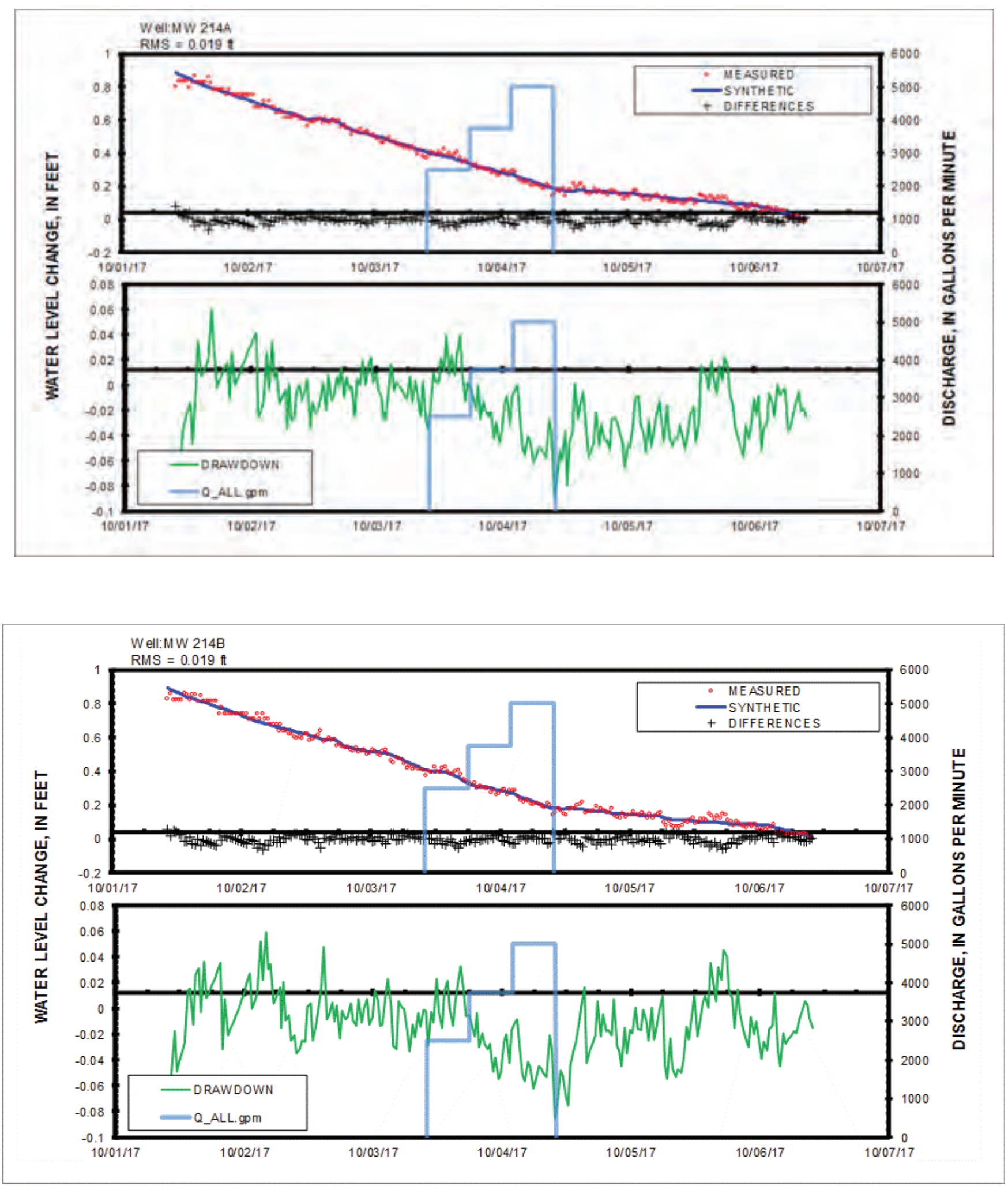

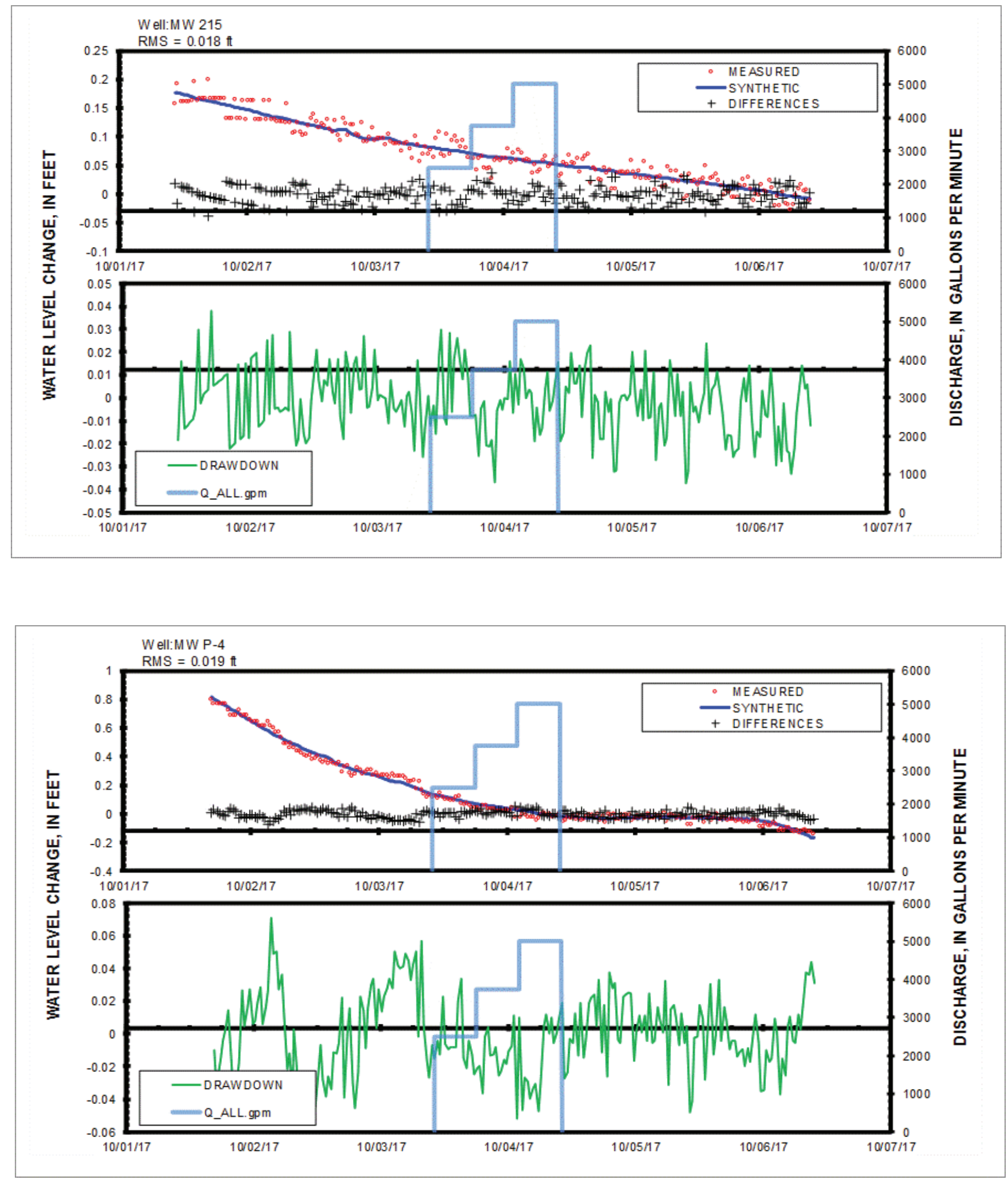


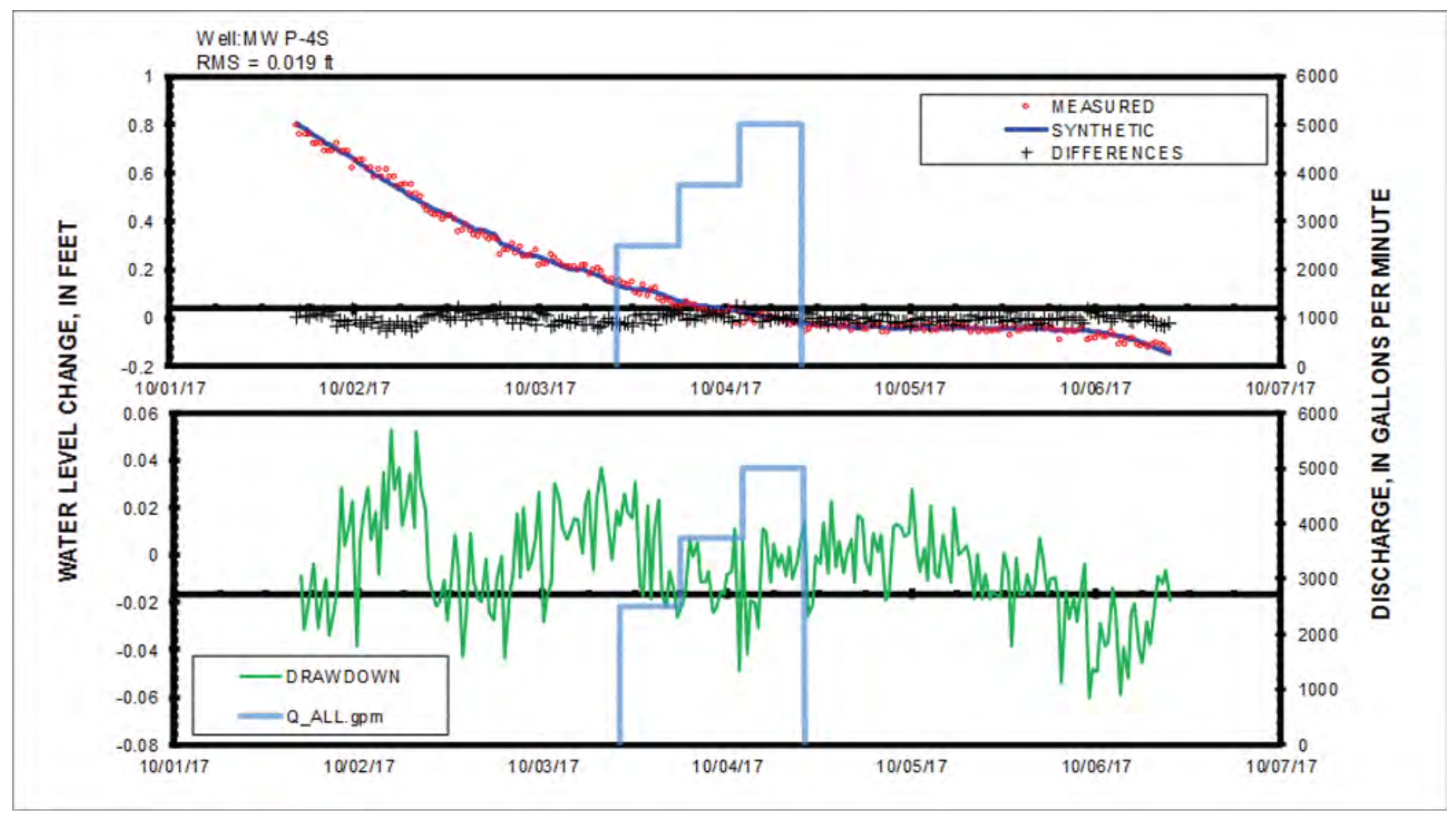




\section{Appendix 3. SeriesSEE Water-Level Model Hydrographs-Memphis Aquifer Observation Wells}

These Graphic Interchange Format (.gif) images show the synthetic (modeled) data that were created by the SeriesSEE models from the continuous or periodic (well PW 2) water-level data collected during the aquifer test. The residuals between the synthetic and measured data are shown as the differences. [MW, monitoring well; ft, feet; RMS, root-mean-square error; discharge, pumping rate; Q_ALL.gpm, cumulative pumping rate by the TVA ACC Plant production wells for the test]
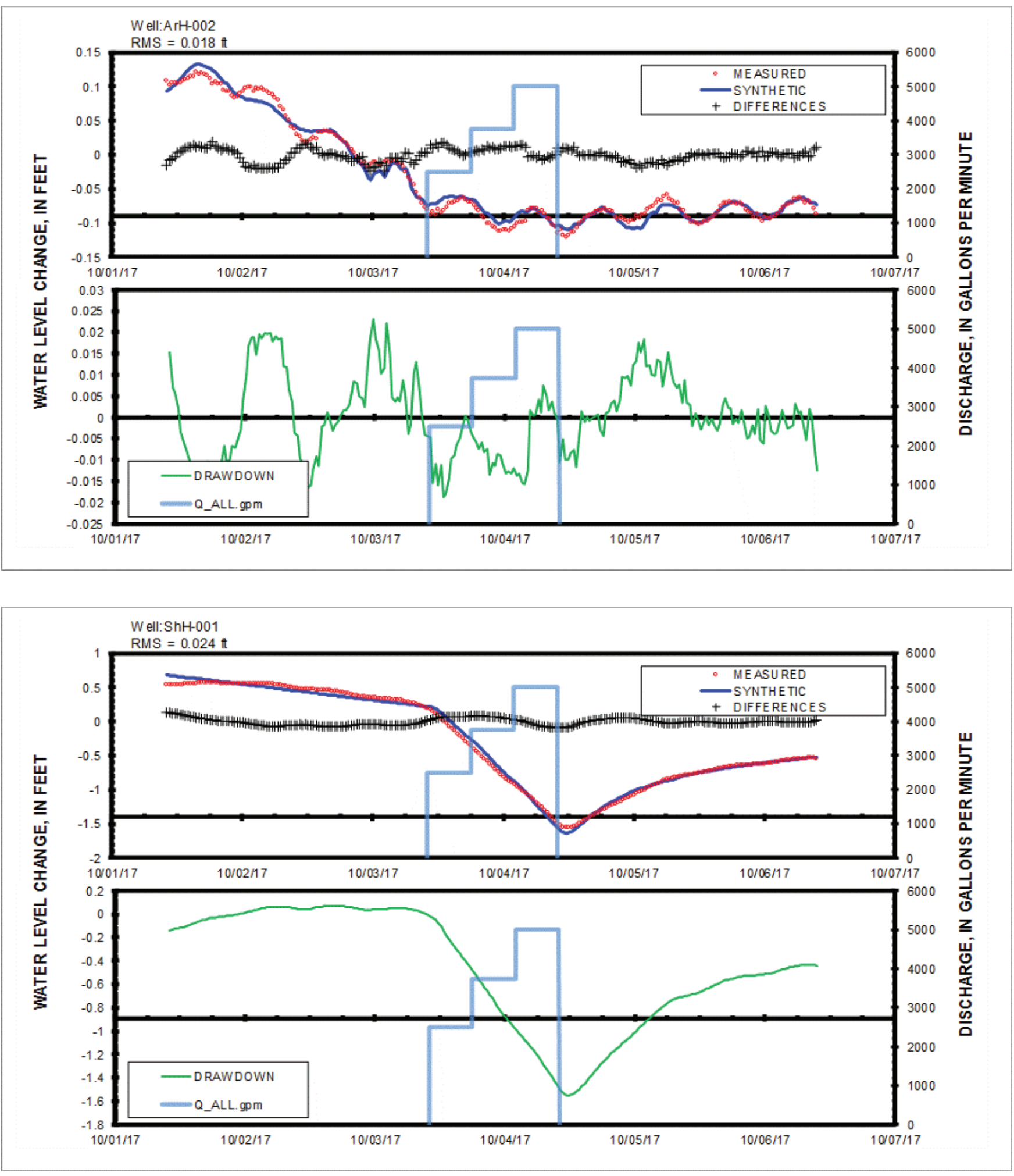

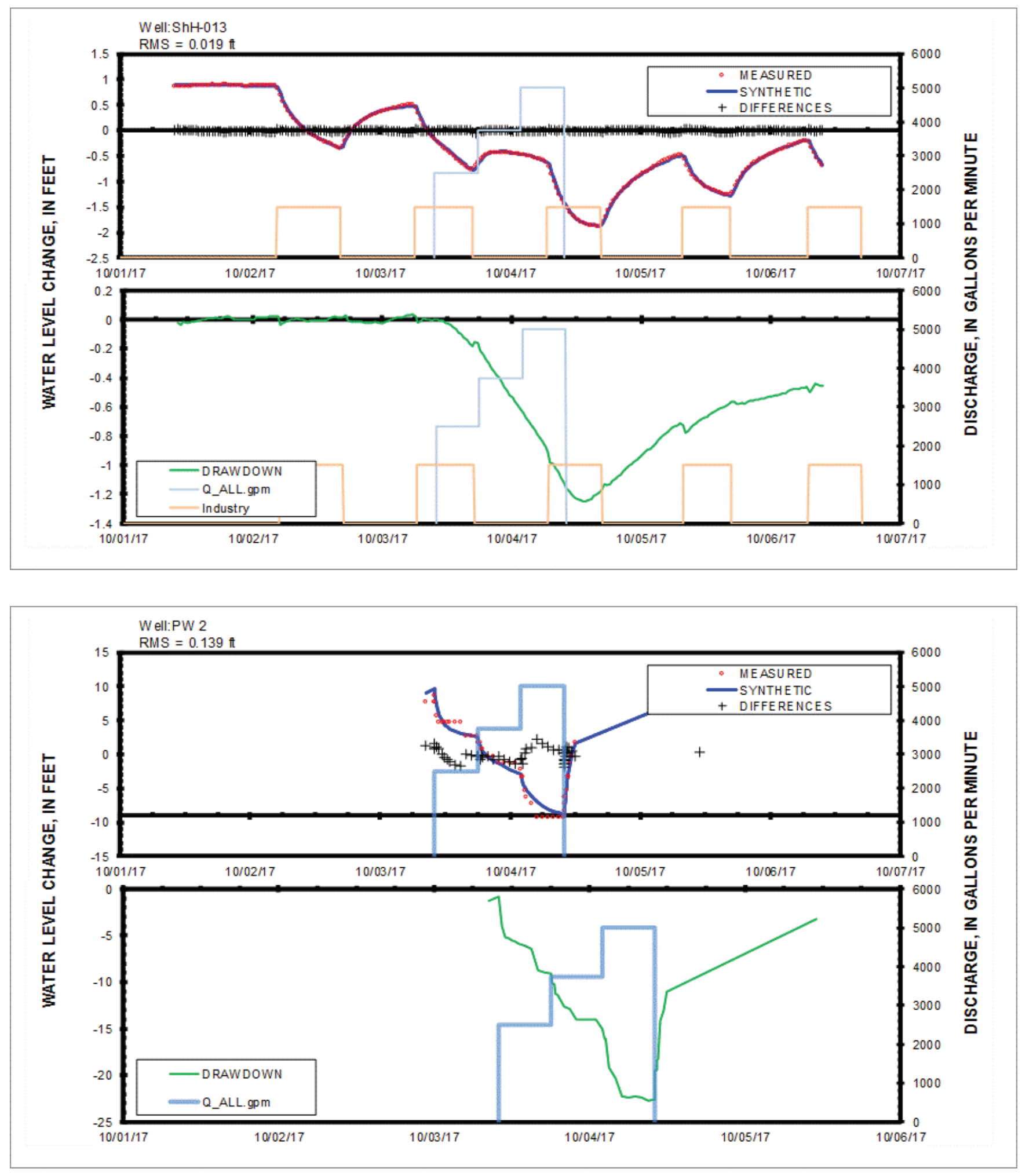
Publishing support provided by Lafayette Publishing Service Center

For more information concerning this publication, contact Director, USGS Lower Mississippi-Gulf Water Science Center-Tennessee (LMGWSC)

640 Grassmere Park, Suite 100

Nashville, TN 37211

(615) 837-4700

Or visit the LMGWSC website at https://www.usgs.gov/centers/lmg-water/ 


\section{这}

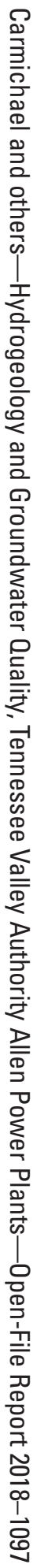

